\title{
Identifying Developmental Dyslexia in 9 Korean Elementary School Students at Risk for Dyslexia
}

\author{
Eun Ju Lee, ${ }^{a}$ Young Tae Kim ${ }^{\mathrm{b}}$ \\ ${ }^{a}$ The Special Education Research Institute (SERI), Ewha Womans University, Seoul, Korea \\ ${ }^{b}$ Department of Communication Disorders, Ewha Womans University, Seoul, Korea
}

Correspondence: Eun Ju Lee, PhD

The Special Education Research Institute (SERI), Ewha Womans University, 52 Ewhayeodae-gil, Seodaemun-gu, Seoul 03760, Korea

Tel: +82-10-7335-1953

Fax: +82-2-3277-2679

E-mail: imfedra@naver.com

Received: July 3, 2020

Revised: July 25, 2020

Accepted: July 25, 2020

This study was supported by the Ministry of Education of the Republic of Korea and the National Research Foundation of Korea (No. NRF2018S1A3A2075274)

\begin{abstract}
Objectives: The purpose of this case profile study is to discuss the diagnosis model of dyslexia, the characteristics of comorbidity, and how the results of various reading-related measurements can be linked to interpret the diagnosis. Methods: Nine elementary school students with suspected dyslexia ( $\mathrm{N}=9$ ) were diagnosed through existing diagnostic models the differences between the models were examined. The results of the dyslexic diagnosis, along with comorbidities were analyzed using corresponding analysis. Finally, profile analyses of the reading-related variables were conducted for the dyslexic group classified through the corresponding analysis. Results: As a result of the first section of this analysis, the criteria for diagnosing dyslexia differed in the three diagnostic models, so the nine suspected dyslexics were classified differently depending on the diagnostic model. As a result of the second portion of this analysis, it was possible to classify the dyslexic group according to comorbidities such as DLD, ADHD, SSD, TOT. And the result of the third section of this analysis showed that decoding, reading comprehension, reading fluency, and listening comprehension, which are classified as key tests for diagnosing dyslexia, affected the classification of dyslexia according to comorbidity or reading ability. However, the key results differentiated by this classification were not relevant to the reading ability test (phonological awareness, phonological memory, phonological processing ability, writing). Conclusion: In this study, diagnosis models and evaluation plans for dyslexia were presented in a language development approach in consideration of the aspect of language development from the perspective of speech-language therapy.
\end{abstract}

Keywords: Dyslexia, Diagnostic model, Comorbidity, Language development
국내 교육과정은 법령에 근거하여 마련되고 실천된다는 점에서 법제적 의미를 지닌다. 우리 나라의 경우 초·중등학교 교육은 '교 육기본법'과 ‘초·중등교육법'에 따라 운영하도록 규정되어 있다. 교 육기본법 제 2 조에는 우리나라의 교육 이념이 제시되어 있으며, 초. 중등교육법 제 23 조 제 2 항에는 초.중등학교 교육과정의 기준과 내 용에 관한 기본적인 사항을 교육부 장관이 정하도록 규정하였다. 그리고 시 · 도 교육감은 이에 근거하여 지역의 실정에 적합한 기준 과 내용을 정할 수 있도록 하고 있다. 현재 문서화된 국가 수준 교육 과정 중 가장 최근에 개정된 '2015 개정 교육과정'은 2015년 9월 23 일에 개정 고시되었다(Ministry of Education [MOE], 2015). 그리고
이외 추가로 2015년 발의된 '초· 중등 교육법 개정안(느린 학습자 지원법)'과 2017년 5월에 발의된 '기초학력보장법안'을 통해 모든 학습자의 기초학력을 보장하며, 학교 일반교육 과정에서 목표한 바 를 학습하는데 현저한 어려움이 있는 학생을 지원해주고자 하는 법안이 마련되었다(Lee \& Lee, 2019).

이전 교육과정과는 달리 '2015 개정 교육과정'의 비전은 '미래사 회가 요구하는 창의융합형 인재 양성’과 ‘학습 경험의 질 개선을 통 한 행복한 학습의 구현'으로 요약할 수 있다(Hwang, 2015). 전자가 문 - 이과 칸막이 해소 등 국가 - 사회적 요구를 반영한 비전이라면, 후자는 그 동안 추진된 교육과정 개정의 연속선상에서, 학생들이 
학습에 몰입하고 학습의 즐거움을 경험할 수 있도록 해야 한다는 한국 교육의 지속적인 발전 과제를 반영한 비전이라고 볼 수 있다. 이러한 비전 하에 특히 초등학교에서는 '2009 개정 교육과정'의 기 본 체제를 유지하면서 유치원 누리과정과의 연계성을 강화하고, 학 생의 기초학습 능력 향상 차원에서 한글교육을 강화하였다(MOE, 2015).

즉, 초등 1-2학년에서는 한글을 완전히 깨우칠 수 있도록 1, 2학 년 국어 교과서를 기준으로 한글 교육 시간이 27차시(2009 revised curriculum)에서 62차시 내외(2015 revised curriculum)로 확대됨 으로써 의무교육을 시작하는 시기인 초등학교 1-2학년에서의 기초 - 기본교육을 강화하였다. 하지만 이러한 교육현장의 변화와 함께 일반학급에서 적절한 한글교육이 주어졌음에도 불구하고 한글을 읽지 못하거나 읽기와 쓰기 능력이 또래 수준에 비하여 지체된 아 동들이 발생하였다.

이러한 아동들을 돕기 위하여 국내 전국 17 개 시 - 도교육청(서 울특별시교육청, 부산광역시교육청, 대구광역시교육청, 인천광역 시교육청, 광주광역시교육청, 대전광역시교육청, 울산광역시교육 청, 세종특별자치시교육청, 경기도교육청, 강원도교육청, 충청북도 교육청, 충청남도교육청, 전라북도교육청, 전라남도교육청, 경상북 도교육청, 경상남도교육청, 제주특별자치도교육청)은 교육청 내 교육지원청 산하에 특수교육지원센터를 두어, 읽기와 쓰기의 문제 를 보이는 학습장애 대상자들을 절차에 따라 선정하고 학습지원 을 하고 있다.

또한 추가로, 개별 시 · 도 교육청에서는 학습문제 대상자에 대해 지원을 하고 있으며, 교육청 별 그 지원 방식과 내용은 차이를 보이 고 있다. 예를 들어, 서울특별시교육청에서는 '기초학력 진단 보정 시스템(https://s-basic.sen.go.kr/pt/intro/intro.do)' 홈페이지를 마 련하여 일반교사가 학습부진 대상 학생의 기초학력 정도를 평가하 고 맞춤형 지도-관리를 지원할 수 있도록 돕고 있으며, 이와 별도로 '서울학습도움센터(http://s-iam.sen.go.kr/user/index.do)'를 설치 . 운영하여 교사 및 부모의 요구에 따라 일반학급 내 학습부진 및 난 독 학생을 대상으로 학습성취 유형 별 맞춤식 지원을 제공하고 있 다. 이외 국내 8 개 교육청(경기도교육청, 광주광역시교육청, 대전광 역시교육청, 부산광역시교육청, 울산광역시교육청, 인천광역시교 육청 충청남도교육청, 전라북도교육청)과 9 개 시 - 도 단위(경기도, 경기도 과천시, 경기도 수원시, 경기도 안양시, 경기도 오산시, 경기 도 의왕시, 인천광역시 남동구, 인천광역시 동구, 충청남도 천안시) 에서는 '난독증 학생 지원 조례'를 제정하였으며, 이에 따라 난독증 학생을 대상으로 차별적인 치료지원을 진행하고 있다(Lee \& Lee, 2019).
한글 읽기와 쓰기기술과 관련하여 국내 전국 17 개 시 · 도교육청 이 지원하는 대상자들은 난독을 포함한 학습장애 또는 난독증으 로 선별된 대상자이다. 여기에서 특히 읽기장애 또는 학습장애와 는 구별되는 난독증 진단명은 일반적으로 사용되고는 있지만, 아 직 정확한 난독증에 대한 진단 기준은 없는 실정이다. 이에 난독증 의 진단은 학습장애 진단 기준과 임상 및 연구현장에서 사용되고 있는 난독증 주요 내재요인과 배제요인을 활용하여 연구자나 임상 가의 조작적 정의 하에 정의되어 진단이 이루어지고 있는 실정이다. 그리고 국내 언어병리학의 학문적 분야에서나 임상에서 활동하는 언어재활사에게는 난독증이란 대상자를 접할 기회가 많지 않으므 로 난독증에 대한 이해 및 진단과 절차에 대해 잘 알려지지 않은 부 분이 있다.

\section{난독증의 정의, 유형 및 개념(The type and concept of dyslexia)}

난독증(dyslexia)은 글을 정확하고 유창하게 읽지 못하고 철자 를 정확하게 쓰기 힘들어 하는 것을 특징으로 하는 학습장애의 한 유형으로 읽기장애라고도 한다. 또한 정확하지만 너무 느리게 읽는 경우도 난독증으로 진단할 수 있다(Tunmer \& Greaney, 2010). 난 독증의 진단기준은 아직 명확하게 정해지지 않았지만, 평균적인 지 능에도 불구하고 읽기와 쓰기 학습 발달이 일반적이지 않다는 정 의에 있어서는 학문 및 학자 간에 일치를 보이고 있다(Lee \& Lee, 2019). 하지만 난독증 진단에 있어 이외 추가되는 내재요인과 배제 요인에 대해서는 연구자나 임상가마다 다른 적용을 하는 경우가 많아 진단기준의 일관성이 부족한 편이다(Adlof \& Hogan, 2018; $\mathrm{APA}, 2013)$. 그러므로 난독증을 진단하기 위해서는 연구자들에 의 해 일반적으로 받아들여지고 있는, 난독증의 유형과 개념, 진단모 델과 진단절차, 그리고 내재요인과 배제요인들을 구체적으로 이해 하고 있어야 한다.

난독증은 발생시기에 의해 구분하면 발달성 난독증(developmental dyslexia)과 후천성 난독증(acquired dyslexia)으로 구분된다. 발 달성 난독증은 어린 아동기부터 나타나는 것으로 지능은 정상이 지만 글자를 읽거나 쓰는데 어려움이 있는 증세를 말한다. 하지만 발달성 난독증의 정의는 학자 간에 명확하지 않으며, 대부분의 학 자들이 하나의 정의가 있을 수 없다는 데에 동의하고 있다(Adlof \& Hogan, 2018). 세계 신경학회는 정규학습 경험에도 불구하고 지적 능력에 상응하는 읽기, 쓰기, 철자법에 관한 기술들을 습득하는 데 에 어려움을 느끼는 장애를 발달성 난독증으로 분류하고 있다(National Institute of Neurological Disorders and Stroke [NINDS], 2017). 그리고 후천성 난독증은 외상성 뇌손상(Traumatic Brain 
Injury, TBI)이나 뇌졸중(Stroke)과 같은 신경학적 증상 이후에 발 생하는 것이다.

단어 재인 인지처리 경로 및 모형(dual route model [DRM], parallel-distributed processing model [PDP])에 따라서 분류하면, 후 천성 난독증은 주변성 난독증(Peripheral dyslexia)과 중심성 난독 증(Central dyslexia)으로 구분할 수 있다. 주변성 난독증은 초기 시 지각과 인지과정이 잘 이루어지지 않음으로 생기는 것으로 무시 난 독증(Neglect dyslexia), 주의성 난독증, 낱자단위읽기 난독증으로 구분된다(Nolan, Volpe, \& Burton, 1996; Vallar, Burani, \& Arduino, 2010). 중심성 난독증은 초기 시각 분석을 마친 후에 최종적으 로 단어의 음운 정보를 인출해내는 과정 중에 문제가 있거나, 철자 에서 음운으로의 재부호과정 중에 문제가 있는 것으로 표층성 난 독증(Surface dyslexia), 음운성 난독증(Phonological dyslexia), 심 층성 난독증(Deep dyslexia)으로 분류된다(Lee, Kim, \& Nam, 1998). 표층성 난독증의 경우는 철자열-음소 변환이 규칙적인 단어의 읽 기는 가능하나, 철자열-음소 변환이 불규칙적인 단어의 읽기가 불 가능한 경우이며, 음운성 난독증은 단어의 읽기는 가능하나 비단 어의 읽기는 불가능한 경우이다. 그리고 심층성 난독증은 의미는 이해하지만 읽기가 불가능하며 의미적 오류와 시각적 단어에 대한 발음오류가 나타난다(Cho, Jung, \& Nam, 2002).

이와 같은 다양한 난독증의 유형 중 특히 발달성 난독증은 그 정 의가 명확하지 않기에 진단에 대한 명확한 단일 개념이 존재하지 않는다(Lyon, Shaywitz, \& Shaywitz, 2003). 하지만 난독증을 진단 하는 데에는 몇 가지 모델이 존재한다. 이러한 모델은 난독증의 주 요 내재적 요인인 1) 읽기 학습의 심각한 결손, 2) 평균적인 지능, 3) 적절한 교수, 그리고 4) 앞의 이러한 조건에도 불구하고 예상밖의 읽기문제 등과 같은 주요 4 가지 조건을 어떻게 정의하는 지에 따라 다른 모델이 있다. 또한 이렇게 구분되어 있는 모델 중 어떠한 모델 을 적용하여 대상자를 선정하는지에 따라 난독증 진단은 차이를 보인다.

\section{난독증 진단 모델(Model of Defining dyslexia)}

난독증 초기 진단 당시에는 대상자의 기대수준과 성취수준의 차이에 의해 진단하는 '지능-성취 불일치모형(IQ-achievement discrepancy model)'이 적용되었다. 그러나 이러한 불일치모형 적용에 서 나타나는 신뢰성의 문제와 평가 시기 상의 문제 등이 논란이 되 면서 이에 대한 대안으로 중재반응모형(Response to Intervention model)이 적용되기 시작하였다. 중재반응모형은 난독 의심 대상자 에게 단계에 걸친 중재를 적용하여 이에 대한 반응을 측정하고, 중 재후의 결과를 통해 성취수준과 진전도 모두가, 또래에 비하여 현
저하게 낮은 ‘이중 불일치(dual discrepancy)’ 대상자를 난독증으로 진단하는 것이다. 하지만 이러한 중재반응모델은 교사-아동 간의 상호 역동적인 중재와 평가라는 이상적인 방안에도 불구하고 중재 의 타당성, 진단기능에 대한 의문점이 제기되고 있다(Kim et al., 2017; Kim \& Koh, 2014; Lee, 2017; Jung, 2013). 지능-성취 불일치모 형의 또 다른 대안으로 마련된 지능절단점 접근법(IQ cutoff approach) 또는 저성취모델(low achievement model)은 지능과 읽기능력 사이의 불일치를 규정하지 않고, 읽기능력이 저조한 대상자들 중 에 너무 낮은 인지능력 대상자를 배제하는 IQ 절단점을 사용하는 것이다. 즉, 난독증 진단에 좀 더 자유로운 접근법이며 임상현장에 서 가장 많이 활용되는 접근법이다(Adlof \& Hogan, 2018). 이러한 세 가지 접근법에 대해 언어병리학적 입장에서 좀 더 구체적으로 살펴보면 다음과 같다.

\section{불일치모델(The IQ achievement discrepancy model)}

IQ 점수와 표준 참조 검사(norm-referenced measure)를 이용한 읽기능력의 정확도와 속도 평가결과 점수가 차이를 보이는 대상자 들을 난독증으로 진단하는 것은 교육과 연구분야에서 주로 이용 된 접근법이다(Pennington, Gilger, Olson, \& DeFries, 1992; Shaywitz, Shaywitz, Fletcher, \& Escobar, 1990). 여기에서 IQ 점수는 아 동의 기대수준을 의미하며, 읽기점수는 성취수준을 의미하는 것으 로 지능-성취 불일치모형(The IQ achievement discrepancy model) 은 아동의 기대수준과 실제 성취수준의 차이를 주요 조건으로 하 여 학년수준 편차 공식, 기대학력 공식, 표준점수 비교 공식, 회귀 공식 등을 사용하여 불일치 정도를 계산하는 방식으로 난독증을 판별하는 것이다(Kim \& Koh, 2014). 이러한 지능-성취 불일치모형 은 전통적으로 오랜 기간 동안 사용되었으며 일반적으로 불일치모 델(discrepancy model)로 불리고 있다.

불일치모델을 적용한 난독증 진단에서는 다음과 같은 4 가지의 주요 문제가 언급되었다. 1) IQ 점수가 대상자의 잠재력을 나타내는 지표라고 가정했고, IQ 점수보다 현저히 낮은 단어 읽기 점수는 대 상자가 자신의 잠재력을 최대한 발휘하지 못하고 있다는 증거로 보 았다. 또한 2) 이러한 접근법 하에서 적용된 IQ 점수는 언어성과 비 언어성 IQ 점수를 모두 합친 전체 IQ 점수를 이용하는 경우가 많았 다. 따라서 이 접근법에서는 다양한 언어문제를 동반한 대상자가 높은 IQ 점수를 얻을 가능성이 낮기 때문에 정상적인 언어능력을 가진 아동보다 난독증 진단을 받을 수 있는 가능성은 적었다. 그리 고3) 이처럼 단어 읽기 점수와 IQ 점수가 모두 낮게 나타난 대상자 들은 난독증이 아닌 일반적인 읽기장애(garden variety)로 분류하 여, 난독증을 대상으로 진행하는 읽기중재에 있어 그 중재 효과가 
거의 없을 것이라고 간주하였다(Gough \& Tunmer, 1986; Stanovich, 1991). 4) 읽기는 공식적인 교육을 필요로 하기 때문에 불일치 모델을 적용하여 난독증을 판별하는 것은 공교육이 시작되는 시점 에서 가능하다는 시간적인 제약이 있다. 이러한 불일치모형을 이용 한 난독증 진단의 문제를 해결하기 위하여 등장한 모델이 중재반 응모델과 지능절단점 접근법이다.

\section{중재반응모델(Response to Intervention, RTI)}

읽기문제가 있는 초등학교 1학년 대상자들을 선별하여 Vellutino 등(1996)은 증거기반의 집중적인 읽기관련 중재를 6개월간 적 용하였다. 그 결과 대상자들 대부분은 읽기능력이 향상되었으며 나머지 소수 집단 아동만이 여전히 음운기술 능력이 부족하였고, 읽기중재의 효과도 저조하였다. 이러한 연구결과에 대해 Vellutino 등(1996)은 읽기문제로 의뢰된 아동 중에 읽기훈련과 읽기경험 부 족으로 저조한 읽기능력을 보이는 아동은 학습장애 대상자에서 배제하여야 한다고 보았다. 즉, 집중적인 중재가 적용된 후에도 여 전히 읽기의 문제가 두드러지는 대상자만을 학습장애 또는 읽기장 애로 진단해야 한다고 보았다(Torgesen, 2000; Wolf, 1999). 그리고 이러한 RTI모델은 2004년 미국연방특별교육법(Individuals with Disabilities Education Improvement Act [IDEA], 2004; PL 108-446) 에 적용되어 공립학교에서 학습장애를 진단하는 모델로, 그리고 국내에서는 교육부가 '학습장애학생 선정 조건 및 절차(MOE, 2014)' 에 RTI를 제시하여 학습장애를 진하고 그 진단 결과여부에 따라, 특수교육지원센터의 특수교육 지원을 받을 수 있도록 하였다(Special Education support Center, Seoul Metropolitan of Education. http://www.sen.go.kr/sedu/sedu/index.do).

하지만 이러한 RTI모델은 난독증 진단을 위해 사용하기에는 다 음의 3가지 주요 문제를 가진다. 1) RTI모델은 진단보다는 특수교 육지원 대상자를 선별하기 위한 방안이므로 난독증 진단 적용을 중요하게 다루고 있지는 않다. 2) RTI에 적용되는 과학적으로 검증 된 중재에 대한 기준이 모호하고 중재효과를 측정하는 방법에 있 어서도 통일된 안을 마련하기 어렵다. 그리고 3) RTI 모델 적용 후에 도 읽기 진전이 저조한 대상자들은 전반적인 언어능력에 있어 문제 를 보이는 난독 대상자들이었다는 한계가 있다. 즉, 지능 및 자조학 습능력 등으로 인해 중재에 진전을 보인 대상자들 중에 난독증 진 단 대상자가 포함될 가능성이 있다는 한계가 있다(Vadasy, Sanders, \& Abbott, 2008; Whiteley, Smith, \& Connors, 2007).

\section{지능절단점 접근법(IQ cutoff approach)}

지능절단점 접근법은 저성취모델(low achievement model)로 불
려지는 것으로 불일치모델의 대안으로 마련되었다. 이는 난독증 진 단에 다소 더 자유로운 접근을 위해 IQ점수와 읽기 능력 사이의 불 일치를 규정하지 않고, 낮은 인지 능력을 배제하는 접근법으로 현재 임상에서는 가장 많이 적용되고 있다(Vellutino, Scanlon, \& Reid Lyon, 2000; Wimmer, Mayringer, \& Landerl, 2000). 이러한 지능절 단점 접근법은 읽기능력은 저조하지만 평균적인 지능을 가진 대상 자들을 난독으로 규정하고 있다는 점은 불일치모델과 유사하다. 하지만 IQ 점수 적용에 있어 언어성과 비언어성을 구분하여 측정 하고 주로 비언어성 IQ 점수만을 엄격하지 않은 적용범위(평균점 수 2 표준편차 이내)에서 절단점으로 사용한다는 차이를 보이고 있 다. 엄격하지 않은 $\mathrm{IQ}$ 점수 절단점을 이용한다는 것은 인지적인 결 함 대상자만을 난독증에서 배제하기 위한 것으로, 평균지능 점수 의 2 표준편차(Standard deviation, SD) 내에 속하는 대상자를 난 독증으로 규정하는 것이 일반적이다(Alt et al., 2017).

지능절단점 접근법은 이전의 진단모델의 대안으로 적용된 접근 법이므로 불일치모델과 비교하여서는 대상자에게 높은 언어성 IQ 점수를 요구하지 않아 언어적 문제와 지능의 문제를 분리하였다는 장점을 가진다. 그리고 RTI모델과 비교하여서는 난독증을 진단하 기 위한 논리적 접근에 있어 중재와 진단을 분리하였다는 간편성과 음운능력 이외의 언어능력의 문제를 함께 보이는 아동도 난독증 치료지원 대상자로 선정될 기회를 확대하였다는 장점을 지닌다. 하 지만 지능절단점 접근법을 적용한 난독증 진단에 있어 1) 평균적인 지능이란 어느 정도여야 하는지, 2) 적절한 학습이 이루어졌음에도 불구하고 성취수준이 낮은 것인지 등에 대한 정의가 명확하지 않 다는 문제점을 가진다.

난독증 진단모형은 이처럼 꾸준히 변화되어 왔으며, 제시된 세 가지 진단 모델들은 각각의 장점과 단점이 공존하고 있는 상황이 다. 따라서, 임상과 연구현장에서는 위의 세 가지 난독증 진단모델 을 구체화하여, 난독증 진단에 포함되어야 하는 내재요인과 배제요 인을 모두 포함한 구체적인 난독증 대상자 선정조건과 절차가 요구 된다. 하지만 현재 난독증의 정의와 진단과 절차에 대한 학자들 간 의 합의는 존재하지 않고 있다. 이에 임상 및 연구에서 주로 활용되 는 Diagnostic and Statistical manual of Mental disorders-5 [DSM-5]; $\mathrm{APA}, 2013)$ 를 통해 난독증의 선별과 절차, 배제요인의 윤곽을 살펴 보면 다음과같다.

\section{난독증 선별절차, 배제요인(Identifying procedures, and exclusion factors of dyslexia)}

DSM-5 (APA, 2013)에서는 난독증만을 구분하여 구체적으로 다루고 있지는 않고 학습장애와 연관하여, 그 진단 기준과 절차, 배 
제요인을 제시하고 있다. 이러한 기준은 임상가가 대상자의 진단명 을 정하고 치료를 진행하는데 활용되거나, 연구자가 연구대상자를 선정하는 기준이 되고 있다. 즉, DSM-5 (APA, 2013)의 자료 내용을 이해하는 것은 치료와 연구에서 난독 대상자 또는 학습장애 대상 자가 어떠한 조건과 절차에 따라 진단되고, 또한 대상자로 선정되 는 지를 살펴볼 수 있는 자료이다. 이에 DSM-5 (APA, 2013)의 기준 안을 자세히 살펴보면 다음과 같다.

\section{DSM-5 (APA, 2013)}

미국정신의학회(American Psychiatric Association, APA)에서 출간하는 정신질환 진단 및 통계 편람(DSM-5; APA, 2013)에는 각 종 정신질환의 종류를 구분 짓고 있으며, 또한 증상 진단의 기준을 제시하여, 전 세계의 임상가들과 연구자들이 참고할 수 있도록 한 통계편람이다. 이러한 DSM-5 (APA, 2013)에서는 난독증을 신경학 적 원인에 의해 발생하는 것으로 보았으며, 모든 학습장애를 포괄 하는 분류인 특정학습장애(Specific Learning Disorders, SLD)로 간주하였다. 구체적으로 DSM-5에서 난독증은 신경생리학적으로 지능과 시력, 청력 등이 모두 정상임에도 불구하고 언어와 관계되 는 신경학적 정보처리 과정의 문제로 인해 글을 원활하게 읽고 이 해하는데 어려움을 겪는 증상'으로 정의하고 있으며, 난독증의 진 단시기, 기준, 배제요인에 대해 명확한 제시를 하였다(Figure 1).

첫째, 난독증의 진단시기에 있어, DSM-5 (APA, 2013)에서는 특 정학습장애의 진단시기가 초기 학령기에만 국한되지 않는다는 것 을 명확하게 밝히고, 후기 학령기에도 학습장애가 진단될 수도 있 다는 점을 강조하였다. 이는 학업적 어려움은 초기 학령기에 시작
되나 개인의 제한된 학습능력을 넘어선 학업기술이 요구되기 전까 지 명백하게 나타나지 않을 수도 있다는 가능성을 포함한 것이다. 둘째, 진단기준에 있어, IQ-성취도 불일치 기준이 삭제되는 것이 제 안되면서 이를 대신할 수 있는 학습장애 선별기준은 무엇이 되어 야 하는지에 대한 고민 속에서 RTI모형, 학업적 어려움의 지속성, 심리과정적 손상, 정상 $\mathrm{IQ}$ 수준을 가진 학생의 지속적인 저성취의 기준을 제시하였다. 각 대안적 기준들에 대한 찬반의 논란 속에서 표준화된 검사도구를 통한 수량화 된 저성취도 기준이 가장 적절 할 것이라는 것을 제안하였고, 이때 저성취도는 동연령의 평균에서 적어도 표준편차 1.5 이하를 나타내며, 매우 명백한 임상학적인 증 거가 있을 때는 표준편차 1.0-1.5도 적용될 수 있다고 제안하였다.

그리고 셋째, SLD 선정 시 배제해야 할 요인에 대한 기준을 명확 히 제시하였는데, 1) 학업적 어려움은 정신지체, 교정되지 않은 시 력과 청력의 문제, 2) 다른 정신 또는 신경학적 장애, 3) 심리사회적 역경, 4) 언어문제, 또는 5) 부적절한 교육으로 인해 기인될 수 없다 는 것을 밝혔다. 구체적으로, 학업적인 어려움은 경제적 또는 환경 적인 불이익, 만성적인 결석, 지역사회 내에서 전형적으로 제공되는 교육의 부족과 같은 일반적인 외부 요인에 의해서 기인할 수 없다고 밝혔다. 또한 학업적 어려움이 자주 동반되는 소아과 뇌졸중과 같 은 신경학적인장애, 운동기능적인장애 또는 시각 또는 청각장애로 기인할 수 없다는 것을 추가적으로 제시하였다(Na \& Seo, 2013).

\section{난독증 진단에 대한 문제(Problems in diagnosis of dyslexia)}

앞서 난독증의 유형과 개념, 진단모델, 선별절차와 배제요인에 대 해 임상과 연구현장에서 활용되는 것들을 살펴보았다. 하지만, 이

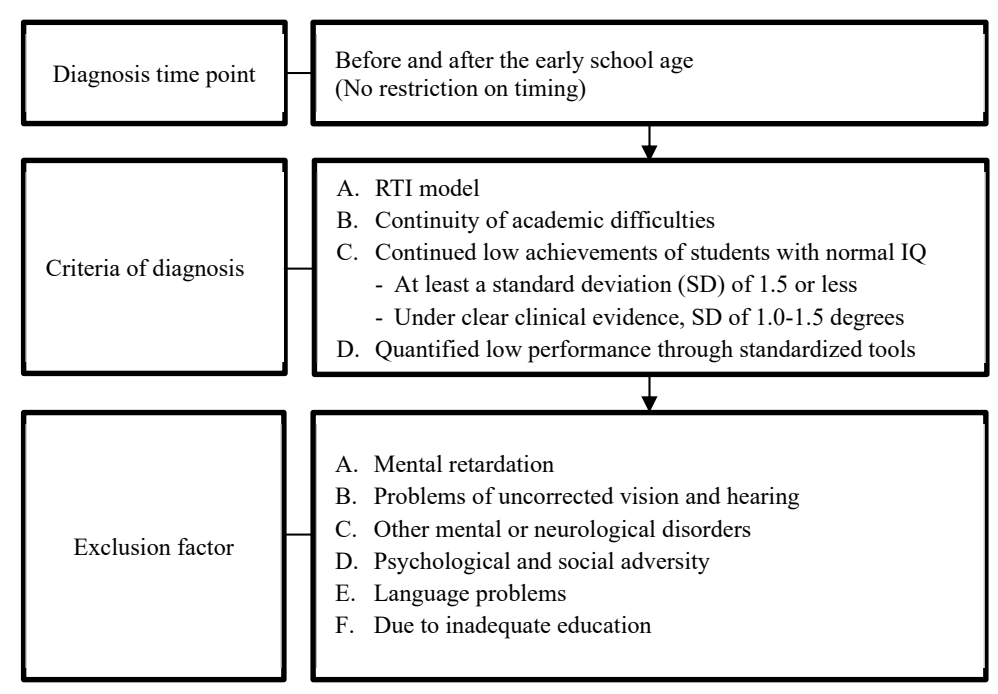

Figure 1. Identifying procedures of dyslexia in DSM-5.

$\mathrm{IO}=$ intelligence quotient; $\mathrm{RT} \mid=$ response to intervention; $\mathrm{SD}=$ standard deviation . 
러한 난독 진단모델과 선별절차는 현재까지 다양한 난독 연구에 있 어 일치하지 않고 있다. 일반적으로 난독에 대한 정의에 있어 포함 되어야 하는 특징으로는 표준화된 읽기와 쓰기 평가에서 단어 읽 기, 해독 및 철자법에 대한 낮은 정확성과 읽기 유창성 문제가 지적 발달 측면을 고려하였을 때 모순되거나 일반적이지 않음을 포함하 여야 한다는 기준에는 거의 모든 연구에 있어 동의하였다(APA, 2013; NINDS, 2017). 그리고 난독증 배제 요인으로써 포함된 시각 이나 청력의 문제, 머리부상, 신경발달 증후군, 잘못된 학습으로 인 해 아동에게 나타나는 읽기와 쓰기 어려움은 난독증으로 정의될 수 없었다(APA, 2013). 하지만 실질적으로는 연구와 임상현장에서, 이러한 내재와 배제요인은 다양하게 적용되어 난독증을 진단하는 데 활용되고 있으므로 난독증에 대한 추정 유병률(prevalence rates) 은 인구 대비 최저 $3 \%$ 에서 최고 $20 \%$ 까지 그 변화가 크다(Adlof \& Hogan, 2018; Rutter et al., 2004; Shaywitz, 1996; Spencer et al., 2014).

난독증에 대한 진단 기준에 있어 내재와 배제요인에 있어 연구 자들마다 다른 조작적 정의를 제시하는 데는 몇 가지의 요인이 존 재한다. 첫째, 난독증 진단모델과 DSM-5 (APA, 2013)의 난독증 진 단기준에서는 난독증 진단 시기가 정해지지 않았다. 둘째, 난독증 진단내용에 있어 읽기문제를 진단하는 관련 변인 부분에 대한 논 의가 부족했다. 이전 연구에 의하면 난독증은 읽기 정확성이 떨어 지거나 읽기 속도가 느린 경우를 포함한다고 하였다. 그러므로 읽 기의 정확성과 읽기 유창성 점수가 일반 대상자들과 비교하였을 때 저조한 경우이다. 하지만 난독증의 진단시기가 정해져 있지 않 은 조건에서 1) 학령전기에 읽기를 아직 학습하지 못하였을 때는 어 떻게 난독증 대상자를 구분할 것인가? 그리고 2) 개인의 학습 전략 과 노력으로 읽기와 읽기 유창성 부분에 있어서는 어느 정도 평균 수준에 도달한 난독증 대상자는 어떻게 구분하여 진단할 것인가? 3) 난독증과 언어문제를 모두 보이는 아동은 어떻게 구분할 것인 가? 즉, 난독증을 연령과 관계없이 정확하게 진단하기 위해서는 평 가 내용에 있어 읽기 이외에 언어능력에 대한 평가가 종합적으로 이루어져야 한다. 또한 읽기와 쓰기문제가 동반될 수 있는 관련 변 인들의 문제에 대해서도 관찰과 평가가 필요하다. 이에 현재까지 진 행된 난독증 연구에서 난독증과 관련이 있는 것으로 나타난 언어 및 관련 변인들을 살펴보면 다음과 같다.

\section{난독증과 관련된 변인(Variables associated with dyslexia)} 시청각 지각(Visual and auditory perception)

우선 난독증을 처음 접하게 된다면 먼저 알아보고 싶은 부분은 '시각과 청각능력이 일반인과 다른가?'일 것이다. 난독증의 초기 연 구에서는 이러한 주제가 많이 다루어 졌는데(Kim \& Cho, 2010;
Kim, Lee, \& Jeong, 2011; Lee, Park, Lee, Whang, \& Ryu, 2011), 현 재는 시각과 청각의 문제로 읽기에 문제가 발생하는 대상자는 난 독증의 배제요인으로 분리된 상태이다(APA, 2013).

\section{시청각 정보처리능력(Visual and auditory information processing abilities)}

지각적 문제가 아니라면 다음으로 알아보아야 할 주제는 '시 · 청 각적 정보처리능력은 어떠한가?'에 대한 부분일 것이다. 이러한 부 분에 대해서는 아직까지도 계속 연구가 진행되고 있으며, 연구결과 는 차이가 있기도 하고 없기도 하였다(Christmann, Lachmann, \& Steinbrink, 2015; Geiser, Kjelgaard, Christodoulou, Cyr, \& Gabrieli, 2014). 그러므로 전반적인 청각 또는 시각적 정보처리능력의 결 함보다는, 미세한 정보처리 부분에 있어 난독증은 일반인과 차이 가 있을 수도 있고, 아니면 난독증 연구대상자 표집 집단에 따라서 차이가 있었을 가능성도 있다.

\section{음운처리(Phonological processing)}

시·청각 정보처리능력 결함이 주요문제가 아니라면 음운처리의 문제가 난독과 연관되어 있는 것은 아닐까? 이러한 연구주제로 진 행된 연구결과는 음운처리와 음운산출의 문제가 난독과 관련이 있는 것을 확인하였으며(Cabbage, Farquharson, Iuzzini-Seigel, Zuk, \& Hogan, 2018; Daikhin, Raviv, \& Ahissar, 2017; De Luca, Marinelli, Spinelli, \& Zoccolotti, 2017; Griffiths \& Snowling, 2001; Hanly \& Vandenberg, 2010; Hakvoort et al., 2016; Wijnen, Kappers, Vlutters, \& Winke, 2012), 일부 난독증 아동에게서 나타나는 설단현상(Tip of the tongue, TOT)과 단어인출 결함(word retrieval deficits) 결과를 그 증거로 제시하였다(Faust, Dimitrovsky, \& Shacht, 2003; Hanly \& Vandenberg, 2010). 그리고 성조에 대한 이해가 언어 이해에 크게 작용하는 중국어 사용 난독증 대상자들은 억양(tone) 과 운율(rhyme)을 인식하는 능력이 일반 대상자들에 비하여 유의 미하게 저조하였다는 연구결과도 있다(Li \& Ho, 2011). 또한 난독 청소년들의 어휘에 대한 기억 및 처리능력을 측정한 결과, 일반 대 상자들은 유사한 음운정보 문자 단어들을 더 잘 기억하고 있는 반 면, 난독증 대상자들은 의미적으로 유사한 단어들을 일반 대상자 보다 더 잘 기억하고 있었다(Obidzinski \& Nieznanski, 2017). 이러 한 연구결과에 대해, 난독증 대상자들은 음운정보처리가 일반 아 동보다 지체되어 있는 것이 아니라, 일반 대상자와는 다른 처리 능 력이 발달되어 있다고 해석하였다. 
작업기억 능력(Working memory capability)

난독증 대상자들의 어휘산출 및 정보처리의 문제를 작업기억 능 력과 관련하여 살펴본 연구도 진행되었다. 연구결과 난독증을 보이 는 청소년들의 주의와 억제 작업기억 능력은 일반 대상자보다 더 낮게 나타났음을 보고하였다(Gray et al., 2019; Hachmann et al., 2014; Kapoula et al., 2010; Moll, Hulme, Nag, \& Snowling, 2015). 그리고 Pacheco 등(2014)은 2-5학년 초등학교 난독증 아동 35명을 대상으로 지능, 단기기억, 어휘능력, 음운인식, 빠른 이름대기 등을 측정하여 대상자들의 인지 처리능력을 프로파일 분석하였다. 그 결과 대상자들 간에 측정변수 결과는 음운인식 능력의 결함이라 는 공통된 결과 이외에 인지적 측정변수에 대한 결과는 다양하였 다. 이에 연구자는 난독증이란 언어, 인지, 정보처리, 지능 등이 서 로 다르게 관련된 증상으로 진단시에 다양한 영역에 대한 평가가 요구되고 이러한 결과에 따라 개별 치료가 요구된다고 보고하였다.

\section{통계적 학습(Statistical learning)}

이후 발달성 난독증 아동의 읽기문제는 통계적 학습(statistical learning) 능력에 문제가 있기 때문일 수 있다고 보는 연구가 진행되 었다. 통계적 학습이란 훈련 데이터 집합을 통해 배우는 것을 의미 하는 것으로, 난독 아동의 읽기문제는 문자의 배열과 결합에 대한 절차적 방법에 대해 학습하는 것이 느리거나 결함을 보인다는 것을 연구결과를 통해 제시하였다(Arciuli, 2018; Bulgarelli, Lebkuecher, \& Weis, 2018; Gabay, Thiessen, \& Holt, 2015; Treiman, 2018).

\section{유전적 문제(Genetic linkage)}

그리고 난독증 유전자의 문제가 제기되었다. 이는 난독증을 보 이는 아동의 부모를 대상으로 연구가 진행되었으며, 종단연구 및 유전자 분석연구를 통해 어느 정도 이러한 부분은 난독증과 연관 되어 있음이 입증되었다(Buonincontri et al., 2011; Holttum, 2016; Pacheco et al., 2014; Scerri \& Schultekorne, 2010; Taylor, 2004; van Viersen, de Bree, Kalee, Kroesbergen, \& de Jong, 2017).

\section{철자법의 투명성과 외국어학습(Orthographic transparency effects and foreign language learning)}

이외에 난독증은 문자언어와 깊은 관련이 있으므로 특정 언어가 난독증과 관련이 있는 것은 아닌지? 그리고 난독증이 있는 대상자 들도 외국어 학습이 가능한지에 대한 연구가 진행되었다. 연구결과 읽기 유창성에 있어 철자의 투명성이 영향을 미치는 것으로 확인되 었는데, 문자 별로 음소와 자소의 결합이 투명한지 불투명한지에 따라 각 나라 별 난독증 발생 비율이 다르게 나타난 것을 확인할
수 있었다(Bogdanowicz \& Bogdanowicz, 2016; Eellis \& Hooper, 2001; Ho \& Fong, 2005; Law \& Yeung, 2010; Łockiewicz \& Jaskulska, 2019; van Viersen, de Bree, Kalee, et al., 2017). 즉, 문자에 따라 철자가 읽기에 있어 좀 더 명확하게 결합된 투명한 문자(한국어, 독 일어, 이탈리아어, 스페인어, 터키어)보다는 불투명한 문자(영어, 프 랑스어, 네델란드어, 덴마크어, 중국어)를 사용하는 나라에서 난독 증의 비율이 더 높게 나타났다. 그리고 난독증 대상자가 외국어를 학습하는 것은 지능과 인지능력에 따라 다르지만 대체로 일반 대 상자들에 비하여 외국어 읽기와 쓰기에 어려움을 보였다(van Viersen, de Bree, Kalee et al., 2017).

\section{난독증과 $A D H D$}

난독증과 또는 읽기장애와 주의력결핍 과잉행동장애(Attention Deficit Hyperactivity Disorder, ADHD)가 함께 나타나는 아동들 을 통해 난독증과 $\mathrm{ADHD}$ 의 공존가능성을 살펴본 연구들이 진행 되었다. 연구결과 읽기 발달 초기인 7-9세 아동에게 흔히 보일 수 있 는 $\mathrm{ADHD}$ 성향이 난독 아동의 읽기문제 발현시기와 맞물려 공존 하는 것으로 보일 수도 있으며(McGee, Brodeur, Symons, Andrade, \& Fahie, 2004), 읽기와 관련된 인지능력이 주의(Attention) 작동과 관련이 있어 난독증과 $\mathrm{ADHD}$ 가 함께 나타나는 경우가 발생하는 것으로 보았다(Redmond, Ash, \& Hogan, 2015; Shaywitz \& Shaywitz, 2008).

\section{난독증과 DLD}

다음으로, 난독증과 발달언어장애(Developmental language Disorders, DLD)는 구분되는 증상인지에 대한 연구가 진행되었다. $\mathrm{DLD}$ 는 신경생리적 또는 인지적 결함은 없으며, 적절한 언어환경이 주어졌는데도 특정 언어능력에 결함을 보이는 대상자이다(Bishop, Snowling, Thompson, Greenhalgh, \& CATALISE-2 consortium, 2017; Leonard, 2014). 이러한 언어발달 측면에서 보면 난독증과 $\mathrm{DLD}$ 는 언어적 발달 측면에서만 문제를 보인다는 유사한 특성을 보이고 있다. 이에 몇몇 연구는 난독증과 DLD가 구분될 수 있는지 에 대한 연구가 진행되었다. 연구결과 난독증 대상자의 $55 \%$ 는 DLD 로 구분될 수 있었으며 DLD 대상자들의 51\%는 난독증을 보이고 있었다(McArthur, Hogben, Edwards, Heath, \& Mengler, 2000). 또 다른 연구에서는 난독증 집단은 음운처리(phonological processing) 능력 결함이 정상과 DLD 집단보다 더 두드러지게 나타났 지만 난독증과 DLD 특성을 모두 보이는 집단과는 유사하였다는 연구결과를 제시하였다(Adlof \& Hogan, 2018; Catts, Fey, Tomblin, \& Zhang, 2002; Catts, Adlof, Hogan, \& Weismer. 2005; De Groot, 
Van den Bos, Van der Meulen, \& Minnaert, 2015; Hendricks, Adlof, Alonzo, Fox, \& Hogan, 2019; Shareef, Östberg, \& Hedenius, 2019). 즉, 난독증과 $\mathrm{DLD}$ 는 음운처리 능력 측정으로 어느 정도 구 분 가능하지만, 공존장애의 가능성이 있다고 정리할 수 있다(Alt et al., 2017; Alt, Gray, Hogan, Schlesinger, \& Cowan, 2019).

\section{난독증 아동의 언어발달(Language development of dyslexia children)}

난독증 대상자들의 언어발달에 대한 연구도 몇몇 진행되었는데 Sumner, Connelly와 Barnett (2013)은 9살 난독증 아동 31명과 또 래 아동과의 쓰기 시간을 비교한 결과 난독증 대상자들이 손 글씨 쓰기에는 일반 대상자들에 비하여 유의미하게 저조한 속도를 보였 다. 하지만 태블릿(digital tablet writing)을 이용하여 글쓰기를 하 였을 때는 두 집단 간에 차이가 없었다. 이러한 결과에 대해 연구자 는 철자쓰기는 인지적인 처리요소가 영향을 미치는 부분으로, 난 독증 대상자의 저조한 철자 능력이 쓰기에 영향을 미친 것으로 해 석하였다. 그리고 보스니아 난독증 8 세 아동 45 명의 언어형태 지식 을 측정한 결과 난독증 아동들은 일반 또래와 비교하여 거의 모든 단어 및 구문형태 지식 능력이 저조한 것을 확인하였다. 그러므로 난독증 아동에 대한 언어발달을 지속적으로 점검해야 한다고 논 의하였다(Duranovic, Tinjak, \& Turbic-Hadzagic, 2014).

초등학교 2학년 난독증 아동을 대상으로 어휘학습 능력을 살펴 본 연구도 있었다. 이 연구에서는 새롭게 만든 인공단어의 이름과 형태를 기억하고 산출하는 과제를 통해 단어학습 능력을 살펴본 결과 난독증 대상자들은 새로운 단어의 이름을 기억하여 산출하 는 능력은 일반 아동에 비하여 유의미하게 저조하였다. 하지만 새 로운 단어와 관련된 조작물의 시 - 공간적 정보를 기억하고 산출하 는 학습능력은 일반 아동에 비하여 더 유의미하게 잘하는 과제도 있었고 아닌 과제도 있었다. 즉, 시 · 공간과제는 음운처리 능력이 요 구되는 정도에 따라서 영향을 받았다(Alt et al., 2017).

van Viersen, de Bree와 Verdam 등(2017)은 난독증 가족력이 있 는 초등학교 2학년 51명 네덜란드 대상자들의 수용 및 표현어휘 능 력을 측정하여 가족력이 없는 난독증 대상자와 일반 아동과 비교 하였다. 연구결과 가족력이 있는 난독증 대상자들은 일반 아동에 비하여 15 개월 이상 지체된 것을 확인할 수 있었다. 이러한 결과를 바탕으로 연구자는 아동시기에 어휘능력의 부족은 난독증의 추가 증상으로 봐야 한다고 논의하였다. 그리고 난독증 가족력이 있는 아동은 학령기 이전에 말소리장애(Speech sound disorder: SSD)의 특징을 보일 수 있으므로 이들 대상자들은 발화능력에 대한 점검 과 음운인식, 읽기능력에 대한 종단적인 점검이 요구된다고 보고한
연구도 있다(Cabbage et al., 2018).

이와 같은 난독증과 관련된 현재까지의 연구들을 살펴본 결과, 난독증 진단 시기와 대상자의 동반문제를 고려하여, 난독증에 대 해 정확한 진단을 진행하기 위해서는 진단모델 평가에 다음과 같은 2 가지가 추가되어야함을 알 수 있었다. 첫째, 난독증의 주요 동반장 애로 알려져 있는 청각적 정보처리 문제, 작업기억 용량문제, 유전 적 요인, $\mathrm{ADHD}, \mathrm{DLD}$, 그리고 $\mathrm{SSD}$ 동반 여부도 조사 또는 평가가 진행되어야 한다. 둘째, 난독증 진단모델에서 읽기 성취도 기준으로 작용하는 읽기와 읽기 유창성검사 이외에, 음운인식, 음운처리능력 (빠른 이름대기), 음운기억, 그리고 언어능력(어휘능력, 듣기/읽기이 해, 쓰기)과 같은 읽기관련 변인들이 추가평가 되어야한다.

그리고 이러한 추가 평가에 대한 타당성을 입증하기 위해서는 우 선, 진단모델을 이용한 난독증 진단결과 특성을 살펴보고, 둘째, 진 단모델 진단결과와 대상자의 동반장애 또는 증상과의 연관성을 분 석하고 연관성 결과에 따라 난독증 대상자들이 구분되는지를 알 아보아야 한다. 그리고 마지막으로, 진단모델과 난독증 대상자의 동반장애 또는 증상과의 연관성 집단에 따라 주요 핵심 읽기평가 (해독, 읽기 유창성, 이해) 결과와 추가 읽기관련 변인 평가 결과의 프로파일을 분석하여 구분된 집단에 따라 프로파일의 차이가 있 는지를 살펴 보아야한다.

이러한 연구목적 하에 구체적으로 이번 연구에서는, 1) 기존 3 가 지 진단모델(불일치모델, RTI, 지능절단점 접근법)에 의해서만 난 독증을 진단하고, 2) 진단모델 난독증 진단결과와 대상자의 동반장 애 및 동반증상과의 연관성을 분석하고, 3) 연관성 분석 결과를 통 해 구분되는 난독증 집단에 따라 지능과 읽기 능력을 포함한 음운 $\&$ 인지처리, 음운기억, 언어능력(어휘능력, 듣기/읽기이해, 쓰기)을 프로파일 분석, 비교하여 살펴보았다.

\section{연구문제}

연구문제 1. 진단모델별 난독증 진단결과와 난독증 대상자의 동 반장애

1-1. 진단모델(불일치모델, RTI, 지능절단점 접근법) 적용별 난 독증 진단이 차이를 보이는가?

1-2. 난독증 대상자의 동반장애 또는 동반증상에는 어떠한 것이 있나?

연구문제 2. 진단모델에 따른 난독증 진단결과와 난독증 대상자 의 동반장애는 연관성이 있는가?

연구문제 3. 연구문제 2의 평가 결과에 따라 나뉘어진 집단별 읽 기관련 변인(음운 \& 인지처리, 음운기억, 언어능력[어휘능력, 듣기/ 읽기이해, 쓰기]) 측정결과 프로파일은 차이가 있나? 


\section{연구방법}

\section{연구대상}

서울시교육청 서울학습도움센터는 일반 공립학교에 재학중인 학습부진 초·중·고등학생에 대해 학교와 학부모, 전문가의 유기 적 연계를 통한 개별 맞춤 학습지원을 제공하고 있다. 즉, 학교 기초 학력(3Rs: reading, writing, arithmetic) 진단 평가에서 기초학력 부 진으로 평가된 개별 학생의 학습부진 요인을 참고하여, 1) 기초학 력 부진 대상자에 대한 심층 학습상담(한글 읽기 및 쓰기, 수감각 익히기, 기초 연산 및 구구단 습득)을 진행한다. 그리고 2) 심층 학 습상담 결과 난독 또는 학습경계선의 문제가 있는 것으로 평가된 대상자에 한해서는 지능 상담을 진행한 후, 3) 대상자 특성에 맞게 전문 치료기관에 대상자를 연계하고 있다. 이러한 유기적 연계 지 원 절차 과정에서 교사컨설팅, 교사 및 학부모 단체 연수, 학부모 상 담과 같은 교사/학부모 지원 프로그램 또한 운영하고 있다.

이중 난독증 전문 지원 사업은 2019년 4월에 서울학습도움센터 에서 서울시내 개별 초등학교에 공고안을 제시하고 대상자를 모집 하여, 9월부터 대상자 모니터링이 시작되었다. 즉, 2019년 9월부터 서울시내 모든 공립 초등학교에 지원자 모집 공문을 보내고, 담임 교사 또는 학부모 상담과 지원자의 학습상담 절차를 거쳐 난독증 대상자를 선별하였다. 그리고 난독증으로 의심되는 대상자 9 명에 대한 난독 치료가 2019년 11월 대학 내 언어병리학과에 의뢰되어 언어재활사에게 연계되었다.

언어재활사에게 연계된 난독 치료 대상자는 총 9명이었으며, 초 등학교 1학년이 4명, 2학년 2명, 4학년이 3명이었다. 학년별 대상자 의 평균 연령은 1 학년은 7세 2 개월, 2 학년은 8 세 7 개월, 그리고 4 학 년은 10 세 3 개월이었다. 대상자의 성별은 남아가 6 명 $(66.67 \%)$ 여아 가 3 명(33.33\%)으로 남아가 여아보다 2배 더 많았다. 난독증 의심

Table 1. Participants' information $(\mathrm{N}=9)$

\begin{tabular}{lcccccc}
\hline N & Participants & Gender & Age & Grade & SDOE & Com \\
\hline 1 & Si & M & $6 ; 11$ & 1st & Western & DLD \\
2 & Do & M & $7 ; 01$ & 1st & Western & \\
3 & Tae & M & $7 ; 01$ & 1st & Gangbuk & ADHD \\
4 & Seung & M & $7 ; 09$ & 1 st & Gangseo & ADHD \\
5 & Jung & M & $8 ; 05$ & 2nd & Gangnam & \\
6 & Yu & F & $8 ; 09$ & 2nd & Seocho & \\
7 & Hyun & F & $10 ; 00$ & 4th & Gangnam & SSD \\
8 & Da & M & $10 ; 04$ & 4th & Northern & \\
9 & Rae & F & $10 ; 07$ & 4th & Central & \\
\hline
\end{tabular}

$\mathrm{ADHD}=$ attention deficit hyperactivity disorders; $\mathrm{Com}=$ comorbidity; $\mathrm{DLD}=$ developmental language disorders; $\mathrm{SDOE}=\mathrm{School}$ district for office of education; $\mathrm{SSD}=$ speech sound disorders.
증상 대상자를 소속된 초등학교 지역교육청(11개: 동부, 서부, 남부, 북부, 중부, 강동송파, 강서양천, 강남서초, 동작관악, 성동광진, 성 북강북) 별 권역으로 구분하였을 때 대상자는 서울 서부교육청이 2 명, 북부교육청 1 명, 중부교육청 1 명, 강서교육청 1 명, 강북교육청 1 명, 강남교육청 3 명으로 구분되었다(Tables 1,2 ).

난독증 의심 대상으로 연계된 9명 초등학생들에 대한 보호자 및 담임교사 초기 전화상담을 실시한 결과 읽기와 쓰기 문제 이외에 다른 문제를 동반하는 아동은 4 명으로 확인되었다. $\mathrm{Si}$ 아동은 유아 기부터 또래보다 말이 느려서 유치원 때부터 언어치료와 인지치료 를 병행하고 있었으며, Seung과 Tae 아동은 $\mathrm{ADHD}$ 를 동반하고 있 다고 하였다. 그리고 4학년인 Hyun 아동은 발음이 부정확하고 말 이 유창하지 못한 특징이 있었지만 공식적인 진단을 받은 적은 없 다고 하였다. 그리고 이외 5 명 아동은 읽기와 쓰기문제 이외에는 별 다른 문제가 없다고 보고되었다(Table 1).

\section{측정도구}

난독증 진단 검사에는 비언어성 지능검사(Korean Comprehensive Test of Nonverbal Intelligence-2 [K-CTONI-2]; Park, 2014)를 이용하여 지능을 평가하였다. 그리고 읽기와쓰기 능력을 평가하기 위하여 한국어 읽기검사(Korean Language-based Reading Assessment [KOLRA]; Pae, Kim, Yoon, \& Jang, 2015), 아동 간편 읽기 및 쓰기 발달 검사(Quick Assessment of Childhood Reading and Writing [QRW]; Kim, Jai, Jung, \& Kim, 2020)를 이용하였다. 그리 고 대상자들의 언어능력은 수용 - 표현 어휘력검사(Receptive \& Expressive Vocabulary Test [REVT]; Kim, Hong, Kim, Jang, \& Lee, 2009)를 이용하였으며, SSD를 동반한 아동에게는 우리말 조음·음 운평가 2 (Urimal Test of Articulation and Phonology 2 [U-TAP 2]; Kim, Shin, Kim, \& Ha, 2020)를 적용하여 추가 평가하였다. 이러한 검사도구에 대하여 자세히 살펴보면 다음과 같다.

비언어성 지능검사(K-CTONI-2)

K-CTONI-2 (Park, 2014)는 만 5세 0개월부터 성인까지의 연령집

Table 2. Participants' character: gender and grade $(N=9)$

\begin{tabular}{lc}
\hline Character & $\mathrm{N} /$ Year $(\%)$ \\
\hline Gender of children & $\mathrm{N}(\%)$ \\
Male & $6(66.67)$ \\
Female & $3(33.33)$ \\
Grade (mean age) & Year $(\%)$ \\
1st (7;02) & $4(44.44)$ \\
2nd $(8 ; 07)$ & $2(22.22)$ \\
4th $(10 ; 03)$ & $3(33.33)$
\end{tabular}


단을 대상으로 한다. 지시문과 함께 제시된 도형과 그림을 이해하 고, 정답을 손으로 가리킬 수 있는 능력이 있으며 심각한 수준의 시 각 장애가 있는 사람을 제외하였을 때, 소검사 예제 문항 중 하나 이상에 정반응을 한 사람에게 실시한다. 즉, K-CTONI-2는 비언어 성 지능검사이며, 청각장애 또는 언어에 영향으로 정확한 지능검사 결과 도출이 어려운 경우에 활용될 수 있다.

그리고 그림과 도형을 이용하여 6 가지 소검사를 측정하는 것으 로 그림을 이용한 검사는 그림유추, 그림범주, 그림순서의 3 가지이 며, 도형을 이용한 검사는 도형유추, 도형범주, 도형순서 3 가지로 구성되어 있다. 6 개의 소검사 각각 25 문항으로 구성되어 있으며, 소 검사별로 연속해서 3 문항에 오답을 하였을 때 검사를 중단한다. 그 리고 천정문항 전까지 맞춘 정답에 각각 1 점씩 준다. 각 소검사 점 수는 표준점수(발달연령, 백분위, 환산점수)로 변환하며, 각 소검 사의 환산점수는 또 다른 표준점수인 3가지 종합척도(그림척도, 도 형척도 및 전체척도)별 종합점수로 합산하여 전체 백분위 등급과 지능지수를 구한다. 지능지수 결과 110 이상은 평균상에 속하며, 90-110은 평균, 80-89는 평균하, 70-79는 경계선의 지능으로 구분 하였다.

본 검사에는 시간 제한이 없으나, 일반적으로 6 가지 소검사를 모 두 실시하기 위해서는 40-60분이 소요된다. 그리고 각 소검사의 시 행은 각각 5-10분 정도가 소요된다. 이번 연구에서는 평가의 간편 성을 위해 6 개의 소검사 중 도형유추, 도형범주, 도형순서와 같은 3 가지 동형검사만을 진행하고 그 환산점수를 구해 지능지수를 구 하였다. 그러므로 이번 연구에서 비언어성 지능검사는 평균 20 분 정도 소요되었다.

\section{수용·표현 어휘력검사(REVT)}

REVT (Kim et al., 2009)는 언어능력 중 어휘능력 부분을 측정 하는 것으로, 만 2 세 6 개월부터 만 16 세 이상 성인까지 평가 가능하 다. 어휘능력은 수용어휘능력과 표현어휘능력으로 구분하여 측정 하도록 되어있으며, 어휘발달 수준에 대한 백분위 점수를 제공하 여 같은 생활연령대의 상대자들과 비교하였을 때 상대적인 어휘 발 달수준을 제시해주고 있다.

수용어휘와 표현어휘 각각 어휘 문항 수는 185 개이며, 연습문항 을 실시하여 연구 대상자가 검사방법에 익숙해지도록 한 후에, 생 활연령에 따라 시작문항을 달리한다. 검사는 표현어휘검사부터 실 시하고, 표현어휘검사에서 설정된 기초선(baseline) 번호를 시작문 항 번호로 한다. 검사는 최고한계선(ceiling) 문항까지 실시하는 것 을 원칙으로 하며, 대상자가 연속적으로 8 문항 중 6 개를 틀리게 반 응하면 검사를 중지한다. 올바르게 응답한 문항에 대하여 1 점을 부
여하여 원점수를 구하고 이에 따른 등가연령 및 백분위 점수를 산 출할수 있다.

검사 결과는 규준에 제시된 생활연령에 해당하는 수용어휘능력 과 표현어휘능력의 평균, 표준편차 점수를 기준으로 '정상 발달' ‘약간 지체/유의 요망' 및 ‘어휘능력 발달지체’로 크게 나누어 판정 한다.

대상자의 어휘수준에 따라 소요되는 시간은 다르다. 즉, 어휘수 준이 높을수록 연령수준보다 어려운 어휘에 대하여 정반응을 보이 므로, 최고한계선 문항까지 도달하는데 더 많은 시간이 소요된다. 이번 연구에 참여한 초등학생 대상자들은 평균 30 분 정도가 소요 되었다.

\section{한국어 읽기검사(KOLRA)}

KOLRA (Pae et al., 2015)는 한국어에 대한 읽기와 쓰기 능력을 평가하는 표준화된 도구이다. 평가내용을 크게 구분하였을 때는 1) 읽기 선별검사, 2) 핵심검사(해독, 읽기이해, 문단글 읽기 유창성, 듣기이해), 3) 상세검사(음운인식, 빠른 이름대기, 음운기억, 받아쓰 기, 주제글 쓰기)로 구분되어 있으며, 각 평가 영역별로 구별하면 10 가지 소검사를 포함하고 있다(Table 3). KOLRA 검사의 주요 목적 은 하위검사를 통해 읽기장애 유무 및 읽기 하위 영역의 강 - 약점 을 파악하고자 하는 것이다.

검사 영역별로 구분하였을 때, 선별검사는 아동을 읽기진단검사 에 의뢰해야 하는지 빠른 시간 안에 파악해야 할 때 실시하는 검사 이며, 핵심검사는 읽기장애 유무 및 유형을 파악하는 데 필요한 검 사로 진단을 위해서는 검사 대상에게 모두 실시하여야 하는 검사이 다. 상세검사는 핵심검사에서 드러난 해독의 문제가 음운처리능력 과 관련하여 있는지 살펴보거나 읽기와 함께 학습에 중요한 능력이 되는 쓰기 수행 능력을 살펴볼 때 추가로 실시하는 검사이다.

주요 검사 대상자는 초등학교 1학년부터 6학년까지이지만, 연령 과 상관없이 읽기와 쓰기능력이 초등학교 수준일 경우는 사용할 수 있다. 검사는 선별검사 5분 내외, 핵심검사 약 20-30분, 상세검사 30 분 내외로 소요되며 아동의 수행능력에 따라 소요 시간에 차이가 있 지만 초등학교 저학년의 경우 90 분 정도의 소요시간이 필요하였다.

원점수 검사 결과를 온라인 코드를 이용하여 기입하면 표준점 수와 백분위수가 제공되며, 핵심검사인 해독, 읽기이해, 문단 글 읽 기 유창성 중 어느 한 하위 영역에서라도 표준점수가 70점 이하로 나타나면 심한 읽기 부진으로 해석하였다. 읽기 이해력이 낮은 경 우(표준점수 90 이하)에는 해독과 듣기이해 표준점수를 확인하여, 해독에서만 문제를 보이는 아동인 경우 '난독증(dyslexia)'일 가능 성이 높으며, 해독에는 문제가 없으나 듣기이해에서 문제를 보이는 
Table 3. Sub-tests, contents, and the number of items of KOLRA

\begin{tabular}{|c|c|c|c|c|c|}
\hline Sub-tests & \multicolumn{4}{|c|}{ Contents } & $\begin{array}{l}\text { N. of } \\
\text { items }\end{array}$ \\
\hline \multicolumn{5}{|c|}{$\begin{array}{l}\text { Screening: Question- If any of the questions are marked "Yes", proceed with the key and detailed inspection } \\
\text { naire of reading }\end{array}$} & 10 \\
\hline \multirow[t]{9}{*}{ Key assessment } & \multirow[t]{3}{*}{ 1. Decoding } & Meaning word & \multicolumn{2}{|c|}{$\begin{array}{l}\text { Grapheme-phoneme correspondent words } \\
\text { Grapheme-phoneme non-correspondent words }\end{array}$} & $\begin{array}{l}20 \\
20\end{array}$ \\
\hline & & Nonsense word & \multicolumn{2}{|c|}{$\begin{array}{l}\text { Grapheme-phoneme correspondent words } \\
\text { Grapheme-phoneme non-correspondent words }\end{array}$} & $\begin{array}{l}20 \\
20\end{array}$ \\
\hline & & \multicolumn{3}{|l|}{ Total raw score of decoding } & 80 \\
\hline & \multirow[t]{2}{*}{ 2. Reading comprehension } & \multicolumn{3}{|l|}{ Reading sentences and filling in empty spaces } & 24 \\
\hline & & \multicolumn{3}{|l|}{ Total raw score of reading comprehension } & 24 \\
\hline & \multirow[t]{2}{*}{ 3. Paragraph reading fluency } & \multicolumn{3}{|c|}{ To measure the speed at which a paragraph is read } & 7 \\
\hline & & \multicolumn{3}{|c|}{ Total raw score: (Number of correctly reading syllables/spent time)×10 } & \\
\hline & \multirow[t]{2}{*}{ 4. Listening comprehension } & \multicolumn{3}{|c|}{ Listening to the 3 story and answering questions assignment } & 18 \\
\hline & & \multicolumn{3}{|c|}{ Total raw score of listening comprehension } & 18 \\
\hline \multirow[t]{23}{*}{ Detailed assessme } & 5. Phonological awareness & \multirow[t]{4}{*}{ Phonemic deletion } & \multicolumn{2}{|c|}{ Syllable deletion } & 5 \\
\hline & & & \multirow[t]{3}{*}{ Phoneme } & Initial(beginning) consonant deletion & 4 \\
\hline & & & & Final consonant deletion in body-coda & 4 \\
\hline & & & & Initial consonant deletion in a word & 2 \\
\hline & & \multirow[t]{4}{*}{ Phonemic synthesis } & \multicolumn{2}{|c|}{ Syllable synthesis (2, 3 syllable words) } & 4 \\
\hline & & & Phoneme & CV & 4 \\
\hline & & & & CVC & 4 \\
\hline & & & & CVCV, CVCVC & 2 \\
\hline & & \multicolumn{3}{|l|}{ Total raw score of phonological awareness } & 30 \\
\hline & 6. Rapid naming & \multicolumn{3}{|l|}{ Digit naming } & 50 \\
\hline & & \multicolumn{3}{|l|}{ Letter (CV syllable) naming } & 50 \\
\hline & & \multicolumn{3}{|c|}{ Total raw score of rapid naming: (spent time of digit +letter)/2 } & \\
\hline & 7. Phonological memory & \multicolumn{3}{|c|}{2 syllables (raw scores: the number of syllables recalled) } & 5 \\
\hline & & 3 syllables (raw scores: the number of sylla & ecalled) & & 5 \\
\hline & & 4 syllables (raw scores: the number of sylla & ecalled) & & 5 \\
\hline & & 5 syllables (raw scores: the number of sylla & ecalled) & & 5 \\
\hline & & Total raw score of phonological memory & & & 70 \\
\hline & 8. Writing I: Dictation & Words (2-4 syllables) & & & 9 \\
\hline & & Sentences (raw scores: 21 phrases) & & & 6 \\
\hline & & Total raw score of dictation & & & 30 \\
\hline & 9. Writing II: Topic article & Content & & & 8 \\
\hline & & Format & & & 8 \\
\hline & & Total raw score of writing article & & & 16 \\
\hline
\end{tabular}

CV= consonant+vowel; KOLRA=Korean Language-based Reading Assessment (Pae et al., 2015).

아동인 경우 ‘특정이해결함(specific comprehension deficit)'일 가 능성이 높다고 보았다. 그리고 해독과 듣기이해 모두에서 문제를 보 이는 아동은 '혼합형(mixed dyslexia)'일 가능성이 높다고 보았으 며, 해독, 듣기이해에서 문제를 보이지 않으나 읽기이해에서 문제를 보이는 아동인 경우 '비특정읽기장애(non-specific reading disorder)'일 가능성이 높다고 하였다. 이러한 진단 내용과 해석을 참고 하여 이번 연구에서는 KOLRA의 모든 평가항목을 검사에 포함하 였다(Table 3).

\section{아동 간편 읽기 및 쓰기발달 검사(QRW)}

QRW (Kim, Jai et al., 2020)는 아동의 읽기와 쓰기발달 능력을 평가하기 위해 개발되었으며, 만 5세부터 초등학교 4학년까지의 읽 기와 쓰기 능력을 평가할 수 있도록 구성하였다.

평가 내용은 1) 음운조작능력(음운인식: 2음절 낱말 음절합성과 분리, 1 음절 낱말의 종성합성과 분리, 1 음절 낱말 음소분리 및 합 성), 2) 읽기(모음자 읽기[단모음, 이중모음], 자음자 읽기, 2음절 이 하 의미단어읽기, 2 음절 이하 무의미단어읽기, 의미단어로 구성된 
Table 4. Sub-tests, contents, and the number of items of QRW

\begin{tabular}{|c|c|c|c|c|}
\hline \multirow{3}{*}{$\begin{array}{l}\text { Sub-tests } \\
\text { Phonological } \\
\text { awareness }\end{array}$} & \multirow{3}{*}{ Syllables } & \multicolumn{2}{|l|}{ Contents } & \multirow{2}{*}{$\frac{\text { N. of items }}{2}$} \\
\hline & & Two syllables & Blending of syllables & \\
\hline & & & Segmentation of syllables & 2 \\
\hline & Phoneme & Final consonant in body-coda (CV-C) & Final consonant blending in one syllable word & 2 \\
\hline & & & Final consonant deletion in /CVC/ one syllable word & 2 \\
\hline & & /CVC/ & Phoneme segmentation (one syllables words) & 2 \\
\hline & & & Phoneme blending (one syllables words) & 2 \\
\hline & & Total raw score of phonological awareness & & 12 \\
\hline \multirow[t]{10}{*}{ Reading } & Grapheme & Vowels & Single vowels naming & 8 \\
\hline & & & Diphthong naming & 11 \\
\hline & & Consonants & Consonants naming & 19 \\
\hline & Word & Words reading (one or two syllables) & & 3 \\
\hline & & Non-words reading (one or two syllables) & & 3 \\
\hline & Sentence & Sentences reading & & 6 \\
\hline & & Non-sentences reading & & 3 \\
\hline & & Phrases & Words phrase reading & 21 \\
\hline & & & Non-words phrase reading & 7 \\
\hline & & Total raw score of reading & & 72 \\
\hline \multirow[t]{6}{*}{ Writing } & Words (one syllables) & /CV/ words dictation & & 11 \\
\hline & Sentences & Sentence dictation & & 9 \\
\hline & & Phrases dictation & Dictation without phonological process & 8 \\
\hline & & & Dictation of phrases of phonological process & 21 \\
\hline & & Phonemes dictation & & 223 \\
\hline & & Total raw score of writing & & 40 \\
\hline
\end{tabular}

QRW = Quick Assessment of Childhood Reading and Writing (Kim, Jai et al., 2020).

2-5어절 문장읽기, 무의미단어로 구성된 2-3음절 문장읽기), 3) 쓰 기(받침이 없는[음운변동 없는] 1음절 낱말 듣고 받아쓰기, 음운변 동 낱말이 포함된 2-4어절 문장 듣고 받아쓰기)로 구성되어 있다 (Table 4).

KOLRA가 초등학교 1학년부터 검사가 가능한 것과는 달리, QRW는 만 5세 이상의 아동을 대상으로 읽기와 쓰기 능력을 살펴 보는 검사이기에 음운인식 및 읽기와 쓰기에 대한 평가에 있어 더 빠르게, 낮은 단계의 부분도 평가하여 살펴볼 수 있게 되어 있다. 즉, 음운인식 부분에 있어 구성은 KOLRA와 유사하지만 제시 문 항수가 적고, 단모음과 이중모음, 자음자 읽기와 같은 가장 기초적 인 음운능력을 측정하는 부분이 추가되어 있다. 그리고 의미단어 와 무의미단어에 대한 읽기능력을 단어읽기가 아닌 문장 읽기를 통 해 살펴볼 수 있게 하여 한글의 음운변동 오류에 대해 좀 더 자연스 러운 조건에서 평가하도록 하였다. 쓰기에 있어서는 받침이 없는 1음절 낱말부터 쓰기 능력을 평가하도록 하여 자음과 모음결합의 가장 기초적인 쓰기를 평가할 수 있도록 하였다.

이러한 평가의 간편성과 어린 연령 집단을 고려한 평가내용을 참 고하여, 음운인식 능력 및 읽기능력이 저조한 것으로 알려진 이번
연구의 난독증 대상자에게도 QRW를 읽기와 쓰기에 대한 추가 평 가에 적용하였다(Table 4).

\section{우리말 조음·음운평가 2 (U-TAP 2)}

U-TAP 2 (Kim, Shin et al., 2020)는 우리말에 대한 말소리 산출 정확성 능력을 측정하는 것이다. 말소리 산출 능력에 대한 평가는 30 개 단어 이름대기와 11 개 문장(47개 어절) 따라 말하기 과제로 구분되어 있다. 단어 이름대기 과제는 그림을 보여주고 대상자가 자발적으로 그림으로 제시된 단어의 이름대기를 하는 과제이며, 문장 따라 말하기 과제는 그림과 함께 4어절 이내 문장을 들려준 후 대상자가 문장을 따라 말하게 하는 과제이다.

단어 이름대기와 문장 따라 말하기 과제는 다음과 같은 절차에 의해 분석되었다. 1) 대상자의 발음을 전사 기록하고, 2) 단어에 포 함된 19 개 자음과 7 개 단모음 말소리를 어절 및 음절 위치(어두초 성, 어중초성, 어중종성, 어말종성)에 따라서 말소리 오류 패턴(정 조음, 대치, 왜곡, 생략)을 기록하였다. 그리고 기록한 내용을 통해 3) 분절음단위에서 음소정확도는 자음정확도(percentage of correct consonants, PCC)와 모음정확도(percentage of vowels correct, 
PVC)를 계산하여 연령 규준과 비교하였다. 4) 이외에 단어단위의 분석에서는 평균음운길이(phonological mean length of utterance, $\mathrm{PMLU}=$ [분절음수+정조음한 자음수]/전체 어절 수; 대상자가 산 출한 분절음 수와 정확하게 조음한 자음의 수를 더하여 계산), 단 어단위 근접률(proportion of whole-word proximity, $\mathrm{PWP}=$ 아동 의 PMLU/목표발화PMLU; 대상자가 목표 단어와 얼마나 유사하 게 말소리를 산출하였는지 보여주는 지표로, 성인이 산출한 PMLU 와 아동이 산출한 PMLU의 비율을 의미함), 단어단위 정확률(proportion of whole-word correctness, $\mathrm{PWC}=$ 정확하게 산출한 어절 수/전체 어절 수; 대상자가 산출한 전체 단어 중에서 정확하게 발음 한 단어의 비율을 측정)의 3 가지 측정치를 산출하여 비교할 수 있 도록 하였지만 이번 연구에는 이러한 추가분석은 하지 않았다. 그 리고 5) 문장수준에서는 문장 내에 포함된 19 개 자음과 7 개 단모음 말소리에 대한 PCC를 구하였다.

\section{연구절차}

서울시교육청 서울학습도움센터는 서울시내 공립학교에 재학 중인 난독증 아동에 대한 치료지원 방안을 마련하기 위하여 2019 년 10 월 서울소재 대학교 언어병리학과와 치료협력기관 협정을 거 쳐, 2019년 11월 1일에 난독증 의심 아동 9명에 대한 명단을 치료협 력기관 언어재활사감독자에게 전달하였다.

이후 언어재활사 감독자 1 인은 11 월 첫째 주에는 대상 아동의 담 임선생님과 전화상담을 통해 아동의 현재 읽기와 쓰기 수준에 대 한 내용을 확인하고, 학교 내 치료공간을 정하였다. 이후 대상자의 부모님 또는 보호자와 통화하여 아동의 읽기 및 쓰기 수준 확인, 치료이력과 동반장애 유/무, 이외 가족 상황을 통한 유전적 소견 등 에 대해 전화상담을 진행하고 치료 요일과 시간(주 1 회, 2회기[80분]) 을 정하였다. 이러한 9명 난독증 의심 대상자의 담임선생님과 보호 자와의 전화상담 내용은 따로 기록하여, 대상자의 학교로 직접 찾 아가서 치료 가능한 6명 언어재활사에게 아동 정보, 학교정보, 그리 고 치료시간을 전달하였다. 진단 및 치료장소는 처음에는 교내 상 담실로 정하였으나, 학교 내 사정에 따라서 대상자의 교실, 상담실 등으로 변경하여 고정된 장소에서 개별치료가 이루어지도록 하였 다. 그리고 치료시간은 대상자의 학교 수업이 모두 종료하고 교실 정돈이 마무리된 시간대로 정하였는데, 학년 별, 학교 별로 약간의 차이는 있지만 보통 1:30-3:00 사이에 치료가 시작되도록 하였다.

11 월 둘째 주에는 난독치유 프로그램에 참여하는 6명 언어재활 사가 모두 모여, 회의를 통해 9명 난독증 의심 대상자의 정보를 공 유하고 진단 검사도구에 대한 목록과 평가방법을 공유하였다. 11월 셋째 주부터 넷째 주까지는 언어재활사가 난독증 의심 대상자가 재
학중인 초등학교로 찾아가 지정장소에서 초기 진단 평가(비언어성 지능, 어휘능력평가, 읽기 \& 쓰기능력 평가, 음운인식능력, 음운기 억, 조음·음운평가[필요한 아동에게])를 진행하였다. 초기진단에 서 비언어성 지능점수와 KOLRA 해독과 유창성 평가 결과는 불일 치모델과 IQ 절단점 접근법에 적용하여 난독증 여부를 진단하였 다. 그리고 11 월 넷째 주부터 2월 말까지 총 25회기의 난독 언어치료 를 진행하였다. 치료 3개월 종료시점에 맞추어 2019년 2월에는 KO$\mathrm{LRA}$ 와 QRW를 재평가하였다. 그리고 KOLRA 또는 QRW (KOL$\mathrm{RA}$ 재평가가 어려웠던 대상자 1 명)에서 해독과 유창성의 재평가 결과를 통해 RTI 진단모델을 적용하여 난독증 여부를 평가하였다 (Figure 2).

난독증 대상자의 동반장애에 대한 부분은 부모님과 상담을 통 해 대상자 2 명이 $\mathrm{ADHD}$ 진단을 받은 것을 알게 되었다. 그리고 대 상자의 어휘능력 평가 결과와 대상자의 학령전기 치료이력 상담을 통해 $\mathrm{DLD}$ 를 구분할 수 있었다. 그리고 언어 평가와 읽기능력 평가 중 대상자의 말소리의 불명료함을 확인하여 U-TAP 2 평가 결과 $\mathrm{SSD}$ 동반을 확인하였다. 그리고 또 다른 대상자는 REVT 평가 중 수용어휘능력에 비하여 표현어휘능력이 지체 수준이었으며 정확

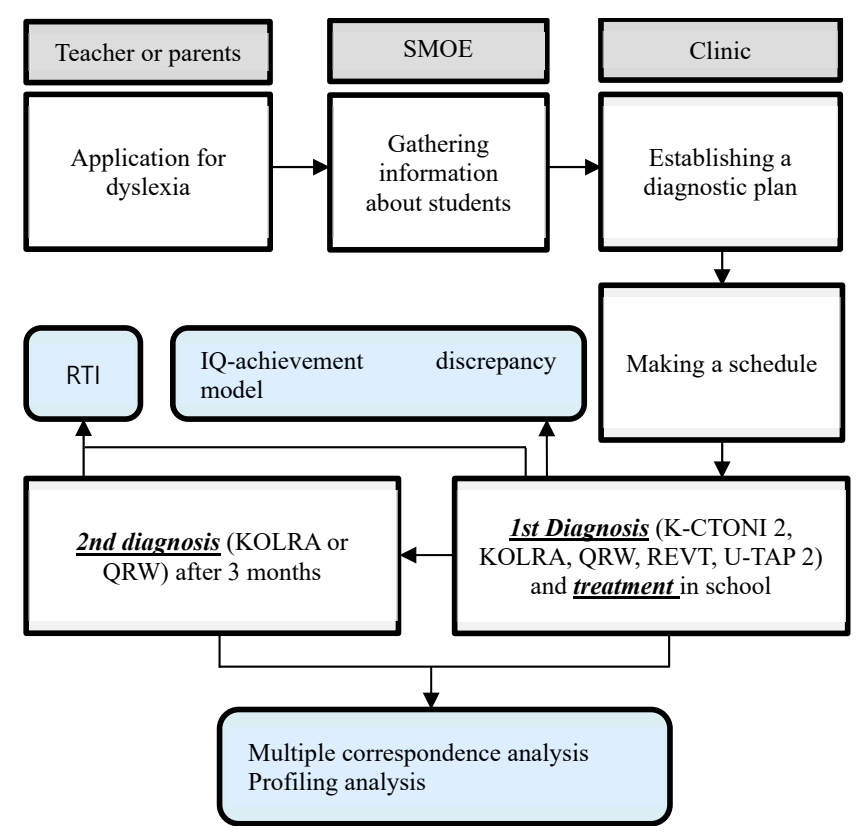

Figure 2. The research progresses.

I0 = intelligence quotient; K-CTONI-2 = Korean Comprehensive Test of Nonverbal Intelligence-2 (Park, 2014); KOLRA=Korean Language-based Reading Assessment (Pae et al., 2015); REVT = Receptive \& Expressive Vocabulary Test (Kim et al., 2009); RTI= response to intervention; QRW = Quick Assessment of Childhood Reading and Writing (Kim, Jai et al., 2020); SOME=Seoul metropolitan office of education; U-TAP $2=$ Urimal Test of Articulation and Phonology 2 (Kim, Shin et al., 2020). 
한 어휘에 대해 말 산출을 어려워하며 “그거요. 그거 있잖아요.”를 되풀이하는 현상을 기준으로 TOT 동반을 확인하였다.

이후 이와 같이 진행된 난독증 의심 대상자 9 명 아동에 대한 초 기 진단 평가 결과 데이터를 이용하여, 2 가지 진단모델(지능-성취 불일치모형, 지능절단점 접근법)을 적용한 난독증 진단을 실시하 였다. 그리고 9 명 대상자들에 대한 음운인식과 해독 중심의 읽기 중 재를 3개월간 진행하고 KOLRA와 QRW를 통해 읽기능력 진전도 를 평가하였다. 이때 신종 코로나 바이러스 감염증(corona virus disease 2019: COVID-19, WHO, 2020) 확산의 문제에 의해 대상자 들과 접근이 어려워졌다, 이러한 이유로 읽기능력 재평가에 사용된 KOLRA와 QRW를 모두 평가하지 못하고 KOLRA는 5명 아동에 게 $\mathrm{QRW}$ 는 8명 아동에게 재평가되었다. 그리고 이러한 읽기능력 재 평가 결과 읽기능력 진전도를 바탕으로 RTI 모델을 적용한 난독증 진단을 진행하였다.

그리고 3 가지 진단모델의 난독증 진단 결과와 대상자의 동반장 애 또는 동반증상과의 연관성을 단순 및 다중상응분석하고, 그 결 과에 따라 난독증 집단을 구분하여 읽기관련 측정변수들을 프로 파일 분석하였다(Figure 2).

\section{진단모델별 난독증 조작적정의}

3 가지 대표적 난독증 진단모델 중 지능-성취 불일치모형은 학교 교육관련자와 연구자들이 난독증을 진단하기 위하여 정상적인 지
능수준에 비하여 읽기능력이 저조한 대상자를 난독증으로 진단하 는 모델로 초기부터 사용되었다. RTI 모델은 불일치모형의 단점을 보완하여 학교 및 학교관련 기관에서 특수교육 대상자를 선별하는 데 읽기관련 중재를 적용한 후 중재효과가 저조한 대상자만을 선택 하여 특수교육 대상자로 선정하기 위해 사용한 모델이다. 그리고 지능절단점 접근법 또한 불일치모형의 단점을 보완하기 위하여 평 균적인 지능부분에 대한 정의 수준을 낮추어 적용한 모델이다(Adlof \& Hogan, 2018). 이처럼 진단모델별로 난독증을 진단하는 목적 은 다르고 이에 따라 그 진단 기준 또한 다르게 정의되었다. 이 번 연구에서는 지능-성취 불일치모형, RTI 모델, 지능절단점 접근법과 같은 대표적인 난독증 진단모델 3 가지 기준에 대한 조작적 정의를 개별 모델의 접근법에 따라 다음과 같이 구분하였다(Table 5).

첫째, 지능-성취 불일치모형에 있어서 난독증은 언어성과 동작 성을 합한 전체지능 점수가 평균적인 것에 비하여 표준화 검사에 서 읽기정확성과 유창성이 또래에 비하여 낮은 수행을 보이는 대상 자들을 지칭한다. 이에 이번 연구에서는 비언어성지능 검사인 KCTONI 환산점수가 90 이상, 언어능력 수준인 REVT는 또래 평균 $-1 \mathrm{SD}$ 이상이지만, KOLRA의 해독과 유창성 표준화점수가 90 보다 작은 대상자들을 난독증으로 구분하였다. 둘째, RTI 모델은 평균 적인 지능의 대상자 중에 읽기능력이 저조한 대상자들에게 집중적 인 증거기반 읽기교수를 3 개월 이상 진행한 후에도 읽기성취도와 중재 진전도가 낮은 대상자들을 난독증으로 정의하고 있다. 이에

Table 5. Operationalizing the definition of dyslexia by diagnostic model

\begin{tabular}{|c|c|c|c|}
\hline & I0 achievement discrepancy approach & RTI & IQ cutoff approach \\
\hline Purpose & Diagnosis for educational or research & To select subjects for special education service & $\begin{array}{l}\text { Somewhat more liberal approach to diagnosing } \\
\text { dyslexia }\end{array}$ \\
\hline Definition & $\begin{array}{l}\text { Subjects were considered to have dyslexia when } \\
\text { their word reading skills, as measured by norm- } \\
\text { referenced measures of word reading speed or } \\
\text { accuracy, were "discrepant" from their intelli- } \\
\text { gence }\end{array}$ & $\begin{array}{l}\text { It was allowed for identification of learning dis- } \\
\text { abilities based on a student's failure to respond } \\
\text { to scientifically based instruction }\end{array}$ & $\begin{array}{l}\text { Children with dyslexia had low word reading in } \\
\text { the presence of "normal" intelligence with no } \\
\text { stipulation of a discrepancy between IO and } \\
\text { word reading abilities }\end{array}$ \\
\hline \multirow[t]{2}{*}{ Potential } & $\begin{array}{l}\text { Full-scale IO score (composite of both verbal and } \\
\text { nonverbal IO scores) }\end{array}$ & Average intelligence and adequate instruction & $\begin{array}{l}\text { Nonverbal IQ measures and liberal cutoff (within } \\
2 \text { SDs of the mean) }\end{array}$ \\
\hline & $\begin{array}{l}\text { - K-CTONI } \geq 90 \\
\text { - REVT: within -1 SD of the mean }\end{array}$ & - K-CTONI $\geq 90$ & - K-CTONI $\geq 80$ \\
\hline \multirow[t]{4}{*}{ Performing evidence } & $\begin{array}{l}\text { Norm-referenced measures of word reading } \\
\text { speed or accuracy }\end{array}$ & $\begin{array}{l}\text { Making adequate progress in response to evi- } \\
\text { dence-based instruction in the regular educa- } \\
\text { tion system }\end{array}$ & Word reading \\
\hline & - $\mathrm{D}$ and $\mathrm{PRF}$ in $\mathrm{KOLRA}<90$ & - $\mathrm{D}$ and $\mathrm{PRF}$ in $\mathrm{KOLRA}<90$ & - $\mathrm{D}$ and $\mathrm{PRF}$ in KOLRA <90 \\
\hline & & - Reading in $\mathrm{QRW}<70$ & \\
\hline & & $\begin{array}{l}\text { - Decoding or reading progress in KOLRA or } \\
\text { QRW }<45 \%\end{array}$ & \\
\hline
\end{tabular}

$\mathrm{D}=$ decoding; $\mathrm{IQ}=$ intelligence quotient; K-CTONI-2 = Korean Comprehensive Test of Nonverbal Intelligence-2 (Park, 2014); KOLRA=Korean Language-based Reading Assessment (Pae et al., 2015); PRF= Paragraph reading fluency; Re=reading; REVT=Receptive \& Expressive Vocabulary Test (Kim et al., 2009); RTI= response to intervention; QRW= Quick Assessment of Childhood Reading and Writing (Kim, Jai et al., 2020). 
이번 연구에서는 K-CTONI 환산점수 90 이상인 대상자 중 3 개월 의 집중적인 읽기중재가 진행된 후에 KOLRA의 해독과 유창성 표 준화점수가 90 보다 작거나 $\mathrm{QRW}$ 의 읽기 원점수가 70점보다 작으 며, KOLRA의 해독점수 진전률([중재후-전]/중재전)과 QRW 읽기 점수 진전율이 $45 \%$ 이하인 대상자로 한정하였다. 셋째, 지능절단점 접근법에서는 평균적인 지능의 범위를 $-2 \mathrm{SD}$ 이상으로 정하고 이러 한 폭넓은 환산 지능점수대에서 읽기능력이 저조한 대상자들을 난 독증으로 정의하고 있다. 이에 이번 연구에서는 K-CTONI 환산점 수는 80 이상, KOLRA 초기평가에서 해독과 유창성 표준화점수가 모두 90보다 작은 대상자들을 지능절단점 접근법을 적용한 난독 증으로 정의하였다(Table 5).

\section{자료분석}

수집된 data는 IBM SPSS 25.0와 Excel (Office 365)을 이용하여 분석하였다.

연구문제 1은 대상자를 난독증 진단모델(불일치모델, RTI, IQ 절 단점 접근) 적용에 따른 난독증 진단 결과 여부와 동반장애(청각적 정보처리 문제, 작업기억 용량문제, 유전적 요인, $\mathrm{ADHD}, \mathrm{DLD}$, SSD) 연관성을 SPSS 25.0 을 이용하여 단순상응분석(Simple correspondence analysis, $\mathrm{SCA}$ )과 다중상응분석(Multiple correspondence analysis, MCA)을 통해 살펴보았다. 상응분석은 변수들의 연관성을 분석하여 그 결과를 시각적 해석이 용이하도록 기하학적 맵(map)으로 제시하는 다변량 통계기법이다. 즉, SCA와 $\mathrm{MCA}$ 는 다차원척도법과 같이 일종의 수치정보를 그림으로 요약해서 표현 하는 방법으로, 정보를 시각화(visualization)하여 표현하는 것으 로 응답의 수에 따라 단순과 다중으로 분류하였다.

그리고 연구문제 2 는 대응분석 결과에 의해 구분된 집단 별 음 운 \& 인지처리, 음운기억, 언어능력(어휘능력, 듣기/읽기이해, 쓰기) 을 Excel을 이용하여 프로파일 분석하였다.

\section{연구결과}

\section{진단모델별 난독증 진단과 동반장애(증상)}

초기 평가 전에 어머님과의 전화상담을 통해 대상자의 동반장애 여부를 확인하고, 초기 평가에서는 9명 대상자의 비언어성지능 검 사, 어휘능력, 읽기 및 쓰기 능력, 또는 조음·음운 능력을 측정하였 다. 그리고 초기평가 결과를 통해 대상자의 추가 동반장애 및 증상 을 확인하였다(Table 6). 이후 3 개월 간 읽기관련 중재를 진행한 후 에 9명 대상자의 읽기능력을 재평가하여 중재 효과 진전도를 계산 하였다(Table 7). 이후초기평가 결과와 동반장애와 증상, 중재효과
에 대한 재평가 결과 진전도 자료를 이용하여 9명 대상자에게 난독 증 진단모델별 난독증 여/부 진단과 동반장애 및 증상을 확인하였 다(Table 8). 이러한 난독증 진단과 동반장애 또는 증상에 대한 결 과는 Tables $6,7,8$ 에 제시하였다.

\section{읽기관련 측정변인 초기평가 결과와 동반장애(증상) 확인}

9 명 대상자의 비언어성 IQ 평가결과 Jung $(8 ; 05, \mathrm{M}) 1$ 명 아동을 제외한 8명은 지능지수 평균 90 점 이상이었다. 그리고 8 명 대상자 중 $\mathrm{Da}(10 ; 04, \mathrm{M})$ 아동은 비언어성 IQ가 119 로 평균 이상이었다 (Table 6). 어휘능력을 측정한 결과는 저학년일수록 정상발달 어휘 능력을 보였다. 즉, 1학년 $\mathrm{Si}(6 ; 11, \mathrm{M}), \mathrm{Do}(7 ; 01, \mathrm{M})$, Tae $(7 ; 01, \mathrm{M})$ 3 명과 2학년 $\mathrm{Yu}(8 ; 09, \mathrm{~F})$ 아동은 또래와 유사한 평균수준의 표현 및 수용어휘 수준을 보였다. 그리고 1학년 Seung $(7 ; 09, \mathrm{M})$ 아동은 수어휘 능력이 또래 평균에 비하여 약간 지체되었다. 4학년 Hyun $(10 ; 00, \mathrm{~F})$ 과 $\mathrm{Da}(10 ; 04, \mathrm{M})$ 아동은 수용 및 표현어휘능력 모두가 약 간 지체되어 있었다. 그리고 2학년 Jung $(8 ; 05, \mathrm{M})$ 아동은 수용어휘 능력은 또래에 비하여 약간 지체, 표현어휘능력은 지체(또래 평균 $-2 \mathrm{SD}$ [표준편차] 이하)되어 있어 전체적인 언어능력은 지체되어 있 었다. 그리고 4 학년 Rae $(10 ; 07, \mathrm{~F})$ 아동은 표현 및 수용어휘능력 모 두가 또래 평균 $-2 \mathrm{SD}$ 이하로 지체되어 언어발달지체로 확인되었다.

읽기능력을 평가하는 KOLRA (Pae et al., 2015)의 초기평가 결과 4 가지 핵심검사 중 3 가지인 해독(decoding: D), 읽기이해(reading comprehension, RC), 문단글 읽기 유창성(paragraph reading fluency, PRF)에 대해 모든 대상자 9명이 표준점수 90점 이하로 100 점 평균을 기준으로 하였을 때 평균 하로 나타나, 모든 대상자는 유사 하게 매우 저조한 읽기능력 문제 특성을 보였다. 그리고 4 가지 핵심 검사 중 듣기 이해(listening comprehension, LC) 환산 점수결과는 $\mathrm{Yu}(8 ; 09, \mathrm{~F})$ 와 $\mathrm{Da}(10 ; 04, \mathrm{M})$ 는 평균하의 능력을 보였으며 나머지 $\mathrm{Si}$ (6;11, M), Do (7;01, M), Tae (7;01, M), Seung (7;09, M), Jung (8;05, $\mathrm{M})$, Hyun (10;00, F), 그리고 Rae (10;07, F) 7명은 평균적인 듣기 능 력을 보였다. 즉, KOLRA 규준안에 의해서 해석하면 $\mathrm{Yu}(8 ; 09, \mathrm{~F})$ 와 $\mathrm{Da}(10 ; 04, \mathrm{M})$ 는 혼합형 난독증으로 나머지 7명은 난독증으로 확 인되었다(Table 6).

KOLRA 핵심검사 결과를 세분화하여 살펴보면, 2음절 '자소-음 소 일치형/자소-음소 불일치형', ‘의미/무의미’ 낱말을 보고 읽기 능 력을 평가하는 해독(D) 능력에서, Seung $(7 ; 09, \mathrm{M})$ 과 Jung $(8 ; 05, \mathrm{M})$ 아동은 표준점수 17-19로 가장 낮은 해독능력을 보였으며, 다음으 로는 $\mathrm{Si}(6 ; 11, \mathrm{M}), \mathrm{Do}(7 ; 01, \mathrm{M}), \mathrm{Tae}(7 ; 01, \mathrm{M}), 3$ 명 아동이 23-27점의 저조한 해독능력을 보였다. 그리고 4학년인 Hyun $(10 ; 00, \mathrm{~F})$ 과 Rae $(10 ; 07, \mathrm{~F})$ 는 41,46 점의 유사한 해독능력을 보였고, 평균이상의 지 


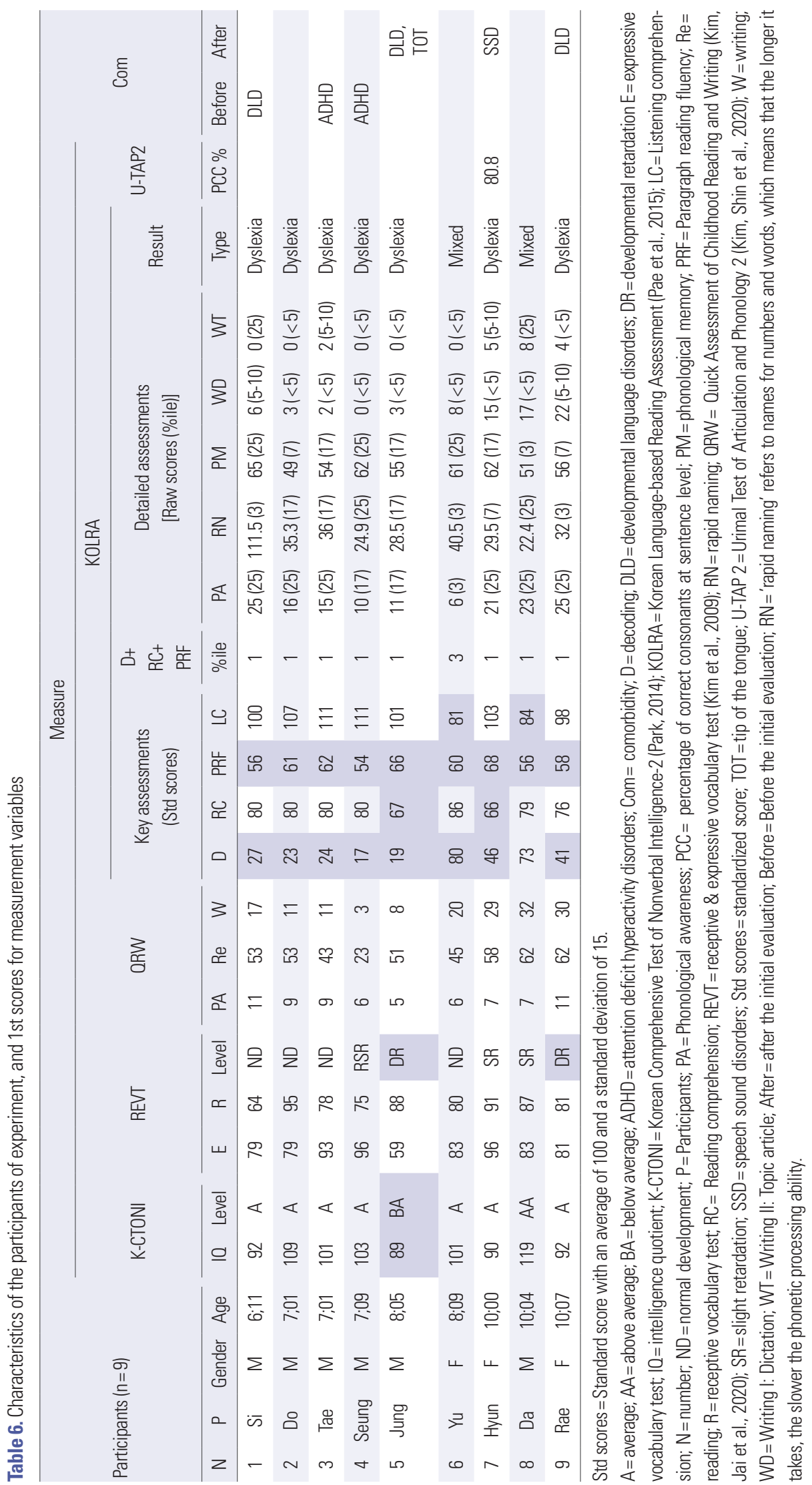


Table 7. Results of decoding, reading fluency, and reading progress (3 months later) for QRW and KOLRA

\begin{tabular}{|c|c|c|c|c|c|c|c|c|c|c|c|c|c|c|c|c|c|c|c|c|c|c|}
\hline \multirow{3}{*}{\multicolumn{4}{|c|}{ Participants $(n=9)$}} & \multicolumn{16}{|c|}{ Measure } & \multirow{2}{*}{\multicolumn{3}{|c|}{ Progress (\%) }} \\
\hline & & & & \multicolumn{6}{|c|}{ QRW } & \multicolumn{10}{|c|}{ KOLRA } & & & \\
\hline & & & & \multicolumn{3}{|c|}{$1 \mathrm{st}$} & \multicolumn{3}{|c|}{ 2nd } & \multicolumn{4}{|c|}{$\begin{array}{l}\text { 1st key assessments } \\
\text { (Std scores) }\end{array}$} & \multirow{2}{*}{ \%ile } & \multicolumn{4}{|c|}{$\begin{array}{c}\text { 2nd key assessments } \\
\text { (Std scores) }\end{array}$} & \multirow{2}{*}{ \%ile } & \multicolumn{2}{|c|}{ KOLRA } & \multirow{2}{*}{$\begin{array}{c}\text { QRW } \\
\text { Re }\end{array}$} \\
\hline N & P & $\begin{array}{l}\text { Gen- } \\
\text { der }\end{array}$ & Age & PA & Re & W & PA & Re & W & $\mathrm{D}$ & $\mathrm{RC}$ & PRF & LC & & $D$ & $\mathrm{RC}$ & PRF & LC & & D & $\begin{array}{l}\text { (D+ } \\
\text { PRF) }\end{array}$ & \\
\hline 1 & $\mathrm{Si}$ & M & $6 ; 11$ & 11 & 53 & 17 & 12 & 66 & 20 & 27 & 80 & 56 & 100 & 1 & & & & & & & & 24.53 \\
\hline 2 & Do & M & $7 ; 01$ & 9 & 53 & 11 & 8 & 54 & 12 & 23 & 80 & 61 & 107 & 1 & & & & & & & & 1.89 \\
\hline 3 & Tae & $\mathrm{M}$ & $7 ; 01$ & 9 & 43 & 11 & 12 & 64 & 21 & 24 & 80 & 62 & 111 & 1 & & & & & & & & 48.83 \\
\hline 4 & Seung & $\mathrm{M}$ & $7: 09$ & 6 & 23 & 3 & 6 & 32 & 6 & 17 & 80 & 54 & 111 & 1 & 20 & 80 & 54 & 119 & 1 & 15.79 & 4.23 & 39.13 \\
\hline 5 & Jung & M & $8 ; 05$ & 5 & 51 & 8 & 11 & 64 & 15 & 19 & 67 & 66 & 101 & 1 & 51 & 70 & 77 & 105 & 1 & 168.42 & 50.59 & 25.49 \\
\hline 6 & Yu & $F$ & $8 ; 09$ & 6 & 45 & 20 & 9 & 58 & 20 & 80 & 86 & 60 & 81 & 3 & 84 & 79 & 77 & 97 & 6 & 5.0 & 15.0 & 28.89 \\
\hline 7 & Hyun & $\mathrm{F}$ & $10 ; 00$ & 7 & 58 & 29 & 12 & 69 & 33 & 46 & 66 & 68 & 103 & 1 & 73 & 66 & 71 & 103 & 1 & 58.69 & 26.32 & 18.96 \\
\hline 8 & $\mathrm{Da}$ & M & $10 ; 04$ & 7 & 62 & 32 & & & & 73 & 79 & 56 & 84 & 1 & 106 & 79 & 64 & 93 & 7 & 45.20 & 31.78 & \\
\hline 9 & Rae & $\mathrm{F}$ & $10 ; 07$ & 11 & 62 & 30 & 12 & 69 & 37 & 41 & 76 & 58 & 98 & 1 & & & & & & & & 11.29 \\
\hline
\end{tabular}

Std scores $=$ Standard score with an average of 100 and a standard deviation of 15 .

$A=$ average; $A A=$ above average; $B A=$ below average; $D=$ decoding; $D R=$ developmental retardation $E=$ expressive vocabulary test; $K$-CTONI=Korean Comprehensive Test of Nonverbal Intelligence-2 (Park, 2014); KOLRA=Korean Language-based Reading Assessment (Pae et al., 2015); LC=Listening comprehension; $N=$ number; ND=normal development; $\mathrm{P}=$ Participants; $\mathrm{PA}=$ Phonological awareness; $\mathrm{PCC}=$ percentage of correct consonants at sentence level; $\mathrm{PM}=$ phonological memory; PRF=Paragraph reading fluency; $R$ = reading; $R=$ receptive vocabulary test; $R C=$ Reading comprehension; $R E V T=$ receptive \& expressive vocabulary test(Kim et al., 2009); RN= rapid naming; $Q R W=$ Quick Assessment of Childhood Reading and Writing(Kim, Jai et al., 2020); SR=slight retardation; Std scores=standardized score; Progress (\%)=(2nd evaluation score-1st evaluation score)/1st evaluation score.

Table 8. Results of application of dyslexic diagnostic model and comorbidity or accompanying symptoms

\begin{tabular}{|c|c|c|c|c|c|c|c|c|c|c|c|c|c|c|c|c|c|c|c|c|c|}
\hline \multirow{2}{*}{\multicolumn{4}{|c|}{ Participants $(\mathrm{n}=9$ ) }} & \multicolumn{11}{|c|}{ Measure } & \multirow{2}{*}{\multicolumn{3}{|c|}{ Progress (\%) }} & \multirow{2}{*}{\multicolumn{3}{|c|}{$\begin{array}{c}\text { Diagnosis result } \\
\text { of dyslexia }\end{array}$}} & \multirow{4}{*}{ Com } \\
\hline & & & & \multirow{3}{*}{\multicolumn{2}{|c|}{$\begin{array}{c}\text { K-CTONI } \\
\text { Score Level }\end{array}$}} & \multicolumn{3}{|c|}{ REVT } & \multicolumn{6}{|c|}{ KOLRA (1st Key inspection's standard score) } & & & & & & & \\
\hline \multirow{2}{*}{$\mathrm{N}$} & \multirow{2}{*}{$P$} & \multirow{2}{*}{$\begin{array}{l}\text { Gen- } \\
\text { der }\end{array}$} & \multirow{2}{*}{ Age } & & & \multirow{2}{*}{$E$} & \multirow[t]{2}{*}{ B } & \multirow{2}{*}{ Level } & \multirow{2}{*}{$\mathrm{D}$} & \multirow{2}{*}{$\mathrm{RC}$} & \multirow{2}{*}{ PRF } & \multirow{2}{*}{ LC } & \multirow{2}{*}{ Level } & \multirow{2}{*}{ \%ile } & \multicolumn{2}{|c|}{ KOLRA } & \multirow{2}{*}{$\begin{array}{l}\text { ORW } \\
\text { (Re) }\end{array}$} & \multirow{2}{*}{ DS } & \multirow{2}{*}{ RTI } & \multirow{2}{*}{ C-10 } & \\
\hline & & & & & & & & & & & & & & & D & (D+PRF) & & & & & \\
\hline 1 & $\mathrm{Si}$ & M & $6 ; 11$ & 92 & A & 79 & 64 & ND & 27 & 80 & 56 & 100 & Under 1st grade & 1 & & & 24.53 & $x$ & O & O & DLD \\
\hline 2 & Do & M & $7 ; 01$ & 109 & A & 79 & 95 & ND & 2 & 80 & 61 & 107 & Under 1st grade & 1 & & & 1.89 & O & 0 & O & \\
\hline 3 & Tae & M & $7 ; 01$ & 101 & A & 93 & 78 & ND & 24 & 80 & 62 & 111 & Under 1st grade & 1 & & & 48.83 & ○ & $\times$ & O & ADHD \\
\hline 4 & Seung & M & $7 ; 09$ & 103 & A & 96 & 75 & RSR & 17 & 80 & 54 & 111 & Under 1st grade & 1 & 15.79 & 4.23 & 39.13 & ○ & 0 & O & ADHD \\
\hline 5 & Jung & M & $8 ; 05$ & 89 & $\mathrm{BA}$ & 59 & 88 & $\mathrm{DR}$ & 19 & 67 & 66 & 101 & Under 1st grade & 3 & 168.42 & 50.59 & 25.49 & $x$ & $\times$ & O & $\begin{array}{l}\text { DLD, } \\
\text { TOT }\end{array}$ \\
\hline 6 & Yu & $\mathrm{F}$ & $8 ; 09$ & 101 & A & 83 & 80 & ND & 80 & 86 & 60 & 81 & Under 1st grade & 10 & 5.00 & 15.00 & 28.89 & O & 0 & O & \\
\hline 7 & Hyun & $\mathrm{F}$ & $10 ; 00$ & 90 & A & 96 & 91 & SR & 46 & 66 & 68 & 103 & Under 1st grade & 1 & 58.69 & 26.32 & 18.96 & ○ & 0 & O & SSD \\
\hline 8 & $\mathrm{Da}$ & $M$ & $10 ; 04$ & 119 & $\mathrm{AA}$ & 83 & 87 & SR & 73 & 79 & 56 & 84 & Under 1st grade & 1 & 45.20 & 31.78 & & O & 0 & O & \\
\hline 9 & Rae & $\mathrm{F}$ & $10 ; 07$ & 92 & A & 81 & 81 & $\mathrm{DR}$ & 41 & 76 & 58 & 98 & Under 1st grade & 1 & & & 11.29 & $\times$ & 0 & O & DLD \\
\hline
\end{tabular}

$A=$ average; $A A=$ above average; $A D H D=$ attention deficit hyperactivity disorders; $B A=$ below average; Com = comorbidity; $C-I Q=I 0$ cutoff approach; $D=$ decoding; $D L D=$ developmental language disorders; $\mathrm{DR}=$ developmental retardation; $\mathrm{DS}=$ The $\mathrm{IQ}$ achievement discrepancy model; $\mathrm{Dys}=$ dyslexia; $\mathrm{E}=$ expressive vocabulary test; $\mathrm{EDR}=$ expressive vocabulary developmental retardation; K-CTONI=Korean Comprehensive Test of Nonverbal Intelligence-2 (Park, 2014); KOLRA=Korean Language-based Reading Assessment (Pae et al., 2015); LC= Listening comprehension; $\mathrm{N}=$ number; $\mathrm{ND}=$ normal development; $\mathrm{P}=$ Participants; PA=Phonological awareness; PRF=Paragraph reading fluency; $\mathrm{R}=$ receptive vocabulary test; $\mathrm{RC}=$ Reading comprehension; $\mathrm{REVT}=$ receptive \& expressive vocabulary test (Kim et al., 2009); RSR= receptive vocabulary slight retardation; $\mathrm{RTI}=$ Response to Intervention; $\mathrm{SR}=$ slight retardation; $\mathrm{SSD}=$ speech sound disorders; Std scores=standardized score; $T 0 T=$ tip of the tongue; Level=level of $(\mathrm{D}+\mathrm{RC}+\mathrm{PRE})$ score; \%ile= \%ile of (D+RC+PRE) level; Progress (\%)=(2nd evaluation score-1st evaluation score)/1st evaluation score.

능을 보였던 $\mathrm{Yu}(8 ; 09, \mathrm{~F})$ 와 $\mathrm{Da}(10 ; 04, \mathrm{M})$ 아동은 80 점과 73 점의 해 독능력을 보였다. 읽기이해(RC) 능력은 괄호가 있는 의미 문장을 읽고 괄호 안에 들어갈 적절한 말을 쓰는 과제로 읽기 이해력과 쓰
기 능력이 모두 요구되는 과제였다. 측정 결과 Hyun $(10 ; 00, \mathrm{~F})$ 과 Jung $(8 ; 05, \mathrm{M})$ 아동은 표준점수 66점과 67점이었고 나머지 8 명 아 동은 79-86점의 유사한 읽기이해 능력을 보이고 있었다. 읽기 유창 
성(PRF)에 대한 평가결과는 9명 대상자 모두가 54-68점의 유사한 읽기 유창성 능력을 보이고 있었다. 그리고 듣기 이해(LC)에 있어서 는 $\operatorname{Si}(6 ; 11, M)$, Do (7;01, M), Tae (7;01, M), Seung (7;09, M), Jung $(8 ; 05, \mathrm{M})$, Hyun $(10 ; 00, \mathrm{~F})$, 그리고 Rae $(10 ; 07, \mathrm{~F})$ 7명 아동은 98-111 점의 유사한 평균수준의 능력을 보였다. 하지만 앞서 다른 아동들 에 비하여 높은, 73-80점대의 유사한, 해독(D) 능력을 보였던 $\mathrm{Yu}$ $(8 ; 09, \mathrm{~F})$ 와 $\mathrm{Da}(10 ; 04, \mathrm{M}) 2$ 명 아동은 듣기 이해(LC)에 있어서는 다 른 대상자들에 비하여 평균 하의 저조한 듣기 이해(LC) 능력을 보 였다(Figure 3).

위에서 살펴본 KOLRA 핵심검사 4가지 과제(해독, 읽기이해, 읽 기 유창성, 듣기이해)에 대한 점수 결과로 9명 대상자를 구분하면 Si $(6 ; 11, M)$, Do (7;01, M), Tae (7;01, M), Seung (7;09, M), 4명 아동 (Group 1 in Figure 4)은 모두 1학년이며, 낮은 해독과 읽기 유창성 에 비하여 읽기이해는 어느 정도 가능하고(평균 하) 듣기 이해력은 평균 또는 평균 하 집단이었다. 그리고 빠른 이름대기 능력이 가장 느리게 나타났는데 이는 $\mathrm{Si}(6 ; 11, \mathrm{M})$ 아동이 느리게 반응한 결과 때
문으로 집단의 특성으로 보기는 어려웠다. Hyun (10;00, F)과 Rae $(10 ; 07, F)$ 명 아동(Group 3 in Figure 4)은 모두 4학년이며, 평균의 비언어성지능으로 1학년 group 1 아동보다는 높은 해독 능력을 보 였지만 읽기이해와 듣기이해 능력이 더 낮은 집단이었다. 그리고 이 외의 읽기관련 변인 능력은 다른 집단과 유사하였다. 이외 $\mathrm{Yu}(8 ; 09$, F)와 Da (10;04, M) 2명 아동(Group 4 in Figure 4)은 학년은 2학년 4 학년으로 다르지만 평균적인 비언어성지능에 다른 나머지 세 집 단보다는 해독 능력은 가장 높았지만 읽기 유창성과 읽기이해는 다 른 집단과 유사하였다. 그리고 듣기 이해력이 유일하게 평균 하로 낮게 나타났다. 마지막으로 Jung $(8 ; 05, \mathrm{M})$ 아동(Group 2 in Figure 4)은 유일하게 평균하의 비언어성지능을 보였고, 해독능력이 가장 낮았으며 듣기 이해력은 평균 수준이었다는 것을 빼고는 거의 모든 읽기관련 능력이 다른 집단에 비하여 저조하여 다른 8 명 난독증 대 상자 아동과는 다른 경향을 보이고 있었다. KOLRA 상세검사 결과 에 있어서는 대상자 모두가 낮은 능력을 보였지만, 음운인식과 쓰 기능력은 학년이 높은 난독증 대상자가 포함된 Group 3과 4가 다

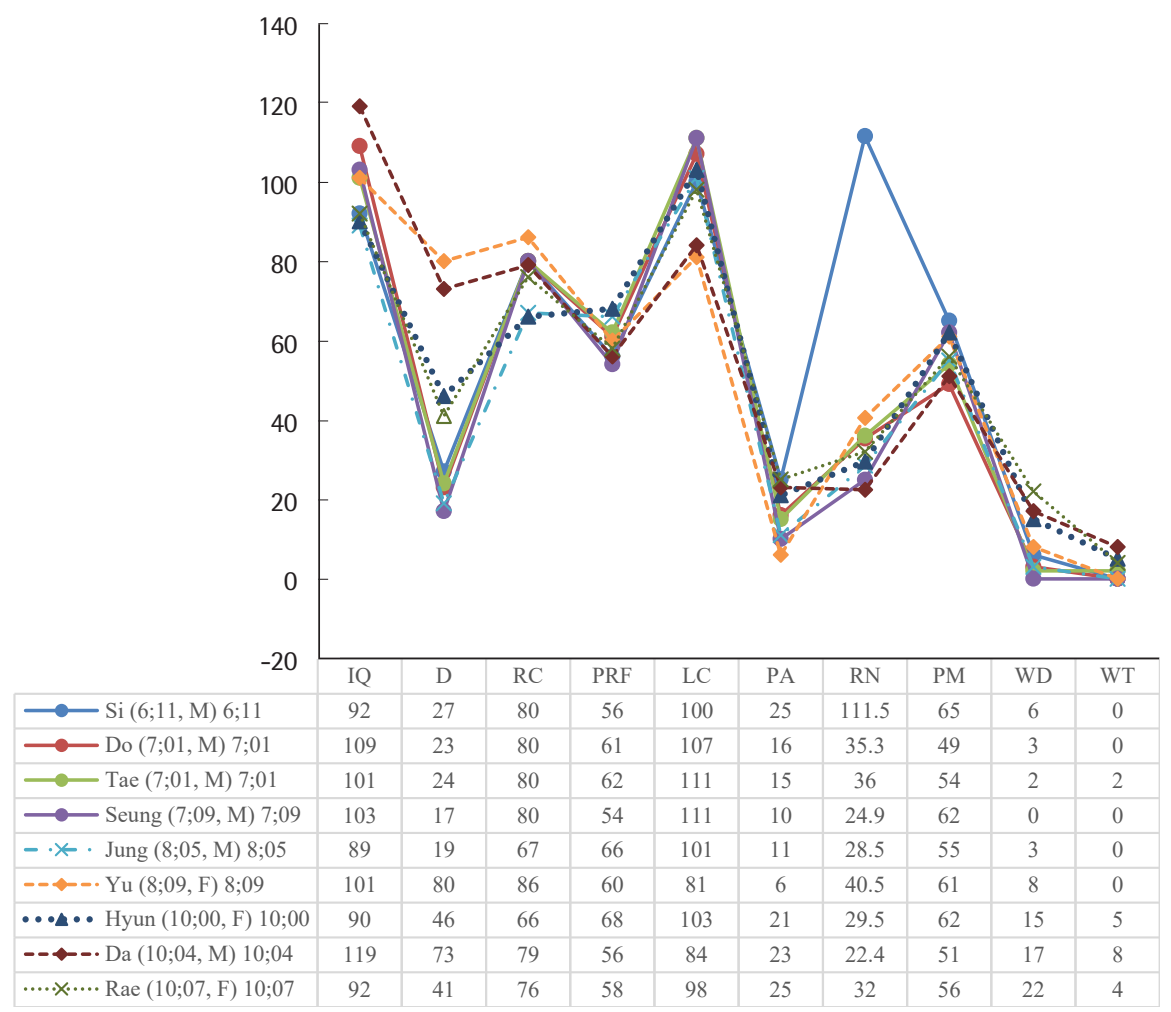

Figure 3. Participants' profiling for KOLRA.

$\mathrm{D}=$ decoding; $\mathrm{F}=$ female; IQ = intelligence quotient; $K O L R A=$ Korean Language-based Reading Assessment (Pae et al., 2015); LC=Listening comprehension; $M=$ male; $\mathrm{PA}=$ Phonological awareness; $\mathrm{PM}=$ phonological memory; $\mathrm{PRF}=$ Paragraph reading fluency; $\mathrm{RC}=$ Reading comprehension; $\mathrm{RN}=$ rapid naming; $\mathrm{WD}=\mathrm{Writing}$ I: Dictation; WT = Writing II: Topic article.

In the KOLRA test results, KOLRA Key assessments (RC, PRF, LC, PA) is the standardized score and KOLRA detailed assessments (RN, PM, WD, WT) is the raw score. And $\mathrm{RN}$ is a score of measuring the number and the time to name the letters, which means that the larger the size, the more time it took. 


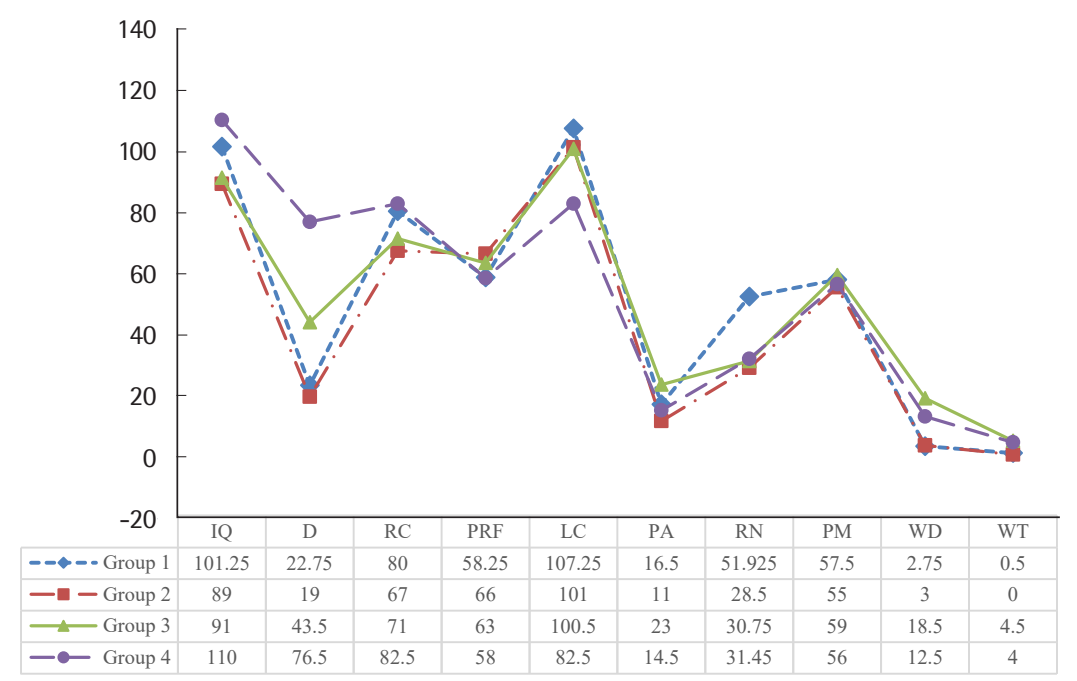

Figure 4. Participants' profiling for KOLRA.

$\mathrm{D}=$ decoding; $\mathrm{F}=$ female; $\mathrm{IQ}=$ intelligence quotient; $\mathrm{KOLRA}=$ Korean Language-based Reading Assessment (Pae et al., 2015); LC=Listening comprehension; $M=$ male; $\mathrm{PA}=$ Phonological awareness; $\mathrm{PM}=$ phonological memory; PRF= Paragraph reading fluency; $\mathrm{RC}=$ Reading comprehension; $\mathrm{RN}=$ rapid naming; $\mathrm{WD}=\mathrm{Writing}$ I: Dictation; WT = Writing II: Topic article.

In the KOLRA test results, KOLRA Key assessments (RC, PRF, LC, PA) is the standardized score and KOLRA detailed assessments (RN, PM, WD, WT) is the raw score. And $\mathrm{RN}$ is a score of measuring the number and the time to name the letters, which means that the larger the size, the more time it took.

른 집단에 비하여는 높게 나타났다(Figure 4).

KOLRA 핵심검사 이외에 상세검사 5 가지는 코드 값 결과에서 표준화 점수는 제시되지 않고 또래와의 비교를 위해 \%ile값이 제시 되었다. 이에 음운인식(phonological awareness, PA), 빠른 이름대 기(rapid naming, RN), 음운기억(phonological memory, PM), 받 아쓰기(writing I: dictation, WD), 주제 글쓰기(writing II: topic, WT) 5 가지 상세검사에 대해 \%ile값을 통해 개별 아동의 특성을 비 교하면 다음과 같다. 첫째, 음절과 음소를 결합하거나 분리하는 음 운인식 $(\mathrm{PA})$ 능력이 9 명 대상자 모두 또래 아동에 비하여 $25 \%$ ile 이 하의 낮은 능력을 보였다. 이중에서도 특히 $\mathrm{Yu}(8 ; 09, \mathrm{~F})$ 아동은 $5 \% \mathrm{ile}$ 이하의 음운인식 능력을 보여 읽기에 큰 어려움을 보이는 것으로 나타났다. 둘째, 숫자와 받침 없는 1음절 낱말을 보고 빠르게 이름 을 대는 빠른 이름대기(RN) 과제에서도 9 명 모든 아동이 $25 \%$ ile 이 하의 능력을 보였다. 그 중에서도 $\mathrm{Si}(6 ; 11, \mathrm{M}), \mathrm{Yu}(8 ; 09, \mathrm{~F}), \operatorname{Rae}(10 ; 07$, F) 3 명 아동은 $5 \%$ ile 이하 그리고 Hyun $(10 ; 00, \mathrm{~F})$ 아동은 5-10\%ile 로 나타나 음운을 빠르게 산출하는 능력 또는 한글을 읽는 능력이 저조한 것으로 나타났다(Table 6). 그리고 Figure 3에서 확인할 수 있듯이, 특히 $\mathrm{Si}(6 ; 11, \mathrm{M})$ 아동이 빠르게 이름대기 원 점수가 111.5 로 가장 높아, 가장 느리게 이름대기를 한 것을 확인할 수 있었다. 셋째, 2 에서 5 음절 비단어를 듣고 따라 말하는 음운기억(PM) 능력 도 모든 아동이 $25 \%$ ile 이하의 저조한 수행력을 보였다. 그 중에서
도 특히 $\mathrm{Da}(10 ; 04, \mathrm{M})$ 아동은 $5 \% \mathrm{ile}$ 이하, $\mathrm{Do}(7 ; 01, \mathrm{M})$ 와 Rae $(10 ; 07$, F) 아동은 5-10\%ile의 저조한 수행을 보였다. 넷째, 낱말과 문장을 듣고 받아쓰는 능력(WD)은 9 명 모든 대상자가 $10 \%$ ile 이하의 능력 을 보였다. 그리고 마지막으로 자신의 장래희망 또는 꿈에 대해 자유 롭게 쓰도록 한 주제 글 쓰기(WT) 과제에 대해서 $\mathrm{Si}(6 ; 11, \mathrm{M})$, Do (7;01, M), Seung (7;09, M), Jung (8;05, M), Yu (8;09, F) 5명 아동은 전혀 쓰지 못하였다. 단지 Tae (7;01, M), Hyun (10;00, F), Da (10;04, $\mathrm{M})$, 그리고 Rae $(10 ; 07, \mathrm{~F}) 4$ 명 아동만이 약간의 내용을 적었을 뿐이 며, 주제 글 쓰기 내용과 형식이 또래 수준에 미치지 못하는 $25 \%$ ile 이하였다.

KOLRA 9 개 소검사를 4 개 핵심검사와 5 개 상세검사 둘로 나누어 구분하여 분석한 결과 4 개 핵심검사에서 유사한 결과 유형을 보인 4집단(1집단[Si (6;11, M), Do (7;01, M), Tae (7;01, M), Seung (7;09, $\mathrm{M})]$, 2집단[Hyun (10;00, F), Rae (10;07, F)], 3집단[Yu (8;09, F), Da $(10 ; 04, \mathrm{M})]$, 4 집단[Jung $(8 ; 05, \mathrm{M})])$ 은 상세검사에서는 유사한 결과 패턴이 나타나지는 않았다. 즉, 해독, 읽기이해, 듣기이해, 읽기 유창 성이 난독증을 진단하는 부분에 있어 핵심검사로 작용하지만 이러 한 핵심검사 결과 나타나는 난독증 대상자 유형 특성이 상세검사 결과에도 유사하게 나타나는 것은 아니었다.

그리고 QRW (Kim, Jai et al., 2020) 읽기능력 원 점수 결과는 아 동 별로 23점부터 62점까지로 차이를 보였다. 현재 QRW는 출판 중 
에 있는 검사도구로 규준안은 확인하지 못하였지만 읽기능력 천정 점인 72점에 모든 아동이 도달하지는 못하였다(Table 6).

난독증 대상자 아동의 어머님과 또는 보호자와의 초기 면담을 통해 대상자의 동반장애 유/무와 과거에 치료를 받았던 부분과 현 재 치료받고 있는 부분에 대해 살펴보았다. 그 결과 $\mathrm{Si}(6 ; 11, \mathrm{M})$ 아 동은 어린 시기 때부터 전반적인 발달이 느려 언어치료와 인지치료 를 현재까지 받고 있음을 확인하였다. 그리고 Tae $(7 ; 01, M)$ 와 Seung $(7 ; 09, \mathrm{M})$ 아동은 $\mathrm{ADHD}$ 증상을 보이고 있으며, 이중 Tae 아동은 현재 $\mathrm{ADHD}$ 약물치료를 병행하고 있음을 확인하였다. 이외에, Hyun $(10 ; 00, \mathrm{~F})$ 아동은 읽기도 유창하지 않지만 발음이 부정확하다는 어머님의 보고에 의해 U-TAP 2 (Kim, Shin et al., 2020)를 추가 평 가하였다. 그 결과 문장 수준에서의 자음 정확도(PCC)가 $80.8 \%$ 였 으며 종성 생략을 주로 보이는 특성에 의해 말 명료도가 낮아 SSD 아동으로 구분하였다. 그리고 초기 어머님과 보호자의 면담을 통 해서는 읽기 문제 이외에는 다른 문제가 없다고 한 나머지 5명 대상 아동 중 Jung $(8 ; 05, \mathrm{M})$ 아동은 수용어휘능력은 약간지체, 표현어휘 능력은 $-2 \mathrm{SD}$ 이하로 나타났다. 그리고 대화에 있어서 적절한 어휘 를 찾아 표현하지 못하고 “그거 있잖아요. 어어...”를 반복하면서 설 단현상을 추가로 보였다. 이에 Jung $(8 ; 05, \mathrm{M})$ 아동은 DLD와 TOT 동반장애 및 증상을 평가 후 추가하였다. Rae $(10 ; 07, \mathrm{~F})$ 아동은 수 용 및 표현어휘능력이 $10 \%$ ile 미만으로 $-2 \mathrm{SD}$ 이하에 속하여 수용 과 표현어휘력 모두 또래 아동과 비교하여 낮은 수준으로 평가되어 $\mathrm{DLD}$ 를 동반하고 있음을 확인하였다(Table 6).

\section{중재 후, 읽기능력 진전도 평가결과}

언어재활 경력 2년 이상의 6 명 언어재활사들에 의해 초기 평가 후 3 개월 간 읽기관련 중재가 진행되었다. 중재의 내용은 언어재활 사들이 매주 금요일마다 회의를 통해 음운인식과 해독부분을 위 주로 진행하는 내용 범위에서 통일하고, 개별 아동의 수준과 특성 에 맞게 재구성하였다.

중재 3개월 후 읽기능력의 향상도를 KOLRA와 QRW를 이용하 여 재평가하도록 하였다. 하지만 COVID 19 여파로 대상자를 대면 할 수 없는 상황이 발생하여 9명 대상자 모두가 두 가지 검사를 모두 수행하지는 못하였다. 이에 읽기능력 재평가결과는 KOLRA의 해독 과 ‘해독+읽기 유창성’ 점수의 진전도[(2차평가 결과 점수-1차평가 결과 점수) $/ 1$ 차평가 결과점수와 $\mathrm{QRW}$ 의 읽기능력 점수의 진전도 를 Excel을 이용하여 계산하고 그 결과를 Table 7에 제시하였다.

읽기능력 진전도 평가 결과 모든 대상자는 중재 후에 읽기 능력 이 향상되었지만 개별 아동에 따라 그리고 평가도구에 따라서 진 전도의 차이가 큰 것으로 나타났다. 먼저 KOLRA의 전/후 평가는 5
명(Seung, Jung, Yu, Hyun, Da)만 진행되었으며 해독(D)과 ‘해독+ 읽기 유창성 $(\mathrm{D}+\mathrm{PRF})$ '으로 구분하여 진전도를 계산하였다. 그 결 과 Seung $(7 ; 09, \mathrm{M})$ 아동은 해독 $15.79 \%$, '해독+유창성' $4.23 \%$ 의 진전도를 보였다. 즉 해독 능력은 향상되었지만 유창성 부분에 있 어서는 아직 그 진전도가 낮아 아직 해독 수준의 읽기중재가 요구 됨을 알 수 있었다. Jung $(8 ; 05, \mathrm{M})$ 은 $168.42 \%$ 와 $50.59 \%$ 의 진전도 를 보여 해독부분에 있어 중재효과가 탁월하였으며 아직 유창하게 읽는 정도는 도달하지 못하였음을 평가를 통해 알 수 있었다. $\mathrm{Yu}$ $(8 ; 09, \mathrm{~F})$ 는 $5.00 \%, 15.00 \%$ 의 진전도를 보여 해독보다는 읽기 유창 성이 더 진전을 보인 것으로 나타났으며 다른 아동에 비해 해독 진전 도가 느린 편으로 보였다. 그리고 Hyun $(10 ; 00, \mathrm{~F})$ 은 $58.69 \%, 26.32 \%$ 의 진전도를 보여 해독의 진전도가 $50 \%$ 이상 증진된 것을 확인하 였다. 마지막으로 $\mathrm{Da}(10 ; 04, \mathrm{M})$ 는 $45.20 \%, 31.78 \%$ 의 진전도를 보였 다. KOLRA의 해독과 ‘해독+유창성’ 모두 $45 \%$ 이상의 진전도를 보 인 아동은 Jung $(8 ; 05, \mathrm{M})$ 뿐이었다.

그리고 $\mathrm{QRW}$ 의 읽기능력 진전도는 8명(Si, Do, Tae, Seung, Jung, $\mathrm{Yu}, \mathrm{Hyun}, \mathrm{Rae})$ 에게 평가되었다. 읽기능력 원점수 진전도는 $\mathrm{Si}(6 ; 11$, M)는 24.53\%, Do (7;01, M) 1.89\%, Tae (7;01, M) 48.83\%, Seung (7;09, M) 39.13\%, Jung (8;05, M) 25.49\%, Yu (8;09, F) 28.89\%, Hyun $(10 ; 00, F) 18.96 \%$, 그리고 Rae $(10 ; 07, \mathrm{~F})$ 는 $11.29 \%$ 로 나타났다. 즉, $\mathrm{QRW}$ 의 읽기능력 진전도가 $45 \%$ 이상으로 나타난 아동은 Tae (7;01, $\mathrm{M})$ 뿐이었다(Table 7).

\section{3 가지 진단모델별 난독증 진단결과와 동반장애(증상)}

3 가지의 진단모델에 따라서 난독증을 진단하는 기준은 차이를 보이며 이에 따라 난독증으로 분류되기도 하고 그렇지 않기도 하였 다. 이에 대해 자세히 살펴보면 다음과 같다. 첫째, 지능-성취 불일 치모형을 적용하여 난독증을 진단한 결과 비언어성지능 환산점수 가 90 이하이며 REVT (Kim et al, 2009) 표현어휘능력이 또래 평균 -2 SD 이하인 Jung $(8 ; 05, \mathrm{M})$ 과 REVT 수용 및 표현어휘능력 모두 가 또래 평균 $-2 \mathrm{SD}$ 이하인 Rae $(10 ; 07, \mathrm{~F})$ 아동 2 명은 난독증 대상 자에서 제외하였다. 이외 $\mathrm{Si}(6 ; 11, \mathrm{M}), \mathrm{Do}(7 ; 01, \mathrm{M})$, Tae $(7 ; 01, \mathrm{M})$, Seung (7;09, M), Yu (8;09, F), Hyun (10;00, F), 그리고 Da (10;04, M) 7명 아동은 불일치모형 난독증 대상자에 포함되었다(Table 8).

둘째, RTI 모델은 읽기 중재 진전도와 읽기성취수준을 함께 평가 하여, 난독증 진단에서 중재의 진전도가 일정 정도 높게 나타난 아 동은 난독관련 특수교육 대상자에서 제외하도록 하는 것이다. 그 리고 이번 연구에서는 KOLRA의 해독과 '해독+유창성' 모두가 $45 \%$ 이상 또는 QRW의 읽기 진전도가 $45 \%$ 이상으로 나타난 대상 자는 RTI 모델 난독증 대상자에서 제외하도록 정의하였다. 이러한 
정의 하에 Tae $(7 ; 01, \mathrm{M})$ 아동은 $\mathrm{QRW}$ 읽기능력 평가결과 $48.83 \%$ 의 진전도를 보여 RTI 모델 난독증 대상에서 제외하였다. 그리고 Jung $(8 ; 05, \mathrm{M})$ 아동은 KOLRA 해독과 '해독+유창성' 환산점수 진 전도가 $168.42 \%, 50.59 \%$ 로 나타나 RTI 모델 난독증 대상자에서 제 외하였다. 이외 Si (6;11, M), Do (7;01, M), Seung (7;09, M), Yu (8;09, F), Hyun (10;00, F), Da (10;04, M), 그리고 Rae (10;07, F) 7명 아동 은 RTI 모델 난독증 대상자에 포함되었다(Table 7).

셋째, 지능절단점 접근법에서는 평균적인 지능의 범위를 $-2 \mathrm{SD}$ 이상으로 정하고 이러한 폭넓은 환산 지능점수대에서 읽기능력이 저조한 대상자들을 난독증으로 정의하고 있다. 이에 이번 연구에 서는 $\operatorname{Si}(6 ; 11, \mathrm{M}), \operatorname{Do}(7 ; 01, \mathrm{M})$, Tae (7;01, M), Seung (7;09, M), Jung (8;05, M), Yu (8;09, F), Hyun (10;00, F), Da (10;04, M), 그리고 Rae $(10 ; 07, \mathrm{~F})$ 명 모든 대상자가 난독증에 포함되었다(Table 8).

대상자의 어머니와 보호자 면담과 초기평가 결과를 토대로 진단 모델 별 난독증 진단여부와는 상관없이 대상자의 동반장애 또는 증상을 확인한 결과 대상자 9명 중 $\mathrm{Do}(7 ; 01, \mathrm{M}), \mathrm{Yu}(8 ; 09, \mathrm{~F})$, 그리 고 $\mathrm{Da}(10 ; 04, \mathrm{M}) 3$ 명은 추가 증상이나 장애가 없는 난독증 증세만 을 보이는 대상자들로 비언어성지능 환산점수가 $109,101,119$ 로 9명 난독증 대상자 중 지능이 높은 편에 속하였다. 그리고 이들을 제외 한 6명에게서는 $\mathrm{DLD}$ 와 $\mathrm{ADHD}, \mathrm{SSD}, \mathrm{TOT}$ 등의 동반장애 및 동반 증상이 있었다. 구체적으로 살펴보면, $\mathrm{Si}(6 ; 11, \mathrm{M})$ 와 Jung $(8 ; 05, \mathrm{M})$, $\operatorname{Rae}(10 ; 07, \mathrm{~F})$ 아동은 DLD를 동반하였는데, 특히 Jung $(8 ; 05, \mathrm{M})$ 아동은 TOT 증상도 함께 보였다. DLD를 동반하는 아동 중 언어

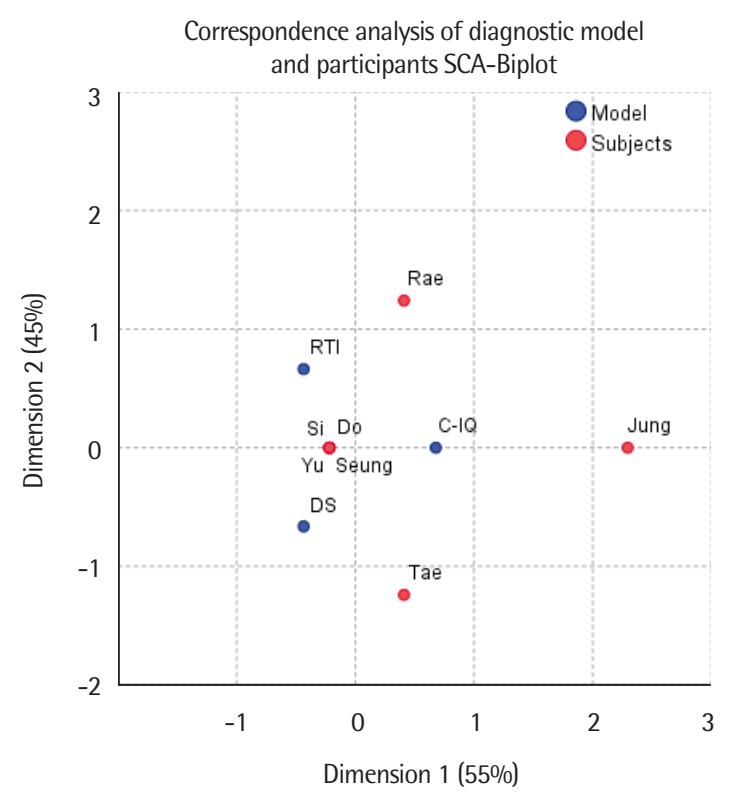

Figure 5. Perceptual mapping of diagnostic model and participants.
치료를 오랫동안 병행한 $\mathrm{Si}(6 ; 11, \mathrm{M})$ 아동을 제외한 Jung $(8 ; 05, \mathrm{M})$ 과 Rae $(10 ; 07, \mathrm{~F})$ 아동은 KOLRA의 읽기이해(RC) 점수가 9 명 대상 자 중 낮은 편에 속하였다.

그리고 Tae (7;01, M)와 Seung $(7 ; 09, \mathrm{M}) 2$ 명 아동은 ADHD 증상 을 동반하고 있음을 어머님 보고에 의해 확인하였다. 이들 $\mathrm{ADHD}$ 동반 아동들의 KOLRA 듣기이해(LC) 능력 환산점수는 111점, 백 분위가 77\%ile로 나타나 다른 대상자와 비교하였을 때 높은 편에 속하였다. 마지막으로 Hyun $(10 ; 00, \mathrm{~F})$ 은 발화 시 종성탈락을 자주 보여 말 명료도가 낮은 SSD 증상을 동반하고 있음을 조음·음운평 가(U-TAP 2)를 통해 확인하였다.

\section{진단모델에 따른 난독증 진단과 동반장애(증상)의 연관성 진단모델과 난독증 진단 단순상응분석(SCA) 결과}

Figure 5의 진단모델 열 점(column points)과 난독증 대상자 행 점(row points) 그래프를 보면 두 요인간의 관계에 있어, $\mathrm{Si}(6 ; 11, \mathrm{M})$, Do $(7 ; 01, \mathrm{M})$, Seung $(7 ; 09, \mathrm{M})$, 그리고 $\mathrm{Yu}(8 ; 09, \mathrm{~F})$ 아동은 세 가지 진단모델 모두와의 거리가 유사하여 진단모델에 따라 난독증 진단 에 영향을 받지 않는 집단임을 알 수 있다. 하지만 Tae $(7 ; 01, \mathrm{M})$, Jung $(8 ; 05, \mathrm{M}), \operatorname{Rae}(10 ; 07, \mathrm{~F})$ 세 아동은 적용된 진단모델에 따라 난독증 대상자가 될 수도 아닐 수도 있음을 확인하였다(Figure 5 \& Table 9).

Table 9. Interpreting the dimension and their correspondence to diagnostic models and participants

\begin{tabular}{|c|c|c|c|c|c|c|c|}
\hline \multirow[t]{2}{*}{ Object } & \multicolumn{2}{|c|}{ Coordinates } & \multicolumn{2}{|c|}{$\begin{array}{l}\text { Contribution to } \\
\text { inertia }\end{array}$} & \multicolumn{3}{|c|}{$\begin{array}{c}\text { Explanation by } \\
\text { dimension }\end{array}$} \\
\hline & I & $\|$ & 1 & $\|$ & 1 & $\|$ & Total \\
\hline \multicolumn{8}{|c|}{ Diagnostic models } \\
\hline DS & -.436 & -.663 & 1.96 & .500 & .324 & .676 & 1.000 \\
\hline RTI & -.436 & .663 & 1.96 & .500 & .324 & .676 & 1.000 \\
\hline C-10 & .678 & .000 & 6.09 & .000 & 1.000 & .000 & 1.000 \\
\hline \multicolumn{8}{|c|}{ Participants } \\
\hline Si & -.219 & .000 & .021 & .000 & 1.000 & .000 & 1.000 \\
\hline Do & -.219 & .000 & .021 & .000 & 1.000 & .000 & 1.000 \\
\hline Tae & .410 & -1.240 & .049 & .500 & .108 & .892 & 1.000 \\
\hline Seung & -.219 & .000 & .021 & .000 & 1.000 & .000 & 1.000 \\
\hline Jung & 2.294 & .000 & .775 & .000 & 1.000 & .000 & 1.000 \\
\hline Yu & -.219 & .000 & .021 & .000 & 1.000 & .000 & 1.000 \\
\hline Hyun & -.219 & .000 & .021 & .000 & 1.000 & .000 & 1.000 \\
\hline $\mathrm{Da}$ & -.219 & .000 & .021 & .000 & 1.000 & .000 & 1.000 \\
\hline Rae & .410 & 1.240 & .049 & .500 & .108 & .892 & 1.000 \\
\hline
\end{tabular}

Contribution to inertia = proportion of dimension's inertia attributable to each category; Explanation by dimension= proportion of category variation accounted by dimension; DS= The IQ achievement discrepancy model; RTI=Response to Intervention; $\mathrm{C}-\mathrm{IQ}=1 \mathrm{O}$ cutoff approach. 


\section{동반장애(증상)와 난독증 단순상응분석(SCA) 결과}

동반장애(증상) 열 점과 난독증 대상자 행 점 그래프 Figure 5 를 보면 두 요인 간의 관계에 있어, $\mathrm{Si}(6 ; 11, \mathrm{M})$, Jung $(8 ; 05, \mathrm{M})$, Rae (10;07,

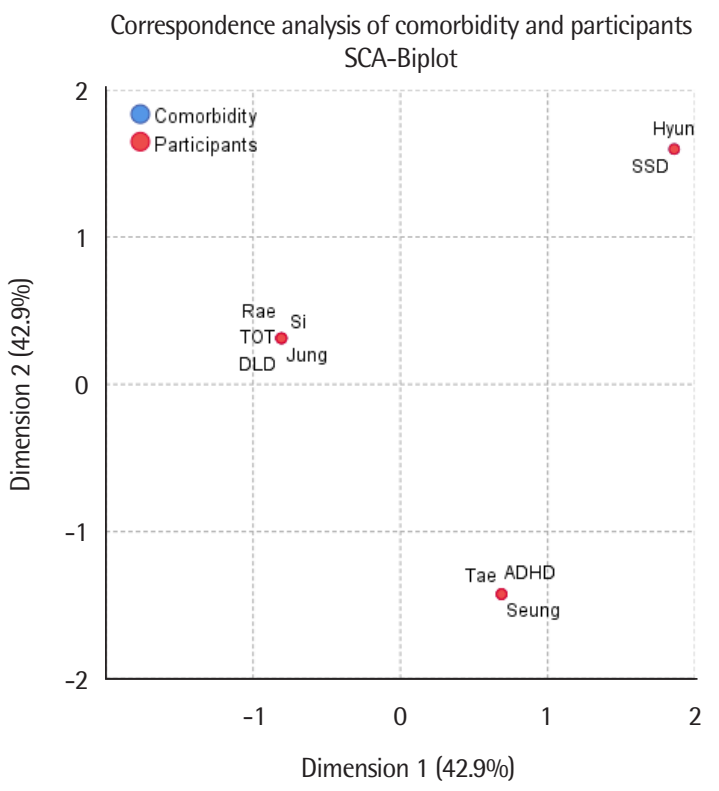

Figure 6. Perceptual mapping of comorbidity and participants.

Table 10. Interpreting the dimension and their correspondence to comorbidity and participants

\begin{tabular}{|c|c|c|c|c|c|c|c|}
\hline \multirow[t]{2}{*}{ Object } & \multicolumn{2}{|c|}{ Coordinates } & \multicolumn{2}{|c|}{$\begin{array}{l}\text { Contribution to } \\
\text { inertia }\end{array}$} & \multicolumn{3}{|c|}{$\begin{array}{c}\text { Explanation by } \\
\text { dimension }\end{array}$} \\
\hline & 1 & $\|$ & 1 & $\|$ & I & $\|$ & Total \\
\hline \multicolumn{8}{|c|}{ Comorbidity } \\
\hline DLD & -.807 & .313 & .279 & .042 & .690 & .104 & .794 \\
\hline ADHD & .686 & -1.425 & .134 & .580 & .188 & .812 & 1.000 \\
\hline TOT & -.807 & .313 & .093 & .014 & .261 & .039 & .300 \\
\hline SSD & 1.858 & 1.597 & .493 & .364 & .575 & .425 & 1.000 \\
\hline \multicolumn{8}{|c|}{ Participants } \\
\hline $\mathrm{Si}$ & -.807 & .313 & .093 & .014 & .489 & .074 & .563 \\
\hline Do & - & - & - & - & - & - & - \\
\hline Tae & .686 & -1.425 & .067 & .290 & .188 & .812 & 1.000 \\
\hline Seung & .686 & -1.425 & .067 & .290 & .188 & .812 & 1.000 \\
\hline Jung & -.807 & .313 & .186 & .028 & .489 & .074 & .563 \\
\hline Yu & - & - & - & - & - & - & - \\
\hline Hyun & 1.858 & 1.597 & .493 & .364 & .575 & .425 & 1.000 \\
\hline $\mathrm{Da}$ & - & - & - & - & - & - & - \\
\hline Rae & -.807 & .313 & .093 & .014 & .489 & .074 & .563 \\
\hline
\end{tabular}

Contribution to inertia = proportion of dimension's inertia attributable to each category; Explanation by dimension = proportion of category variation accounted by dimension; $\mathrm{DLD}=$ developmental language disorders; $\mathrm{ADHD}=$ attention deficit hyperactivity disorders; TOT = tip of the tongue; SSD= speech sound disorders.

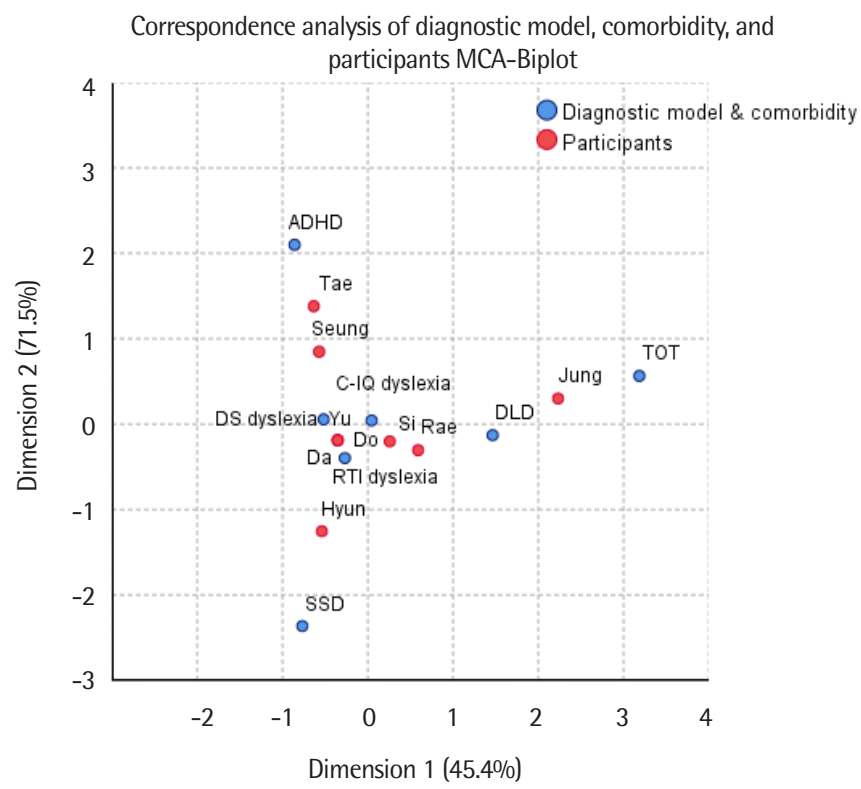

Figure 7. Perceptual mapping of diagnostic model, comorbidity, and participants.

Table 11. Interpreting the dimension and their correspondence to diagnostic models, comorbidity, and participants

\begin{tabular}{|c|c|c|c|c|c|c|c|}
\hline \multirow[t]{2}{*}{ Object } & \multicolumn{2}{|c|}{ Coordinates } & \multicolumn{2}{|c|}{$\begin{array}{l}\text { Contribution to } \\
\text { inertia }\end{array}$} & \multicolumn{3}{|c|}{$\begin{array}{l}\text { Explanation by } \\
\text { dimension }\end{array}$} \\
\hline & 1 & $\|$ & 1 & $\|$ & 1 & $\|$ & Total \\
\hline \multicolumn{8}{|c|}{ Diagnostic models } \\
\hline DS & -.517 & .056 & .089 & .001 & .681 & .006 & .687 \\
\hline RTI & -.268 & -.398 & .024 & .070 & .183 & .305 & .488 \\
\hline$C-10$ & .045 & .042 & .001 & .001 & .076 & .052 & .128 \\
\hline \multicolumn{8}{|c|}{ Comorbidity } \\
\hline DLD & 1.465 & -.130 & .306 & .003 & .732 & .004 & .736 \\
\hline $\mathrm{ADHD}$ & -.858 & 2.100 & .070 & .554 & .153 & .693 & .846 \\
\hline ТОТ & 3.184 & .565 & .482 & .020 & .790 & .019 & .808 \\
\hline SSD & -.767 & -2.364 & .028 & .351 & .063 & .456 & .520 \\
\hline \multicolumn{8}{|c|}{ Participants } \\
\hline $\mathrm{Si}$ & .258 & -.202 & .013 & .010 & .127 & .059 & .186 \\
\hline Do & -.352 & -.188 & .018 & .007 & .269 & .058 & .328 \\
\hline Tae & -.633 & 1.381 & .057 & .359 & .185 & .668 & .854 \\
\hline Seung & -.570 & .848 & .062 & .181 & .334 & .560 & .894 \\
\hline Jung & 2.232 & .300 & .711 & .017 & .915 & .013 & .928 \\
\hline Yu & -.352 & -.188 & .018 & .007 & .269 & .058 & .328 \\
\hline Hyun & -.538 & -1.255 & .055 & .395 & .125 & .516 & .641 \\
\hline $\mathrm{Da}$ & -.352 & -188 & .018 & .007 & .269 & .058 & .328 \\
\hline Rae & .590 & -.305 & .050 & .018 & .255 & .052 & .307 \\
\hline
\end{tabular}

Contribution to inertia = proportion of dimension's inertia attributable to each category; Explanation by dimension = proportion of category variation accounted by dimension; DS=The IQ achievement discrepancy model; RTI=Response to Intervention; $\mathrm{C}-\mathrm{IO}=10$ cutoff approach; $\mathrm{DLD}=$ developmental language disorders; $\mathrm{ADHD}=$ attention deficit hyperactivity disorders; TOT = tip of the tongue; SSD= speech sound disorders. 
$\mathrm{F})$ 아동은 $\mathrm{DLD}$ 를 동반하고 있는 관계성이 있으며, Tae $(7 ; 01, \mathrm{M})$ 와 Seung $(7 ; 09, \mathrm{M})$ 아동은 $\mathrm{ADHD}$ 와 난독증을 동반하는 관계성을 보 이고 있었다. 그리고 Hyun $(10 ; 00, \mathrm{~F})$ 아동은 SSD와 난독증을 동반 하고 있음을 확인할 수 있었다(Figure 6 \& Table 10).

\section{진단모델과 동반장애(증상) 난독증 연관성 다중상응분석(MCA) 결과}

진단모델, 동반장애(증상)에 대한 열 점과 난독증 대상자 행 점 그래프 Figure 6을 보면 세 요인간의 관계에 있어, Si $(6 ; 11, \mathrm{M})$, Do (7;01, M), Yu (8;09, F), Hyun (10;00, F), Da (10;04, M), Rae (10;07, F) 6명 아동은 진단모델과 동반장애(증상)와의 관련성에 있어 유 사한 집단임을 알 수 있었다. 이외 Tae $(7 ; 01, \mathrm{M})$ 와 Seung $(7 ; 09, \mathrm{M})$ 아동은 $\mathrm{ADHD}$ 를 동반하고 있으며 불일치모델(DS dyslexia), 지능 절단점 접근법(C-IQ dyslexia)에 의해 난독증 진단이 가능하다는 공통된 특성을 보이고 있었다. 그리고 Jung $(8 ; 05, \mathrm{M})$ 은 DLD와 TOT 동반증상을 보이는 대상자로 따로 구분되어 있음을 확인할 수 있었다(Figure 7 \& Table 11).

\section{상응분석 분류 집단 별, 읽기관련변인 측정 프로파일 분석결과}

진단모델, 동반장애(증상)에 대한 연관성에 대한 상응분석 결과
3 개의 집단으로 분류 가능하였다. 첫째, $\mathrm{Si}(6 ; 11, \mathrm{M}), \mathrm{Do}(7 ; 01, \mathrm{M})$, Yu $(8 ; 09$, F), Hyun (10;00, F), Da (10;04, M), Rae (10;07, F) 6명 아 동은 세가지 진단모델 모두에서 난독증으로 진단이 가능하였으며 동반장애 없는 난독증 대상자와 $\mathrm{DLD}$ 또는 $\mathrm{SSD}$ 를 동반하는 난독 증 대상 아동을 포함하는 집단이었다. 둘째, Tae $(7 ; 01, \mathrm{M})$ 와 Seung $(7 ; 09, \mathrm{M})$ 아동은 불일치모델(DS dyslexia)과 지능절단점 접근법 (C-IQ dyslexia)에 의해 난독증 진단이 가능하였으며, $\mathrm{ADHD}$ 를 동 반하고 있다는 공통된 특성을 보이고 있었다. 그리고 마지막으로 $\operatorname{Jung}(8 ; 05, \mathrm{M})$ 아동은 지능절단점 접근법 모델을 적용하였을 때만 난독증으로 진단이 가능하였으며, $\mathrm{DLD}$ 와 TOT 동반증상을 보이 는 대상자로 따로 구분되어 있었다(Figure 8).

진단모델과 동반장애(증상)와의 연관성 상응분석 결과로 나누 어진 세 집단(DLD, SSD 동반 또는 일반 난독증 집단, $\mathrm{ADHD}$ 동반 난독증 집단, $\mathrm{DLD}$ 와 TOT를 동반한 아동) 별 읽기관련 변인(음운 \& 인지처리, 음운기억, 언어능력[어휘능력, 듣기/읽기이해, 쓰기]) 프로파일을 분석하여 그 차이를 살펴보면 다음과 같다(Figures 8, $9,10,11)$.

첫째, $\mathrm{DLD}, \mathrm{SSD}$ 동반 또는 일반 난독증 집단은 지능에 있어서는 $\mathrm{ADHD}$ 동반 난독증 아동과 유사하고, $\mathrm{DLD}$ 와 TOT 동반 난독증 아동보다는 높은 평균적인 지능을 나타내고 있었다. 둘째, 수용어

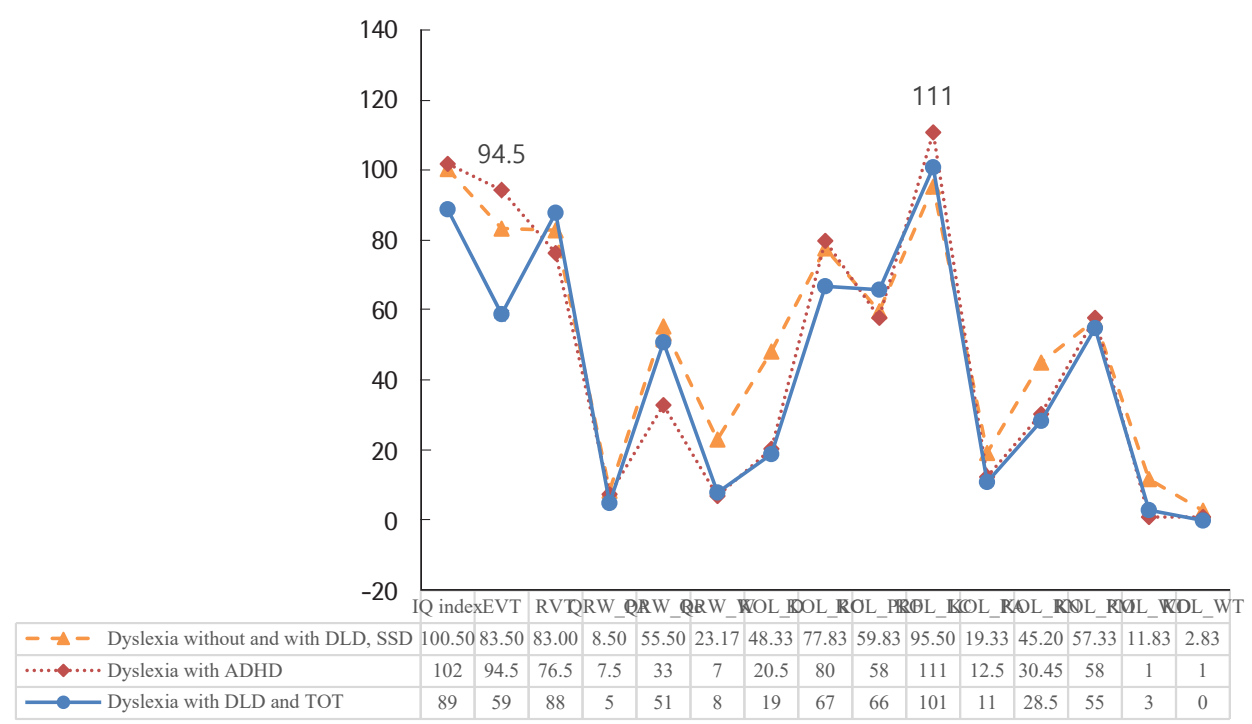

Figure 8. Profiling for three dyslexic groups.

$\mathrm{ADHD}=$ attention deficit hyperactivity disorders; $\mathrm{DLD}=$ developmental language disorders; $\mathrm{EVT}=$ expressive vocabulary test; $\mathrm{F}=\mathrm{female}$; $\mathrm{KOL}=\mathrm{Korean} \mathrm{Language}-$ based Reading Assessment (Pae et al., 2015); LC=Listening comprehension; $\mathrm{M}=$ male; PA=Phonological awareness; PM= phonological memory; PRF=Paragraph reading fluency; $\mathrm{RVT}=$ receptive vocabulary test; $\mathrm{RC}=$ Reading comprehension; $\mathrm{Re}=$ reading; $\mathrm{RC}=$ Reading comprehension; $\mathrm{RN}=$ rapid naming; $\mathrm{QRW}=\mathrm{Quick} \mathrm{Assess-}$ ment of Childhood Reading and Writing (Kim Jai et al., 2020); W= writing; WD=Writing I: Dictation; WT=Writing II: Topic article.

The results of the QRW test is a raw score. In the KOLRA test results, KOLRA Key assessments (RC, PRF, LC, PA) is the standardized score and KOLRA detailed assessments (RN, PM, WD, WT) is the raw score. And KOL_RN is a score of measuring the number and the time to name the letters, which means that the larger the size, the more time it took. 


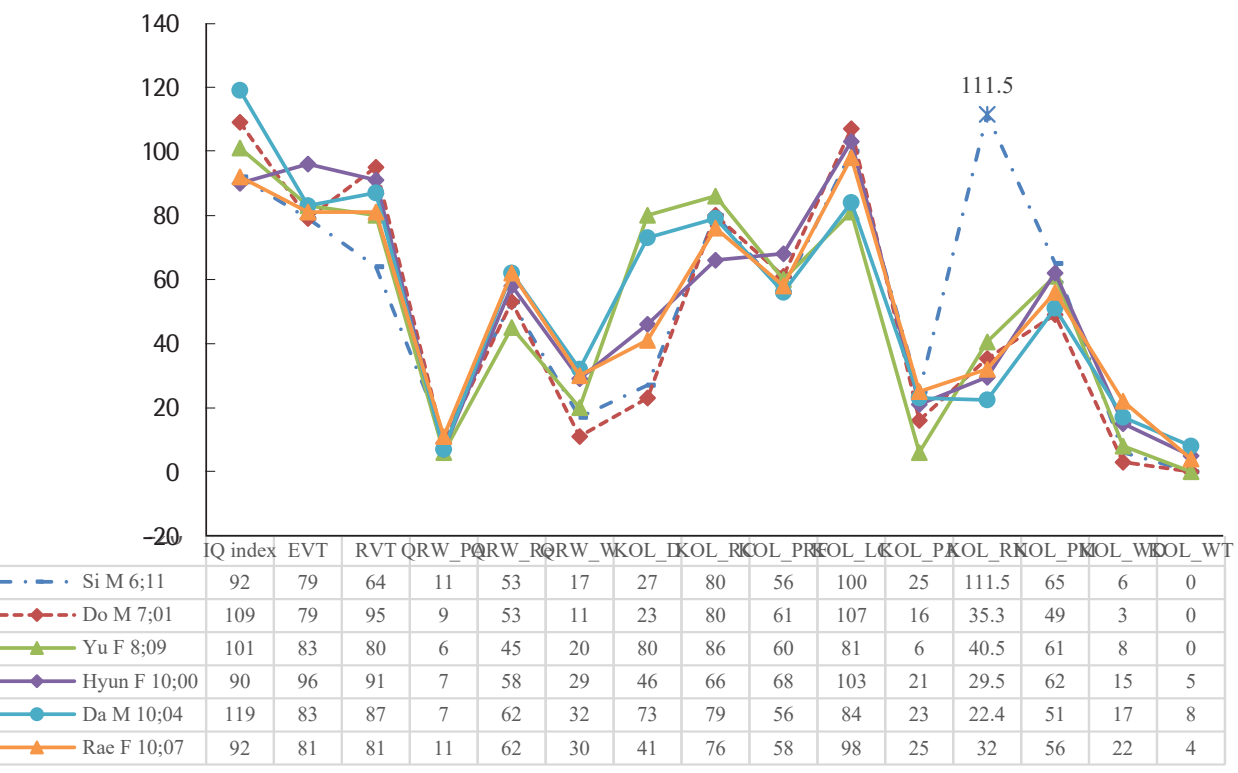

Figure 9. Profiling of dyslexia with or without DLD, SSD.

$\mathrm{ADHD}=$ attention deficit hyperactivity disorders; $\mathrm{DLD}=$ developmental language disorders; $\mathrm{EVT}=$ expressive vocabulary test; $\mathrm{F}=\mathrm{female;} \mathrm{KOL}=\mathrm{Korean} \mathrm{Language}-$ based Reading Assessment (Pae et al., 2015); LC=Listening comprehension; $M=$ male; PA=Phonological awareness; PM= phonological memory; PRF=Paragraph reading fluency; $\mathrm{RVT}=$ receptive vocabulary test; $\mathrm{RC}=$ Reading comprehension; $\mathrm{Re}=$ reading; $\mathrm{RC}=$ Reading comprehension; $\mathrm{RN}=$ rapid naming; $\mathrm{QRW}=\mathrm{Quick} \mathrm{Assess-}$ ment of Childhood Reading and Writing (Kim, Jai et al., 2020); W= writing; WD=Writing l: Dictation; WT=Writing II: Topic article.

The results of the QRW test is a raw score. In the KOLRA test results, KOLRA Key assessments (RC, PRF, LC, PA) is the standardized score and KOLRA detailed assessments (RN, PM, WD, WT) is the raw score. And KOL_RN is a score of measuring the number and the time to name the letters, which means that the larger the size, the more time it took.

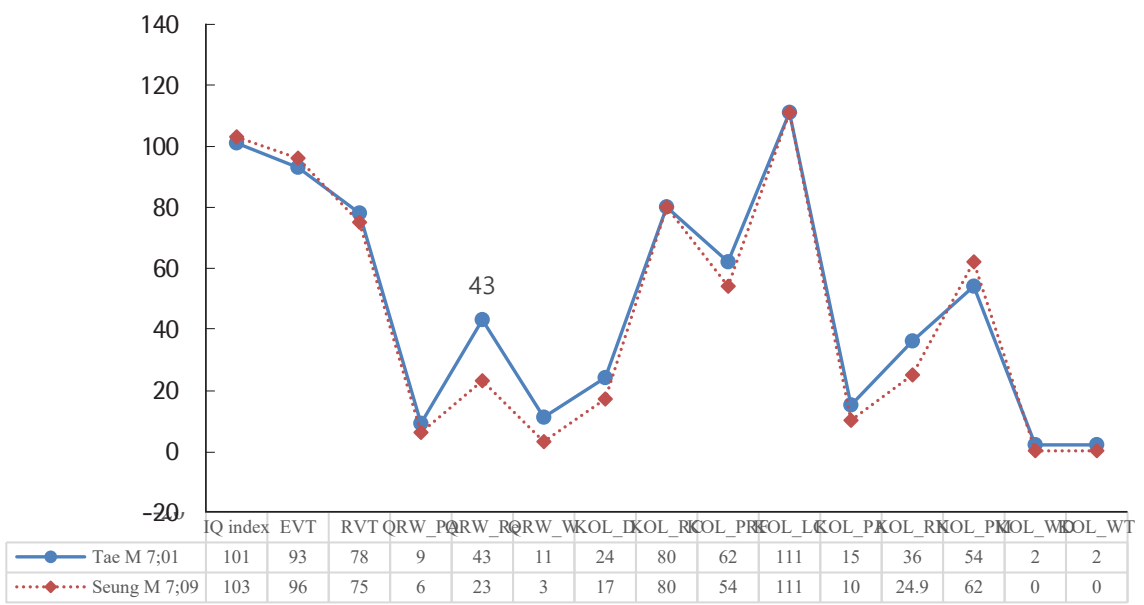

Figure 10. Profiling of dyslexia with ADHD.

$\mathrm{ADHD}=$ attention deficit hyperactivity disorders; $\mathrm{DLD}=$ developmental language disorders; $\mathrm{EVT}=$ expressive vocabulary test; $\mathrm{F}=\mathrm{female;} \mathrm{KOL}=\mathrm{Korean} \mathrm{Language}-$ based Reading Assessment (Pae et al., 2015); LC=Listening comprehension; $M=$ male; PA=Phonological awareness; PM= phonological memory; PRF=Paragraph reading fluency; $\mathrm{RVT}=$ receptive vocabulary test; $\mathrm{RC}=$ Reading comprehension; $\mathrm{Re}=$ reading; $\mathrm{RC}=$ Reading comprehension; $\mathrm{RN}=$ rapid naming; $\mathrm{QRW}=\mathrm{Quick} \mathrm{Assess-}$ ment of Childhood Reading and Writing (Kim, Jai et al., 2020); W= writing; WD=Writing I: Dictation; WT=Writing II: Topic article.

The results of the QRW test is a raw score. In the KOLRA test results, KOLRA Key assessments (RC, PRF, LC, PA) is the standardized score and KOLRA detailed assessments (RN, PM, WD, WT) is the raw score. And KOL_RN is a score of measuring the number and the time to name the letters, which means that the larger the size, the more time it took. 


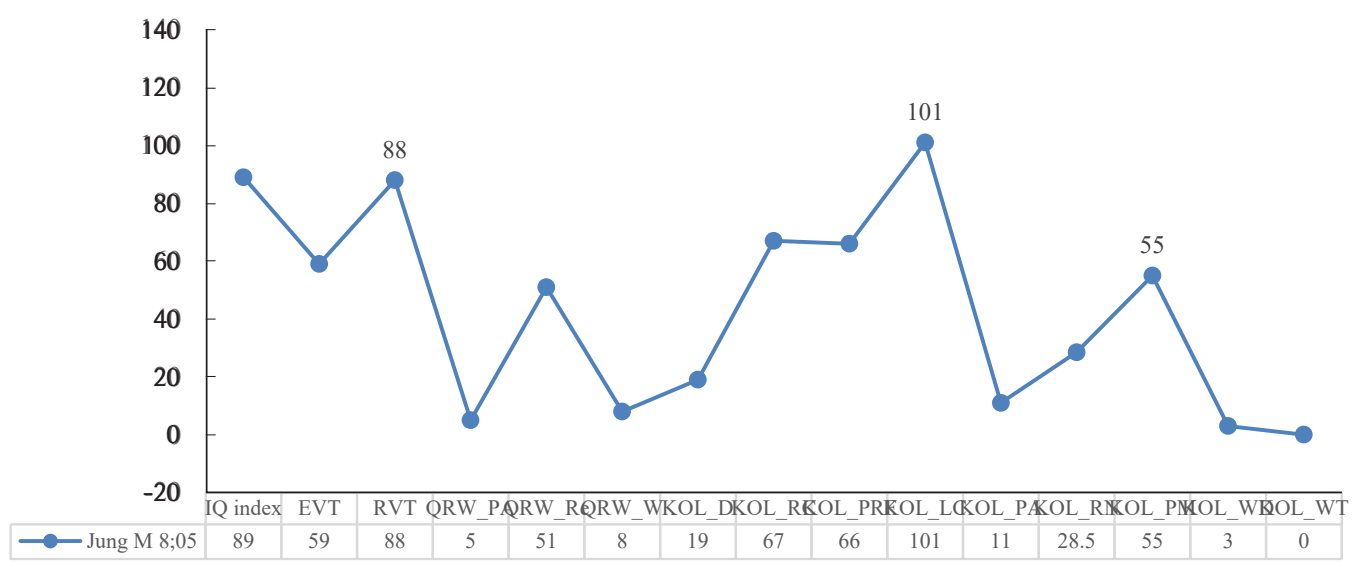

Figure 11. Profiling of dyslexia with DLD \& TOT.

$\mathrm{ADHD}=$ attention deficit hyperactivity disorders; $\mathrm{DLD}=$ developmental language disorders; $\mathrm{EVT}=$ expressive vocabulary test; $\mathrm{F}=\mathrm{female}$; $\mathrm{KOL}=\mathrm{Korean} \mathrm{Language}-$ based Reading Assessment (Pae eet al., 2015); LC=Listening comprehension; $\mathrm{M}=$ male; $\mathrm{PA}=$ Phonological awareness; $\mathrm{PM}=$ phonological memory; PRF=Paragraph reading fluency; $\mathrm{RVT}=$ receptive vocabulary test; $\mathrm{RC}=$ Reading comprehension; $\mathrm{Re}=$ reading; $\mathrm{RC}=$ Reading comprehension; $\mathrm{RN}=$ rapid naming; $\mathrm{QRW}=\mathrm{Quick} \mathrm{Assess-}$ ment of Childhood Reading and Writing(Kim, Jai et al., 2020); W= writing; WD=Writing I: Dictation; WT = Writing II: Topic article.

The results of the QRW test is a raw score. In the KOLRA test results, KOLRA Key assessments (RC, PRF, LC, PA) is the standardized score and KOLRA detailed assessments (RN, PM, WD, WT) is the raw score. And KOL_RN is a score of measuring the number and the time to name the letters, which means that the larger the size, the more time it took.

휘능력은 $\mathrm{ADHD}$ 동반 난독증 집단이 세 집단 중 제일 낮았으며, 표 현어휘능력은 $\mathrm{DLD}$ 와 TOT 동반 난독증 아동이 가장 낮은 점수였 으며, 다른 집단에 비하여 그 차이가 크게 나타날 정도로 지체된(-2 $\mathrm{SD}$ 이상) 것으로 나타났다(Table 10). 셋째, 음운인식 능력(QRW_ $\left.\mathrm{PA}, \mathrm{KOL} \_\mathrm{PA}\right)$ 은 세 집단 모두 저조하였으며, DLD와 TOT를 동반 한 난독증 아동이 가장 저조한 수행력을 보이고 있었다. 넷째, 단어 와 문장 읽기능력(QRW-Re)은 $\mathrm{ADHD}$ 동반 난독증 아동이 나머지 집단에 비하여 특히 저조한 능력을 보였다(Figure 10). 음운인식능 력이 유사하게 낮은 특성을 보이는 세 집단이 읽기에 있어 이러한 차이가 나타난 것은 $\mathrm{ADHD}$ 동반증상이 영향을 미쳤을 것으로 보 인다. 다섯째, 단어와 문장 받아쓰기 능력(QRW_W, KOL_WD)과 주제 글 쓰기능력(KOL_WT)에 있어서는 DLD, SSD 동반 난독증 포함 집단은 단어쓰기 정도는 가능하였다. 하지만, $\mathrm{ADHD}$ 동반 난 독증 집단과 DLD \& TOT 동반 아동은 단어 받아쓰기도 어려웠으 며, 쓰기 능력 점수가 매우 낮았다(Figure 10,11).

여섯째, 2 음절 의미 낱말과 무의미 낱말에 대한 해독(KOL_D) 능력을 측정한 결과 $\mathrm{DLD}, \mathrm{SSD}$ 동반 난독증 포함 집단은 48.33 점이 었으나, $\mathrm{ADHD}$ 동반 난독증 집단과 DLD \& TOT 동반 아동은 20.5, 19 점으로, $\mathrm{DLD}, \mathrm{SSD}$ 동반 난독증 포함 집단에 비하여 2 배 이상의 저조한 수행 력을 보였다. 문단 글 읽기 유창성(KOL_PRE)은 세 집 단 모두 정상적인 수행수준 평균 90점보다 낮게 나타났으며, 유사 하게 저조한 수행력을 보였다. 일곱째, 듣기 이해력(KOL_LC)은 세 집단 모두 평균 90 점 이상으로 또래와 유사한 수준을 보였으며, 세
집단간 비교하였을 때는 $\mathrm{ADHD}$ 동반 난독증 집단이 가장 높은 점 수를 받은 것으로 나타났다(Figure 10).

여덟째, 숫자 및 받침 없는 2 음절 글자 이름을 빨리 말하는 빠른 이름대기(KOL_RN) 능력은 숫자와 글자를 읽은 시간을 측정한 것 으로 결과 점수가 높을수록 더 많은 시간이 소요된 것이다. 측정결 과 $\mathrm{DLD}, \mathrm{SSD}$ 동반 난독증 포함 집단이 세 집단 중에서 가장 이름 을 대는 시간이 오래 걸리는 것으로 나타났으며, 나머지 두 집단은 유사한 빠르기를 보였다(Figure 8). 하지만 이러한 결과는 Figure 8 에서 $\mathrm{DLD}, \mathrm{SSD}$ 동반 난독증 포함 집단 6명 아동만을 따로 구분하 여 프로파일 분석한 결과 $\mathrm{Si}(6 ; 11, \mathrm{M})$ 아동이 다른 아동에 비하여 2 내지 3 배정도 느리게 읽은 결과가 작용한 것으로 확인되었다. 그러 므로 $\mathrm{Si}(6 ; 11, \mathrm{M})$ 아동을 제외한 8 명 난독증 아동의 빠른 이름대기 능력은 모두 유사하게 저조하여 난독증 3집단의 차이보다는 개별 아동의 문제로 볼수 있다(Figure 9).

아홉째, 2-5음절 비단어를 듣고 기억해서 말하는 음운기억 능력 (KOL_PM)은 세 집단 모두 유사하게 저조한 것으로 나타났다(Figure 9).

\section{논의 및 결론}

본 연구는 6 개월 이상의 읽기 정규 초등학교 교육과정을 이수하 였는데도 불구하고, 읽기 능력이 또래에 비하여 저조한 대상자들 중 ‘난독증이 의심되는 초등학생 9명을 어떻게 진단하고 평가해야 
하는가?'라는 질문을 통해 연구가 진행되었다.

언어재활사가 말과 언어문제 대상자를 정확하게 평가하기 위해 서는 대상자의 주요 언어문제가 무엇인지를 이해하고 주요 언어문 제와 관련된 평가도구를 활용하여 평가를 진행하고 그 결과를 분 석해야 한다. 그리고 아동의 문제를 오랫동안 지켜봐 온 주양육자 나 보호자가 알고 있는 대상자 정보를 확인하여 평가 이외의 요인 도 살펴보아야 한다. 이러한 일반적인 언어재활 대상자 평가방식은 대상자의 언어재활 목표와 활동을 정하는데 활용되고 있다. 하지 만 심리학과 교육학, 특수교육학 분야에서 먼저 연구가 진행된 난 독증은 기존의 언어재활 접근법과는 다른 방식의 진단과 치료가 진행되었다(Yoo et al., 2016; Kim et al., 2017; Kim, Kim, Kim, \& Ahn, 2018). 즉, 난독증은 학령기 이후에 문자 읽기학습을 진행하 면서 나타나는 문제를 통해 알 수 있으므로 치료가 아닌 교육적 측 면에서 어떠한 교육을 통해 읽기를 가능하게 할 것인가라는 목적 을 가지고, 치료지원자를 선정하기 위해 진단을 하고 진단 결과에 따라 학교에서 읽기지원 프로그램을 진행하는 방식이었다(Kim \& Koh, 2014).

그러므로 난독증은 언어재활에서 말과 언어평가를 통해 진단과 평가를 하는 방식이 아닌, 난독증 진단모델을 적용하여 난독증을 진단하여 난독 대상자를 구분하는 방식이 적용되어 왔다(Kim \& Koh, 2014; Yoo et al., 2016; Kim et al., 2017, 2018). 이에 난독증 진 단모델(지능-성취 불일치모형, RTI 모델, 지능절단점 접근법)과 DSM-5 (APA, 2013)의 난독증 선별절차와 배제요인으로 난독증을 진단하는 것은 언어재활사에게는 치료지원자를 선정하는 기준 또 는 연구대상자를 선정하기 위한 정보일 뿐이다. 언어재활적 접근법 에서 보면 난독증 대상자를 선정하는 것보다는 난독증 대상자의 말과 언어는 어떠한 특성을 보이며 이러한 특성에 맞는 개별아동 언어재활 목표와 활동은 어떠한 측면에서 어떻게 구성할 지가 주 요 관심사이다.

하지만 언어재활사의 관심과는 달리 현재까지는 난독증을 언어 재활 대상자로 생각하기 보다는 더 많은 학습지원이 요구되는 아동 으로 분류해 지원이 이루어져 왔다(Jung, 2018; Lee, 2019; Lee \& Yang, 2018; Son, Kang, Kim \& Yang, 2016; Woo, et al., 2016; Yeo, 2017;). 그런데 적절한 언어 학습지원은 무엇이고 언제까지 지원을 해야 하는지? 그리고 언어의 어떠한 부분까지 학습지원 활동에 포 함해야 하는지에 대한 논제들이 거론되기 시작하면서 언어재활적 접근에서도 난독증을 살펴보기 시작하였다. 이러한 의미에서 서울 시교육청에서도 난독증 아동에 대한 지원을 언어재활사에게 의뢰 한 것이라 여겨진다.

본 연구자는 기존의 난독증 진단모델과 읽기와 관련된 대상자의
동반장애 특성, 그리고 읽기관련 변인(음운인식, 음운기억, 음운처 리능력[빠른 이름대기], 쓰기, 읽기이해, 듣기이해, 해독능력) 측정 결과가 어떻게 연관되어 해석될 수 있는지를 살펴보았다. 이에 다음 과 같은 기존의 3 가지 진단모델을 통해 난독증 의심증상을 보이는 초등학생 9명 대상자에 대해 기존 난독증 진단모델 별로 난독증을 진단하여 진단 결과에 있어 어떠한 차이가 있는지를 살펴보았다. 그리고 진단모델을 통한 난독증 진단 결과와 9명 난독증 대상자의 동반장애와의 연관성으로 난독증 집단을 구분하였다. 이후 해독 과 읽기 유창성 이외의 읽기와 관련된 변인들을 추가하여, 구분된 난독증 집단 별 읽기관련 변인 프로파일 분석을 진행하였다.

연구문제 1 의 연구결과, 기존의 세가지 진단모델에 따라서 난독 증을 진단하는 기준은 차이를 보이며 이에 따라 난독증 의심 대상 자 9명은 난독증으로 분류되기도 하고 그렇지 않기도 하였다. 이에 대해 자세히 살펴보면 다음과 같다. 첫째, 지능-성취 불일치모형을 적용하여 난독증을 진단한 결과 비언어성지능 환산점수가 90 이하 이며 REVT 표현어휘능력이 또래 평균 - $2 \mathrm{SD}$ 이하인 Jung $(8 ; 05, \mathrm{M})$ 과 REVT 수용 및 표현어휘능력 모두가 또래 평균 $-2 \mathrm{SD}$ 이하인 $\operatorname{Rae}(10 ; 07, \mathrm{~F})$ 아동 2명은 난독증 대상자에서 제외하였다. 이외 $\mathrm{Si}$ (6;11, M), Do (7;01, M), Tae (7;01, M), Seung (7;09, M), Yu (8;09, F), Hyun $(10 ; 00, \mathrm{~F})$, 그리고 $\mathrm{Da}(10 ; 04, \mathrm{M}) 7$ 명 아동은 불일치모형 난 독증 대상자에 포함되었다(Table 8). 둘째, RTI 모델은 읽기 중재 진 전도와 읽기성취수준을 함께 평가하여, 난독증 진단에서 중재의 진전도가 일정 정도 높게 나타난 아동은 난독관련 특수교육 대상 자에서 제외하도록 하는 것이다. 그리고 이번 연구에서는 KOLRA 의 해독과 ‘해독+유창성' 모두가 $45 \%$ 이상 또는 QRW의 읽기 진전 도가 $45 \%$ 이상으로 나타난 대상자는 RTI 모델 난독증 대상자에서 제외하도록 정의하였다. 이러한 정의 하에 Tae $(7 ; 01, \mathrm{M})$ 아동은 QRW 읽기능력 평가결과 $48.83 \%$ 의 진전도를 보여 RTI 모델 난독 증 대상에서 제외하였다. 그리고 Jung $(8 ; 05, \mathrm{M})$ 아동은 KOLRA 해 독과 ‘해독+유창성' 환산점수 진전도가 $168.42 \%, 50.59 \%$ 로 나타 나 RTI 모델 난독증 대상자에서 제외하였다. 이외 $\mathrm{Si}(6 ; 11, \mathrm{M})$, Do (7;01, M), Seung (7;09, M), Yu (8;09, F), Hyun (10;00, F), Da (10;04, $\mathrm{M})$, 그리고 Rae $(10 ; 07, \mathrm{~F}) 7$ 명 아동은 RTI 모델 난독증 대상자에 포 함되었다(Table 7). 셋째, 지능절단점 접근법에서는 평균적인 지능 의 범위를 $-2 \mathrm{SD}$ 이상으로 정하고 이러한 폭넓은 환산 지능점수대 에서 읽기능력이 저조한 대상자들을 난독증으로 정의하고 있다. 이 에 이번 연구에서는 9명 모든 대상자가 난독증에 포함되었다(Table 8).

이렇게 진단모델에 따라서 난독증이 구별되기도 하고 그렇지 않 기도 하였는데, 인지적인 문제가 심각한 수준인 대상자만을 제외 
하는 조건에서, 읽기검사를 진행한 결과만으로 난독증을 진단하 면 연구에 참여한 모든 9명 대상자는 해독과 읽기 유창성 모두에 문제를 보이는 난독증으로 구분될 수 있었다. 그리고 이러한 결과 는 지능이 읽기학습에 심각한 문제를 일으키는 범위가 아니라면 폭넓은 범위의 지능을 난독증으로 포함하는 것은 읽기 이외의 문 제를 포괄하는 대상자를 난독증에 포함하여 다양한 언어재활 치 료접근이 가능함을 시사한다.

KOLRA의 핵심검사(해독, 읽기이해, 읽기 유창성, 듣기이해) 평 가 결과 표준화점수 결과만을 이용하여 9명 난독증 대상자를 구분 하면 Si (6;11, M), Do (7;01, M), Tae (7;01, M), Seung (7;09, M), 4명 아동은 17-27점대의 해독, 80 점대의 읽기 이해력, 54-62점의 읽기 유창성, 100 점 이상의 평균이상 듣기 이해력을 가진 집단이라는 유 사성을 보이고 있었다. 그리고 Hyun $(10 ; 00, F)$ 과 Rae $(10 ; 07, F) 2$ 명 아동은 41-46점의 해독, 66-76점의 읽기 이해력, 58-68점의 읽기 유 창성, 98-103의 평균의 듣기 이해 유사성을 보이고 있었다. 이외 $\mathrm{Yu}$ $(8 ; 09, \mathrm{~F})$ 와 $\mathrm{Da}(10 ; 04, \mathrm{M}) 2$ 명 아동은 73-80점의 해독, 79-86점의 읽기이해, 56-60점의 읽기 유창성, 81-84점의 평균 이하의 듣기 이 해 유사성을 보이고 있었다. 그리고 마지막으로 Jung $(8 ; 05, \mathrm{M})$ 아 동은 핵심검사 결과에 있어 이외의 8 명 대상자 아동과는 다르게 19 점으로 해독능력이 낮은 편이었으며, 읽기 이해력도 67점으로 낮은 수준의 대상자였다. 하지만 읽기 유창성은 다른 난독증 대상자들 과 유사한 66점 수준이었고 듣기이해는 101점으로 평균의 정상적 인 수준인 것으로 나타났다. 즉 KOLRA 핵심검사 결과만으로 9명 전체 난독증 대상자를 4 개 집단으로 구분 가능하였다.

이러한 결과는 난독증 대상자의 해독 능력이 읽기이해와 읽기 유창성, 그리고 듣기이해력에 영향을 미치는 것은 아니라는 것을 의미했다. 기본적으로 이해하기에는 해독 점수가 듣기이해에 영향 을 미치지는 않지만, 해독 점수가 높을수록 읽은 것을 이해하고 유 창하게 읽는데 영향을 미칠 것으로 여겨진다. 하지만 읽는다는 것 과 듣기이해와 읽기이해는 별개의 영역이고, 단어를 읽을 수 있다 는 것과 유창하게 문장을 읽는다는 것도 별개의 과제로 나타나고 있었다. 즉, 이러한 결과에 대해 언어재활사는 난독증은 읽기와 읽 기이해, 읽기 유창성, 듣기이해라는 목표를 따로 구분하여 언어재 활 장기계획에 구분된 목표로 설정해야 함을 이해할 수 있었다. 그 리고 이번 연구결과에 제시된 KOLRA 점수 결과는 원점수가 아닌 표준화 환산점수를 적용한 것으로 또래 학년 수준에 따라 그 점수 가 적용된 것이다. 이러한 표준화 환산점수는 또래 수준과 바로 비 교할 수 있다는 편리함은 있지만, 원점수가 0 점이더라도 또래수준 에 맞추어 점수가 환산되므로 0 점이 아닌 90 점 이하의 점수로 제시 되었다는 문제가 있었다. 이러한 부분을 유념하여 결과에 대한 과
도한 해석은 자제하였다.

그리고 KOLRA 9개 소검사를 4 개 핵심검사와 5개 상세검사(음 운인식, 빠른 이름대기, 음운기억, 받아쓰기, 주제 글 쓰기) 둘로 나 누어 구분하여 분석한 결과, 4 개 핵심검사에서 유사한 결과 유형을 보인 4집단(1집단[Si (6;11, M), Do (7;01, M), Tae (7;01, M), Seung (7;09, M)], 2집단[Hyun (10;00, F), Rae (10;07, F)], 3집단[Yu (8;09, $\mathrm{F}), \mathrm{Da}(10 ; 04, \mathrm{M})], 4$ 집단[Jung $(8 ; 05, \mathrm{M})])$ 은 5 개 상세검사 원점수 에서는 유사한 결과 패턴이 나타나지는 않았다. 즉, 해독, 읽기이해, 듣기이해, 읽기 유창성이 난독증을 진단하는 부분에 있어 핵심검 사로 작용하지만 이러한 핵심검사 결과 나타나는 난독증 대상자 유형특성이 읽기와 관련된 변인인 상세검사 결과에도 유사하게 나 타나는 것은 아니었다. 이전 연구에 의하면 발달성 난독증은 그 정 의가 명확하지 않기에 진단에 대한 명확한 단일 개념이 존재하지 않는다고 보고하였다(Lyon et al., 2003). 이번 연구에서도 9명의 적 은 수의 대상자이지만 읽기와 관련된 다양한 측정 변인이 대부분 표준점수로 환산하였을 때 평균수준에 미달하였다는 것을 제외하 고는 모든 대상자들에게 공통된 특성으로 보이는 것은 없었다.

진단모델을 통한 난독증 진단결과와 9명 난독증 대상자 동반장 애와의 연관성으로 난독증 집단을 구분한 연구문제 2 의 연구결과 Si (6;11, M), Do (7;01, M), Yu (8;09, F), Hyun (10;00, F), Da (10;04, $\mathrm{M}), \operatorname{Rae}(10 ; 07, \mathrm{~F}) 6$ 명 아동은 진단모델과 동반장애(증상)와의 관 련성에 있어 DLD, SSD 동반 난독증 대상자를 포함하고 있으며, $\mathrm{Rae}$ 아동을 제외하고는 5명 아동이 진단모델 3가지 모두를 통해 난 독증으로 분류된 집단이었다. 이외 Tae $(7 ; 01, \mathrm{M})$ 와 Seung $(7 ; 09, \mathrm{M})$ 아동은 $\mathrm{ADHD}$ 를 동반하고 있으며 불일치모델(DS dyslexia), 지능 절단점 접근법(C-IQ dyslexia)에 의해 난독증 진단이 가능하다는 공통된 특성을 보이고 있었다. 그리고 Jung $(8 ; 05, \mathrm{M})$ 은 DLD와 TOT 동반증상을 보이며 지능절단점 접근법만으로 난독증으로 진 단 가능했던 대상자로 따로 구분되어 있었다(Figure 5 \& Table 11). 이러한 집단 분류는 위의 난독증 진단법이나 읽기능력 평가 결과 만으로 난독증을 분류한 집단과는 달리 구분되는 집단의 수를 동 반장애의 주요 특징에 의해 크게 분류하고 동반증상이 몇 개 포함 되어 있는지에 따라 집단을 분류하여 분류 집단의 수가 이전보다 는 축소된 3집단으로 분류 가능하였다. 이러한 집단 분류가 읽기능 력 관련 변수 평가 프로파일 분석에서는 어떻게 나타날 지는 연구 문제 3 을 통해 살펴보았다.

연구문제 3에서는 해독과 이해, 읽기 유창성 이외의 읽기와 관련 된 변인들을 추가 평가하여, 연구문제 2에서 진단모델과 동반장애 (증상)와의 연관성 상응분석 결과로 나누어진 세 집단(DLD, SSD 동반 또는 일반 난독증 집단, $\mathrm{ADHD}$ 동반 난독증 집단, $\mathrm{DLD}$ 와 
TOT를 동반한 아동) 별 읽기관련 변인(음운 \& 인지처리, 음운기억, 언어능력[어휘능력, 듣기/읽기이해, 쓰기]) 프로파일을 분석하여 그 차이를 살펴보았다(Figures 7, 8, 9, 10). 연구결과, 지능과 표현어휘, 음운인식 능력은 DLD와 TOT 2가지 증상을 동반한 아동이 가장 낮았으며, 나머지 아동들은 유사하게 저조한 능력을 보였다. 그리 고 $\mathrm{QRW}$ 단어와 문장 읽기능력은 $\mathrm{ADHD}$ 동반 난독증 아동이 나 머지 집단에 비하여 특히 저조한 능력을 보였다. 하지만 KOLRA의 읽기 유창성 검사 결과는 $\mathrm{DLD}$ 와 TOT 동반 아동이 가장 높은 점 수를 보이고 나머지 2집단은 유사하였다, 이러한 결과는 난독증 대 상자들이 읽기과제에 있어 단어와 문장, 문단에 따라 그 정확성과 빠르기가 다르다는 것을 의미한다. 그러므로 난독증 대상자에게는 동일한 과제이더라도 문장의 길이와 난이도 음소결합 조건에 따라 그 결과가 다양할 수 있음을 시사한다. 그리고 해독과 단어 문장 받 아쓰기 능력이 DLD, SSD 동반 또는 일반 난독증 집단이 다른 나머 지 난독증 2집단에 비하여는 높게 나타났다. 이는 DLD 난독 집단 이 다른 집단에 비하여 학년이 높다는 특성에 의해 나타난 결과로 보여 진다. 듣기이해력은 세 집단 모두 90점 이상으로 또래와 유사 한 평균수준을 보였으며, 세 집단 간 비교하였을 때는 $\mathrm{ADHD}$ 동반 난독증 집단이 가장 높은 점수를 받은 것으로 나타났다. 즉, 듣고 이해하는 능력은 모든 난독증 대상 아동이 평균 수준을 보였다. 그 리고 빠른 이름대기는 $\mathrm{Si}(6 ; 11, \mathrm{M})$ 아동이 특히 느리게 반응했을 뿐 대부분의 아동은 이름대기 속도가 유사하였다.

연구문제에 대한 결과를 종합하여 언어재활사들을 위한 언어발 달 측면에서의 난독증 진단모델과 평가안에 대해 논의하면 다음과 같다(Table 12). 1) 난독증 진단모델별로 대상자 잠재능력과 성취수 준의 차이에 대한 난독증 정의는 달랐다. 그리고 이러한 연유로 난 독증 의심 대상자를 적용 진단모델에 따라 분류한 결과 난독증으 로 진단되기도 하고 아니기도 하였다. 언어발달 전반을 다루는 언 어재활사의 입장에서는 난독증 대상자의 잠재능력에 대해 언어능
력과 지능을 함께 제한하기보다는 비언어성지능이 평균 $-2 \mathrm{SD}$ 이 상으로, 인지능력 결함으로 읽기 문제를 보이지 않는다는 배제요인 에 대해서만 제한을 두는 것이 바람직한 것으로 보인다. 왜냐하면 학령기 이후 읽기능력은 언어능력에 많은 영향을 미치기 때문에, 언어능력을 제한한다는 것은 읽기능력의 문제로 언어능력이 저조 한 난독증 대상자를 진단하는데 제한적 요소로 작용할 수 있기 때 문이다. 이에 학령기 이후에 난독증으로 의심되는 아동을 진단할 때는 아동의 연령에 따라 읽기 문제만으로 난독증을 평가하는 것 이 적합하다고 여겨진다.

2) 난독증을 진단하는 성취수준의 차이는 표준화된 읽기검사에 서 해독과 읽기 유창성 검사 결과가 또래 수준에 비하여 평균 -1.5 $\mathrm{SD}$ 이하인 아동을 대상으로 하는 것이 바람직하다. 이는 DSM-5 (APA, 2013)와 동일한 기준으로 읽기의 문제가 심각한 난독 대상 자에게는 이러한 기준을 벗어나는 것은 어려울 것으로 보이기 때문 이다.

3) KOLRA에서는 핵심검사에 해독과 읽기 유창성 이외에 읽기 와 듣기이해 능력을 함께 평가하여 난독증 아동의 유형을 분류하 고 있다. 언어발달의 측면에서는 난독증 대상자가 해독 또는 읽기 유창성 이외에 읽은 것을 이해하는 능력과 듣고 이해하는 능력을 평가하는 것은 중요한 부분이다. 읽기는 읽기이해를 목표로 진행되 는 행위이다. 그런데 읽은 내용을 이해하지 못한다는 것은 언어재 활사의 입장에서는 어휘능력 문제인지 구문 이해력의 문제인지를 파악하여 적절한 장단기목표를 설정하는데 있어 중요한 부분이다. 그리고 듣기이해 능력은 청각적 음운지각 능력과 음운기억 능력이 포함된 능력으로 읽기이해와는 다른 처리 능력이 요구된다. 그러므 로 듣기이해 능력을 평가하는 것은 대상자의 읽기특성의 취약점을 파악하는 데 필요한 부분이며 대상자의 장단기 치료계획에 있어 목표 설정에 중요한 부분을 차지할 수 있다.

4) 동반장애 유형에 따라 난독증을 분류한 결과 $\mathrm{DLD}$ 와 $\mathrm{ADHD}$,

Table 12. Diagnosis model and evaluation contents of dyslexia by language development

\begin{tabular}{ll}
\hline Dimensions & Lssessing dyslexia in terms of language development \\
Purpose & $\begin{array}{c}\text { Children with dyslexia had low word reading in the presence of "normal" intelligence with no stipulation of a discrepancy } \\
\text { between IQ and word reading abilities }\end{array}$ \\
& Nonverbal IQ measures and liberal cutoff (within 2 SDs of the mean) \\
Potential & Decoding, paragraph reading fluency (under -1.5 SDs of the mean) \\
Performing evidence & Reading comprehension, Listening comprehension \\
Additional Reading Assessment & Phonological awareness, Phonological memory, Phonological processing competence (Rapid naming) \\
& Writing (Dictation about word, sentence; Topic article) \\
Comorbidity & DLD, ADHD, SSD, TOT and so on \\
\hline
\end{tabular}

$\mathrm{IQ}$ = intelligence quotient; $\mathrm{ADHD}=$ attention deficit hyperactivity disorders; $\mathrm{DLD}=$ developmental language disorders; $\mathrm{SD}=$ standard deviation; $\mathrm{SSD}=$ speech sound disorders; TOT = tip of the tongue. 
$\mathrm{SSD}, \mathrm{TOT}$ 증상에 따라 난독증 집단 분류가 가능하였다. 동반장애 분류 아동 중 $\mathrm{DLD}$ 와 TOT를 모두 동반한 난독증 아동은 해독, 읽 기 유창성, 읽기이해가 다른 난독증 아동에 비하여 가장 지체된 것 으로 나타났으며 듣기이해 능력은 평균적인 능력을 보이고 있었다. $\mathrm{ADHD}$ 아동은 해독과 읽기 유창성 능력에 비하여 읽기와 듣기이 해 능력이 모두 다른 동반장애 난독증 아동에 비하여 높은 것으로 나타났다. 그리고 $\mathrm{DLD}, \mathrm{SSD}$ 를 포함한 난독증 아동은 해독 능력은 다른 동반장애 난독증 집단보다 높았으나 이에 비해 듣기이해 능력 이 저조한 것으로 나타났다. 이처럼 동반장애 여부가 난독증의 읽 기관련 평가 결과 집단을 분류하는데 영향을 미친 결과를 참조하 여, 동반장애가 난독증 대상자의 읽기특성에 미치는 영향을 이해 하고 있어야 한다.

5) 난독증 대상자의 동반장애와 읽기관련 변인(음운인식, 음운 기억, 음운처리능력[빠른 이름대기], 쓰기, 읽기이해, 듣기이해, 해 독능력) 측정 결과와의 연관성을 분석한 결과, 난독증에 대한 진단 핵심검사로 분류되어 있는 해독, 읽기이해, 읽기 유창성, 듣기이해 는 동반장애 또는 읽기능력에 따라 난독증을 분류하는데 영향을 미치고 있었다. 하지만 이러한 분류에 의해 구분된 핵심검사 결과 는 읽기능력 세부검사(음운인식, 음운기억, 음운처리능력 $[$ 빠른 이 름대기], 쓰기)와는 관련이 없었다. 즉, 핵심검사 이외에 세부검사 를 살피는 것은 난독증을 분류하는 또 다른 측정 결과로 작용하고 있었다. 이에 세부검사는 난독증을 진단하는 측면이 아닌 대상자 의 특성을 파악하는 추가 검사로써 진행하는 것을 권고한다.

이번 연구는 언어재활사의 입장에서 언어발달 측면을 고려하여 난독증을 진단하여 보고 그 결과를 종합하여 언어발달 접근법에 서의 난독증 진단모델과 평가안을 제시하였다. 이러한 연구는 난 독증을 진단하는 내용에 기존의 해독과 읽기 유창성, 그리고 음운 인식 측면으로만 접근하는 것이 아닌 다양한 언어측면을 고려해야 함을 제시하였다는데 의의가 있다. 또한 난독증 대상자의 동반장 애 측면에서 난독증 대상자의 읽기능력을 평가하여 보고 그 결과 를 제시하였다는 것도 의미가 있다.

마지막으로 연구의 제언은 다음과 같다. 이번 연구는 난독증을 진단하는 것을 단일시점 또는 2 가지 시점(RTI model)에서 평가하 여 난독증을 평가하였다. 하지만 언어발달 측면에서 살펴보기 위해 서는 종단적인 측면에서 난독증 대상자들의 언어능력과 읽기능력 을 평가하고 이러한 평가 결과의 변화를 살펴보아야 할 것이다. 이 에 추후 연구에서는 난독증 대상자들의 종단적인 진단을 통한 평 가 결과를 살펴보기를 제안한다. 특히, 읽기학습 능력이 저조하여 학습부진으로 진단된 초등학교 고학년 이상의 대상자들에 대해 난독증을 진단하고 평가해보기를 권고한다. 이들은 난독의 문제로
학습 능력이 또래보다 저조하였을 가능성이 있는데 이러한 원인에 대한 재활이 배제된 상황에서 보충학습이 이루어진 대상자도 포함 되어 있을 수 있다. 이들 대상자들이 진짜 난독증인지를 진단하고 평가하는 것은 학령초기와는 다른 문제일 가능성이 크다. 그리고 이번 연구에는 난독증과 유전적 요인과의 관계를 살펴보지는 못하 였다. 난독증은 유전적 요인이 많이 영향을 미치는 장애로 알려져 있다. 이에 학령전기의 읽기능력 측정이 이루어지기 전의 난독증 대상자의 언어발달을 살펴보기 위해서는 유전적 요인이 있는 가정 의 아동들을 대상으로 언어능력과 읽기발달을 종단적으로 살펴보 기를 권고한다. 이러한 연구는 난독증 아동의 학령전기 언어발달 을 살펴볼 수 있는 기회를 제공해 줄 것이다. 그리고 이번 연구는 9명이라는 적은 수의 대상자를 통해 난독증 진단모델의 적합성을 살펴보았다. 이는 연구결과에 대한 신뢰도를 확보하는데 어려움이 있다는 제한점을 가진다. 이후 계속적인 대상자 확보를 통해 좀 더 신뢰도 있는 자료를 확보하기를 기대한다.

\section{REFERENCES}

Adlof, S. M., \& Hogan, T. P. (2018). Understanding dyslexia in the context of developmental language disorders. Language, Speech, and Hearing Services in Schools, 49(4), 762-773.

Alt, M., Hogan, T., Green, S., Gray, S., Cabbage, K., \& Cowan, N. (2017). Word learning deficits in children with dyslexia. Journal of Speech, Language, and Hearing Research, 60(4), 1012-1028.

Alt, M., Gray, S., Hogan, T. P., Schlesinger, N., \& Cowan, N. (2019). Spoken word learning differences among children with dyslexia, concomitant dyslexia and developmental language disorder, and typical development. Language, Speech, and Hearing Services in Schools, 50(4), 540-561.

American Psychiatric Association. (2013). Diagnostic and statistical manual of mental disorder (5th ed.). Washington, DC: American Psychiatric Association.

Arciuli, J. (2018). Reading as statistical learning. Language, Speech, and Hearing Services in Schools, 49(3S), 634-643.

Bishop, D. V. M., Snowling, M. J., Thompson, P. A., Greenhalgh, T., \& CATALISE-2 consortium. (2017). Phase 2 of CATALISE: a multinational and multidisciplinary Delphi consensus study of problems with language development: terminology. The Journal of Child Psychology and Psychiatry, 58(10), 1068-1080.

Bogdanowicz, K. M., \& Bogdanowicz, M. (2016). “The Good Start Method for English" or how to support development, prevent and treat risk of dys- 
lexia in children learning English as a second language. Polish Psychological Bulletin, 47(3), 265-269.

Bulgarelli, F., Lebkuecher, A. L., \& Weis, D. J. (2018). Statistical learning and bilingualism. Language, Speech, and Hearing Services in Schools, 49(3S), 740-753.

Buonincontri, R., Bache, I., Silahtaroglu, A., Elbro, C., Nielsen, A-M. V., Ullmann, R., Arkesteijn, G., \& Tommerup, N. (2011). A cohort of balanced reciprocal translocations associated with dyslexia: Identification of two putative candidate genes at DYX1. Behavior Genetics, 41(1), 125-133.

Cabbage, K. L., Farquharson, K., Iuzzini-Seigel, J., Zuk, J., \& Hogan, T. P. (2018). Exploring the overlap between dyslexia and speech sound production deficits. Language, Speech, and Hearing Services in Schools, 49(4), 774-786.

Catts, H. W., Fey, M. E., Tomblin, J. B., \& Zhang, X. (2002). A longitudinal investigation of reading outcomes in children with language impairments. Journal of Speech, Language, and Hearing Research, 45(6), 1142-1157.

Catts, H. W., Adlof, S. M., Hogan, T. P., \& Weismer, S. E. (2005). Are specific language impairment and dyslexia distinct disorders? Journal of Speech, Language, and Hearing Research, 48(6), 1378-1396.

Cho, K., Jung, J., \& Nam, K. (2002). Lexical processing in acquired hangul dyslexia. Korean Journal of Communication Disorder, 7(3), 1-20.

Christmann, C. A., Lachmann, T., \& Steinbrink, C. (2015). Evidence for a general auditory processing deficit in developmental dyslexia from a discrimination paradigm using speech versus nonspeech sounds matched in complexity. Journal of Speech, Language, and Hearing Research, 58(1), 107121.

Daikhin, L., Raviv, O., \& Ahissar, M. (2017). Auditory stimulus processing and task learning are adequate in dyslexia, but benefits from regularities are reduced. Journal of Speech, Language, and Hearing Research, 60(2), 471479.

De Groot, B. J. A., Van den Bos, K. P., Van der Meulen, B. F., \& Minnaert, A. E. M. G. (2015). Rapid naming and phonemic awareness in children with reading disabilities and/or specific language impairment: differentiating processes? Journal of Speech, Language, and Hearing Research, 58(5), 15381548.

De Luca, M., Marinelli, C. V., Spinelli, D., \& Zoccolotti, P. (2017). Slowing in reading and picture naming: the efects of aging and developmental dyslexia. Experimental Brain Research, 235(10), 3093-3109.

Duranovic, M., Tinjak, S., \& Turbic-Hadzagic, A. (2014). Morphological knowledge in children with dyslexia. Journal of Psycholinguistic Research, 43(6), 699-713.
Eellis, N. C., \& Hooper, A. M. (2001). Why learning to read is easier in Welsh than in English: orthographic transparency effects evinced with frequency-matched tests. Applied Psycholinguistics, 22(4), 571-599.

Faust, M., Dimitrovsky, L., \& Shacht, T. (2003). Naming difficulties in children with dyslexia: application of the tip-of-the-tongue paradigm. Journal of Learning Disabilities, 36(3), 203-215.

Gabay, Y., Thiessen, E. D., \& Holt, L. L. (2015). Impaired statistical learning in developmental dyslexia. Journal of Speech, Language, and Hearing Research, 58(3), 934-945.

Geiser, E., Kjelgaard, M., Christodoulou, J. A., Cyr, A., \& Gabrieli, J. D. E. (2014). Auditory temporal structure processing in dyslexia: processing of prosodic phrase boundaries is not impaired in children with dyslexia. Annal of Dyslexia, 64(1), 77-90.

Gough, P. B., \& Tunmer, W. E. (1986). Decoding, reading, and reading disability. RASE: Remedial and Special Education, 7(1), 6-10.

Gray, S., Fox, A. B., Green, S., Alt, M., Hogan, T. P., Petscher, Y., \& Cowan, N. (2019). Working memory profiles of children with dyslexia, developmental language disorder, or both. Journal of Speech, Language, and Hearing Research, 62(6), 1839-1858.

Griffiths, Y. M., \& Snowling, M. J. (2001). Auditory word identification and phonological skills in dyslexic and average readers. Applied Psycholinguistics, 22(3), 419-439.

Hanly, S., \& Vandenberg, B. (2010). Tip-of-the-tongue and word retrieval deficits in dyslexia. Journal of Learning Disabilities, 43(1), 15-23.

Hakvoort, B., de Bree, E., van der Leij, A., Maassen, B., van Setten, E., Maurits, N., \& van Zuijen, T. L. (2016). The role of categorical speech perception and phonological processing in familial risk children with and without dyslexia. Journal of Speech, Language, and Hearing Research, 59(6), 14481460.

Hachmann, W. M., Bogaerts, L., Szmalec, A., Woumans, E., Duyck, W., \& Job, R. (2014). Short-term memory for order but not for item information is impaired in developmental dyslexia. Annals of Dyslexia, 64(2), 121-136.

Hendricks, A. E., Adlof, S. M., Alonzo, C. N., Fox, A. B., \& Hogan, T. P. (2019). Identifying children at risk for developmental language disorder using a brief, whole-classroom screen. Journal of Speech, Language, and Hearing Research, 62(4), 896-908.

Ho, C. S. H., \& Fong, K. M. (2005). Do Chinese dyslexic children have difficulties learning English as a second language? Journal of Psycholinguistic Research, 34(6), 603-618.

Holttum, S. (2016). Dyslexia: is it genetic and what does this mean for social 
inclusion? Mental Health and Social Inclusion, 20(4), 202-207.

Hwang, K. H. (2015). Revision of the national curriculum and response tasks of teacher's policy. Collection of materials for the 68th annual conference of the Korean teachers and education association. Seoul.

Individuals with Disabilities Education Improvement Act, P. L. 108-446 (2004). Jung, E. J. (2013). Discussions on the implications of the change in the diagnosis of learning disabilities in DSM-5 on diagnosis and determination of learning disabilities in Korea. Paper presented at the meeting of the Spring Conference of the Korean Association of Learning Disabilities. Seoul.

Jung, H. S. (2018). Effects of dynamic response to intervention model on reading disability diagnostic rate - application of the phonics program combining phonological awareness for 7-year-olds. The Korea Journal of Learning Disabilities, 15(3), 231-250.

Kapoula, Z., Lê, T-T., Bonnet, A., Bourtoire, P., Demule, E., Fauvel, C., Quilicci, C., \& Yang, Q. (2010). Poor stroop performances in 15-year-old dyslexic teenagers. Experimental Brain Research, 203(2), 419-425.

Kim, D. I., Kim, H. J., An, Y. J., Ahn, S. J., Im, H. J., \& Hwang, J. Y. (2017). An application study of RTI for identifying students with dyslexia: focused on the reading fluency program. The Korean Journal of Educational Psychology, 31(2), 265-282.

Kim, D. I., Kim, H. J., Kim, H. E., \& Ahn, S. J. (2018). Analysis of effects of program for the dyslexia and reading difficulties: focused on the Gyeonggi-do project of the dyslexia program. Asian Journal of Education, 19(2), 403-427.

Kim, S. H., \& Cho, Y. A. (2010). Clinical characteristics of patients with dyslexia in Korea: correlation with meares-irlen syndrome. Journal of Korean Ophthalmological Society, 51(12), 1639-1642.

Kim, W. R., \& Koh, H. J. (2014). Procedures and criteria to identify reading disabilities in South Korea. Asian Journal of Education, 15(2), 83-110.

Kim, Y. J., Lee, M. A., \& Jeong, J. H. (2011). Relationships between reading ability and binocular vision. Journal of Korean Ophthalmic Optics society, 16(2), 171-177.

Kim, Y. T., Hong, K. H., Kim, K. H., Jang, H. S., \& Lee, J. Y. (2009). Receptive \& Expressive Vocabulary Test (REVT). Seoul: Seoul Community Rehabilitation Center.

Kim, Y. T., Jai, H., Jung, K., Kim, Y. R., Pae, S., Choi, E. J., \& Jung, S. I. (2020). Validity and sensitivity · specificity of Quick Assessment of Childhood Reading \& Writing. Communication Science \& Disorders, 25(1), 1-13.

Kim, Y. T., Shin, M. J., Kim, S. J., \& Ha, J. W. (2020). Urimal Test of Articulation and Phonology 2 (U-TAP 2). Seoul: Inpsyt (division of Hakjisa Pub- lisher, Inc.).

Law, S. P., \& Yeung, O. (2010). Effects of age of acquisition and semantic transparency on reading characters in Chinese dyslexia. Applied PsycholinGuistics, 31(4), 711-733

Lee, A., \& Lee, Y. (2019). An analysis of the local ordinance for supporting to students with dyslexia. Korean Journal of Special Education, 54(1), 91-119.

Lee, A., \& Yang, M. (2018). Examining information that helps teacher's judgment on learning difficulties and disabilities. The Korea Journal of Learning Disabilities, 15(3), 29-55.

Lee, D. (2017). An analysis of the current and proposed laws on supporting students with low achievement. The Korea Journal of Learning Disabilities, 14(3), 49-75.

Lee, D. (2019). How do we understand and tackle learning difficulties? tasks and visions for the development of educating students with learning disabilities in Korea. The Korea Journal of Learning Disabilities, 16(1), 1-32.

Lee, H. J., Kim, M. R., \& Nam, K. C. (1998). Toward understanding dyslexia: classification and evaluation of dyslexia. The Korean Journal of Psychology: General, 17(1), 1-24.

Lee, S. J., Park, J. H., Lee, S. H., Whang, K. H., \& Ryu, G. C. (2011). The study on improvement of reading ability for dyslexia wearing color filter lens (ChromaGen(TM) Lens). Journal of Korean Ophthalmic Optics society, 16(1), 65-74

Leonard, L. B. (2014). Children with specific language impairment. Cambridge, MA: MIT Press.

Li, W. S., \& Ho, C. S. H. (2011). Lexical tone awareness among Chinese children with developmental dyslexia. Journal of Child Language, 38(4), 793808.

Łockiewicz, M., \& Jaskulska, M. (2019). NL reading skills mediate the relationship between NL phonological processing skills and a foreign language (FL) reading skills in students with and without dyslexia: a case of a NL (Polish) and FL (English) with different degrees of orthographic consistency. Annals of Dyslexia, 69(2), 219-242.

Lyon, G. R., Shaywitz, S. E., \& Shaywitz, B. A. (2003). Defining dyslexia, comorbidity, teachers' knowledge of language and reading: a definition of dyslexia. Annals of Dyslexia, 53, 1-14.

McArthur, G. M., Hogben, J. H., Edwards, V. T., Heath, S. M., \& Mengler, E. D. (2000). On the "specifics" of specific reading disability and specific language impairment. Journal of Child Psychology and Psychiatry, and Allied Disciplines, 41(7), 869-874.

McGee, R., Brodeur, D., Symons, D., Andrade, B., \& Fahie, C. (2004). Time 
perception: does it distinguish $\mathrm{ADHD}$ and $\mathrm{RD}$ children in a clinical sample? Journal of Abnormal Child Psychology, 32(5), 481-490.

Ministry of Education. (2014). Conditions and procedures for selecting students with learning disabilities. Seoul: Ministry of Education of the Republic of Korea.

Ministry of Education. (2015). Comments on the 2015 Revised Curriculum. Seoul: Ministry of Education of the Republic of Korea (No. 11-1342000000188-01). Seoul: Ministry of Education of the Republic of Korea.

Moll, K., Hulme, C., Nag, S., \& Snowling, M. J. (2015). Sentence repetition as a marker of language skills in children with dyslexia. Applied Psycholinguistics, 36(2), 203-221.

Na, K. E., \& Seo, Y. J. (2013). Changes in diagnostic criteria of specific learning disorders in DSM-5 and its implications on the identification of students with learning disabilities in South Korea. The Korea Journal of Learning Disabilities, 10(3), 53-77.

National Institute of Neurological Disorders and Stroke. (2017). Dyslexia information page what research is being done? https://www.ninds.nih.gov/ Disorders/All-Disorders/Dyslexia-Information-Page.

Nolan, K. A., Volpe, B. T., \& Burton, L. A. (1996). The continuum of deep/ surface dyslexia. Journal of Psycholinguistic Research, 26(4), 413-424.

Obidziński, M., \& Nieznański, M. (2017). False memory for orthographically versus semantically similar words in adolescents with dyslexia: a fuzzytrace theory perspective. Annals of Dyslexia, 67(3), 318-332.

Pacheco, A., Reis, A., Arau'jo, S., Ina'cio, F., Petersson, K. M., \& Fa1'sca, L. (2014). Dyslexia heterogeneity: cognitive profiling of Portuguese children with dyslexia. Reading and Writing, 27(9), 1529-1545.

Pae, S., Kim, M., Yoon, H., \& Jang, S. (2015). Korean Language based Reading Assessment (KOLRA). Seoul: Hakjisa.

Park, H. (2014). Korean version of Comprehensive Test of Nonverbal Intelligence Second Edition (K-CTONI-2). Seoul: Mind Press.

Pennington, B. F., Gilger, J. W., Olson, R. K., \& DeFries, J. C. (1992). The external validity of age-versus IQ-discrepancy definitions of reading disability: lessons from a twin study. Journal of Learning Disabilities, 25(9), 562573.

Redmond, S. M., Ash, A. C., \& Hogan, T. P. (2015). Consequences of co-occurring Attention-Deficit/Hyperactivity Disorder on children's language impairments. Language, Speech, and Hearing Services in Schools, 46(2), 6880.

Rutter, M., Caspi, A., Fergusson, D., Horwood, L. J., Goodman, R., Maughan, B., ... \& Carroll, J. (2004). Sex differences in developmental reading dis- ability: new findings from 4 epidemiological studies. Journal of the American Medical Association, 291(16), 2007-2012.

Scerri, T. S., \& Schulte-Korne, G. (2010). Genetics of developmental dyslexia. European Child \& Adolescent Psychiatry, 19(3), 179-197.

Shareef, Z., Östberg, P., \& Hedenius, M. (2019). Verbal fluency in relation to reading ability in students with and without dyslexia. Applied Psycholinguistics, 40(2), 445-472.

Shaywitz, S. E., Shaywitz, B. A., Fletcher, J. M., \& Escobar, M. D. (1990). Prevalence of reading disability in boys and girls. Journal of the American Medical Association, 264(8), 998-1002.

Shaywitz, S. E. (1996). Dyslexia. Scientific American, 275(5), 98-104.

Shaywitz, S. E., \& Shaywitz, B. A. (2008). Paying attention to reading: the neurobiology of reading and dyslexia. Development and Psychopathology, 20(4), 1329-1349.

Son, S. H., Kang, O. R., Kim, S., \& Yang, M. (2016). Exploring the effects of tier 2 vocabulary intervention for students who are at-risk for reading disability. The Korea Journal of Learning Disabilities, 13(1), 1-26.

Spencer, M., Wagner, R. K., Schatschneider, C., Quinn, J. M., Lopez, D., \& Petscher, Y. (2014). Incorporating RTI in a hybrid model of reading disability. Learning Disability Quarterly, 37(3), 161-171.

Stanovich, K. E. (1991). Discrepancy definitions of reading disabilities: has intelligence led us astray? Reading Research Quarterly, 26(1), 7-29.

Sumner, E., Connelly, V., \& Barnett, A. L. (2013). Children with dyslexia are slow writers because they pause more often and not because they are slow at handwriting execution. Reading and Writing, 26(6), 991-1008.

Taylor, K. E. (2004). Familial cancer and developmental dyslexia: an observational pilot study. Developmental Medicine and Child Neurology, 46(2), 119127.

Torgesen, J. K. (2000). Individual differences in response to early interventions in reading: the lingering problem of treatment resisters. Learning Disabilities Research \& Practice, 15(1), 55-64.

Treiman, R. (2018). Statistical learning and spelling. Language, Speech, and Hearing Services in Schools, 49(3S), 644-652.

Tunmer, W., \& Greaney, K. (2010). Defining dyslexia. Journal of Learning Disabilities, 43(3), 229-243.

Vadasy, P. F., Sanders, E. A., \& Abbott, R. D. (2008). Effects of supplemental early reading intervention at 2 -year follow up: reading skill growth patterns and predictors. Scientific Studies of Reading, 12(1), 51-89.

Vallar, G., Burani, C., \& Arduino, L. S. (2010). Neglect dyslexia: a review of the neuropsychological literature. Experimental Brain Research, 206(2), 
219-235.

van Viersen, S., de Bree, E. H., Kalee, L., Kroesbergen, E. H., \& de Jong, P. F.

(2017). Foreign language reading and spelling in gifted students with dyslexia in secondary education. Reading and Writing, 30(6), 1173-1192.

van Viersen, S., de Bree, E. H., Verdam, M., Krikhaar, E., Maassen, B., van der

Leij, A., \& de Jong, P. F. (2017). Delayed early vocabulary development in children at family risk of dyslexia. Journal of Speech, Language, and Hearing Research, 60(4), 937-949.

Vellutino, F. R., Scanlon, D. M., Sipay, E. R., Small, S. G., Pratt, A., Chen, R., \& Denckla, M. B. (1996). Cognitive profiles of difficult-to-remediate and readily remediated poor readers: early intervention as a vehicle for distinguishing between cognitive and experiential deficits as basic causes of specific reading disability. Journal of Educational Psychology, 88(4), 601-638.

Vellutino, F. R., Scanlon, D. M., \& Reid Lyon, G. (2000). Differentiating between difficult-to-remediate and readily remediated poor readers: more evidence against the IQ-achievement discrepancy definition of reading disability. Journal of Learning Disabilities, 33(3), 223-238.

Whiteley, H. E., Smith, C. D., \& Connors, L. (2007). Young children at risk of literacy difficulties: factors predicting recovery from risk following phonologically based intervention. Journal of Research in Reading, 30(3), 249-269.
Wijnen, F., Kappers, A. M. L., Vlutters, L. D., \& Winke, S. (2012). Auditory frequency discrimination in adults with dyslexia: a test of the anchoring hypothesis. Journal of Speech, Language, and Hearing Research, 55(5), 13871394.

Wimmer, H., Mayringer, H., \& Landerl, K. (2000). The double deficit hypothesis and difficulties in learning to read a regular orthography. Journal of Educational Psychology, 92(4), 668-680.

Wolf, M. (1999). What time may tell: towards a new conceptualization of developmental dyslexia. Annals of Dyslexia, 49(1), 1-28.

Woo, J. H., Kim, Y. S., Kim, Y. O., Kang, O, R., Kim, S. H., \& Hur, S. J. (2016). Comparative Analysis among Stakeholder Groups on Support Needs for Students with Dyslexia. The Korea Journal of Learning Disabilities, 13(1), 53-83.

Yeo, S. (2017). Universal screening for early identification of students at risk for reading: an application of curriculum based measurement. The Korea Journal of Learning Disabilities, 14(3), 77-99.

Yoo, H., Jung, J., Lee, E. K., Kang, S. H., Park, E. H., \& Choi, I. (2016). Standardization of the comprehensive learning test-reading for the diagnosis of dyslexia in Korean children and adolescents. Journal of the Korean Academy of Child and Adolescent Psychiatry, 27(2), 109-118. 


\section{국문초록}

\section{발달성 난독증 진단: 난독증 의심 증상을 보이는 한국 초등학생 9 명을 대상으로 이은주 $\cdot$ 김영태 ${ }^{2}$ \\ ${ }^{1}$ 이화여자대학교 특수교육연구소, ${ }^{2}$ 이화여자대학교 언어병리학과}

배경 및 목적: 난독증 진단모델과 동반장애 특성, 그리고 다양한 읽기관련 변인 측정 결과가 어떻게 연관되어 난독증 진단 결과를 해석 할 수 있는지를 살펴보았다. 방법: 난독증 의심증상을 보이는 초등학생 9 명 대상자를 기존의 진단모델을 통해 진단한 결과 차이를 살펴 보았다. 그리고 진단모델을 통한 진단결과와 난독증 대상자의 동반장애와의 연관성을 상응분석 하였다. 마지막으로 상응분석 결과 난 독증 집단에 대해 읽기관련 변인 프로파일 분석을 진행하였다. 결과: 연구문제 1 의 분석결과, 세가지 진단모델에서 난독증을 진단하는 기준은 차이를 보이며 이에 따라 난독증 의심 대상자 9 명은 난독증으로 분류되기도 하고 그렇지 않기도 하였다. 연구문제 2 의 상응분 석결과 $\mathrm{DLD}$ 와 $\mathrm{ADHD}, \mathrm{SSD}, \mathrm{TOT}$ 동반 장애 및 증상에 따라 난독증 진단 집단 분류가 가능하였다. 그리고 연구문제 3 분석결과 난독 증 진단 핵심검사로 분류되어 있는 해독, 읽기이해, 읽기 유창성, 듣기이해는 동반장애 또는 읽기능력에 따라 난독증을 분류하는데 영 향을 미치고 있었다. 하지만 이러한 분류에 의해 구분된 난독 핵심검사 결과는 읽기능력 세부검사(음운인식, 음운기억, 음운처리능력, 쓰기)와는 관련이 없었다. 논의 및 결론: 이번 연구는 언어재활사의 입장에서 언어발달 측면을 고려하여 난독증을 진단하여 보고 그 결과를 종합하여 언어발달 접근법에서 난독증 진단모델과 평가안을 제시하였다.

핵심어: 난독증, 진단모델, 동반장애, 언어발달

본 연구는 2020년 대한민국 교육부와 한국연구재단의 지원을 받아 수행된 연구임(No. NRF-2018S1A3A2075274).

\section{참고문헌}

교육부(2014). 학습장애학생 선정 조건 및 절차. 서울: 대한민국 교육부.

교육부(2015). 2015 개정 교육과정 총론 해설(발간등록번호: 11-1342000-000188-01). 서울: 대한민국 교육부.

국립특수교육원(2019). 학습장애학생 교육지원 방안(발간등록번호: 11-1342075-000223-01). 충남아산: 국립특수교육원.

김동일, 김희주, 안예지, 안성진, 임희진, 황지영(2017). 난독증 선별을 위한 RTI 적용. 교육심리연구, 31(2), 265-282.

김동일, 김희주, 김희은, 안성진(2018). 난독증 및 읽기 부진 학생 대상 프로그램의 효과 분석: 난독증 아동청소년 전문치료프로그램을 중심으로. 아

시아교육연구, 19(2), 403-427.

김승현, 조윤애(2010). 난독증을 주소로 내원한 한국인 환자들의 임상양상: 얼렌증후군과의 연관성. 대한안과학회지, 51(12), 1639-1642.

김영지, 이민아, 정주현(2011). 읽기능력과 양안시기능의 관계성. 한국안광학회지, 16(2), 171-177.

김영태, 홍경훈, 김경희, 장혜성, 이주연(2009). 수용·표현어휘력검사. 서울: 서울장애인종합복지관.

김영태, 제현순, 정경희, 김영란, 배소영, 최은정, 정상임, 김효창(2020). 아동 간편 읽기 및 쓰기 발달 검사(QRW) 개발을 위한 타당도 및 민감도와 특

이도 연구. Communication science \& disorders, 25(1), 1-13.

김영태, 신문자, 김수진, 하지완(2020). 우리말 조음·음운평가 2. 서울: 학지사.

김우리, 고혜정(2014). 한국의 읽기학습장애 진단모형 별 진단 절차 및 준거. 아시아교육연구, 15(2), 83-110.

나경은, 서유진(2013). DSM-5에서 특정학습장애 진단기준의 변화가 국내 학습장애 학생 선정에 주는 시사점. 학습장애연구, 10(3), 53-77.

박혜원(2014). 한국 비언어 지능검사 2판. 서울: 마인드프레스.

배소영, 김미배, 윤효진, 장승민(2015). 한국어 읽기검사. 서울: 학지사.

손승현, 강옥려, 김소희, 양민화(2016). 읽기장애위험군 학생들의 교육을 위한 중재반응모델(RTI) 적용 가능성 탐색: 어휘중재 적용 효과 분석을 바탕

으로. 학습장애연구, 13(1), 1-26. 
여승수(2017). 읽기 위험군 학생을 조기 선별하기 위한 보편적 선별(Universal Screening)검사의 측정학적 적합성: 교육과정중심측정(CBM)의 활용.

학습장애연구, 14(3), 77-99.

우정한, 김요섭, 김윤옥, 강옥려, 김소희, 허승준(2016). 난독증 학생 지원 요구에 대한 이해관계자 집단 간 비교 분석. 학습장애연구, 13(1), 53-83.

유한익, 정재석, 이은경, 강성희, 박은희, 최인욱(2016). 국내 아동 및 청소년 난독증 진단을 위한 종합학습능력평가도구-읽기의 표준화 연구. 소아청소 년정신의학, 27(2), 109-118.

이대식(2017). 학습부진 관련 현행법과 국회 발의 중인 법안 분석. 학습장애연구, 14(3), 49-75.

이대식(2019). 학습 어려움, 어떻게 이해하고 대처할 것인가? 국내 학습장애 교육 발전을 위한 과제와 방향. 학습장애연구, 16(1), 1-32.

이석주, 박지훈, 이소희, 황광하, 유근창(2011). 칼라필터 렌즈(ChromaGen(TM))를 이용한 읽기능력 향상에 대한 임상연구. 한국안광학회지, 16(1), 65-74.

이애진, 이예다나(2019). 난독증 학생지원을 위한 지방자치단체 조례 분석. 특수교육학연구, 54(1), 91-119.

이애진, 양민화(2018). 교사의 학습부진, 학습장애, 일반아동 선별에 대한 근거자료 타당성 탐색: 기초학력진단평가와 표준화검사 정보를 중심으로.

학습장애연구, 15(3), 29-55.

이홍재, 김미라, 남기춘(1998). 난독증의 이해: 난독증의 분류와 평가. 한국심리학회지: 일반, 17(1), 1- 24.

정은주(2013). 'DSM-5에서의 학습장애 진단 준거의 변화가 한국 학습장애 진단 · 판별에 주는 시사점'에 대한 토론. 한국학습장애학회 춘계학술대

회토론자료집. 서울대학교, 서울.

정현승(2018). 역동적 중재반응모델이 읽기학습장애 진단율에 미치는 영향-7세 유아를 대상으로 음운인식을 결합한 파닉스 프로그램 적용- 학습장 애연구, 15(3), 231-250.

조경덕, 정재범, 남기춘(2002). 후천성 한글 난독증의 어휘처리 양상: 읽기, 명명, 쓰기 장애에 대한 사례연구를 중심으로. 언어청각장애연구, 7(3), $1-20$.

황규호(2015). 국가 교육과정 개정과 교원정책의 대응과제. 한국교원교육학회 68차 연차학술대회자료집. 한국교총, 서울.

\section{ORCID}

이은주(제1저자, 교신저자, 연구교수 https://orcid.org/0000-0003-2976-3151); 김영태(공동저자, 교수 https://orcid.org/0000-0003-1738-6862) 